
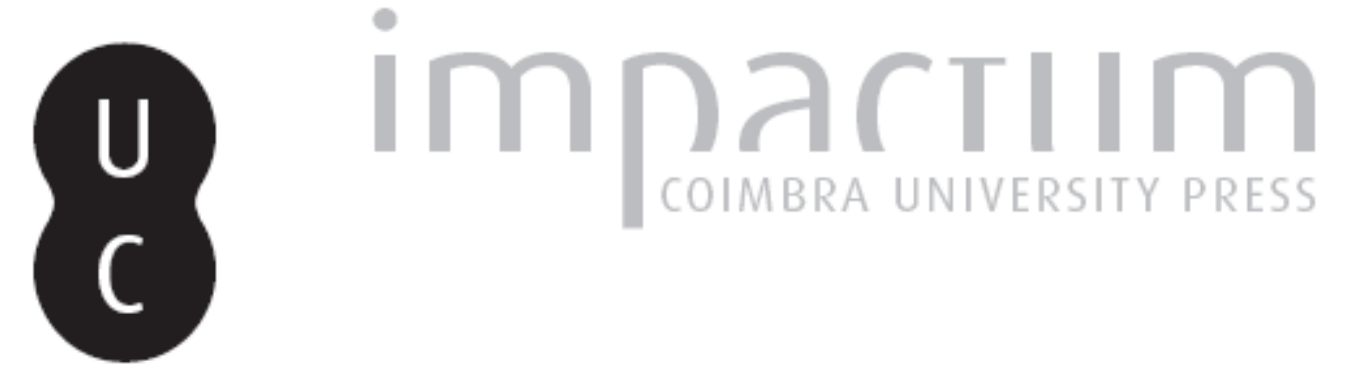

\title{
Pombal e D. Miguel da Anunciação, Bispo de Coimbra
}

Autor(es): $\quad$ Rodrigues, Manuel Augusto

Publicado por: Imprensa da Universidade de Coimbra

URL persistente:

URl:http://hdl.handle.net/10316.2/43865

DOI:

DOI:https://doi.org/10.14195/2183-8925_4-1_9

Accessed : $\quad$ 26-Apr-2023 15:01:07

A navegação consulta e descarregamento dos títulos inseridos nas Bibliotecas Digitais UC Digitalis, UC Pombalina e UC Impactum, pressupõem a aceitação plena e sem reservas dos Termos e Condições de Uso destas Bibliotecas Digitais, disponíveis em https://digitalis.uc.pt/pt-pt/termos.

Conforme exposto nos referidos Termos e Condições de Uso, o descarregamento de títulos de acesso restrito requer uma licença válida de autorização devendo o utilizador aceder ao(s) documento(s) a partir de um endereço de IP da instituição detentora da supramencionada licença.

Ao utilizador é apenas permitido o descarregamento para uso pessoal, pelo que o emprego do(s) título(s) descarregado(s) para outro fim, designadamente comercial, carece de autorização do respetivo autor ou editor da obra.

Na medida em que todas as obras da UC Digitalis se encontram protegidas pelo Código do Direito de Autor e Direitos Conexos e demais legislação aplicável, toda a cópia, parcial ou total, deste documento, nos casos em que é legalmente admitida, deverá conter ou fazer-se acompanhar por este aviso.

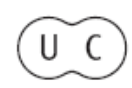




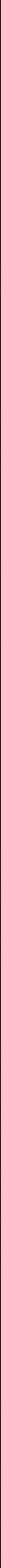


MANUEL AUGUSTO RODRIGUES

\section{POMBAL E D. MIGUEL DA ANUNCIAÇÃO, BISPO DE COIMBRA}

A decadência da Igreja na Europa, entre 1715 e 1800, período a que podemos chamar «século das luzes e da revolução francesa", é um facto assinalado pelos historiadores, de uma maneira geral. L.-J. Rogier, ao tratar deste assunto, afirma que não se pode aplicar no caso a parábola do Evangelho que fala do homem iníquio que veio semear furtivamente, durante a noite, sizânia no campo onde crescia o bom trigo. Por mais edificante que seja a parábola, ela não tem cabimento no respeitante às relações entre a fé e «as luzes». E a razão é que a situação histórica vigente não era, por um lado, a de uma comunidade fervorosa de fiéis, e do outro, um grupo de invasores audaciosos que tentavam atacar de fora, casos de Voltaire, Diderot e a Enciclopédia, d'Holbach, Helvétius, La Mettrie e Volney, que declaravam quimera toda a religião. E prossegue o mesmo autor: «En fait, ces hommes sont issus de cette collectivité; ils ont grandi dans son atmosphère: tous sont éléves des jésuites. Ils n'ont donc pas assailli par surprise la communauté chrétienne du XVIII ${ }^{e}$ siècle; ils en provenaient et pouvaient se croire interprètesn! ( $\left.{ }^{1}\right)$.

Não foram os livros, pura e simplesmente, que descristianizaram a França e os outros países europeus: «la déchristianisation a seulement pris forme dans ces livres, mais ce qui apairaissait ainsi en pleine lumière s'était propagé depuis longtemps déjà dans l'ombre». Já antes, mesmo desde o fim do séc. XVII, era perceptível um resfriamento progressivo da

* Faculdade de Letras da Universidade de Coimbra.

(1) Cf. L.-J. Rogier, in Nouvelle Histoire de l'Église, vol. IV (Siècle des Lumières, Révolutions, Restauration), ed. por L.-J. Rogier, R. Aubert, M. D. Knowles, Paris, 1966, p. 9 e sgs. 
vida religiosa. No séc. XVIII para muitas pessoas, diz Rogier, a religião era assunto não tanto de convicção mas sim de submissão às forças conjuntas do Estado e da Igreja, e de conformidade a um conjunto de tradições, de regras e de convenções que impediam a ruptura do equilíbrio social.

Passadas na França as tempestades provocadas pelo galicanismo, pelo jansenismo e pelo quietismo, criara-se no reinado de Luís XIV um espírito que se pode definir de "une fronde d'austerité dans la foi», incarnada na pessoa de Madame de Maintenon, graças a quem a corte se transformou num "grande, triste convento penitencial». Ela era "a sabedoria e a devoção".

A sociedade cristã da época caracterizava-se por um grande sentido de rigidez no campo da moral, pelo medo do contacto com a esfera do sagrado, pela exigência tremenda de admissão aos sacramentos. A separação radical entre o mundo divino e o mundo profano era evidente. E em tudo o que se passava na esfera religiosa fácil era o cair-se na hipocrisia da vivência religiosa e numa prática cristã pouco sólida e sem conviç̧ão. $O$ que não quer dizer que não se devam referir também certos aspectos positivos, como o combate à bruxaria que, em nome da ortodoxia, tinha dado origem a inúmeras crueldades.

Foi na Inglaterra, França e Províncias Unidas dos Países Baixos que a evolução cultural se fez sentir de forma mais acentuada. A Alemanha, salvo o caso de Leibniz, só na segunda metade do séc. XVIII veio a ocupar um lugar relevante. O surto verificado no domínio das ciências naturais e as novas orientações filosóficas contrastavam, por outro lado, com o absolutismo que, com o seu dirigismo cultural e religioso, tornava quase impossível uma liberdade de pesquisa científica e de irradiação cultural normais. A Holanda constituiu um caso especial em todo este processo pelo que toca ao clima de tolerância religiosa criado, por razões de ordem pecur liar. Lá os filósofos de França e de Inglaterra podiam livremente expor as suas ideias com toda a abertura. Locke e Bayle encontraram-se em Roterdão; e em Amsterdão imprimiram-se sem dificuldade obras que noutros países seria impossível dar à estampa. A predominância política e social da burguesia muito contribuiu para esse espírito de tolerância que caracterizou a história da Holanda daquele tempo.

Mas o que não oferece contestação é o facto de se ter desenvolvido bastante por toda a parte um enorme interesse pelos problemas sociais, políticos, culturais e até religiosos, tendo a imprensa periódica ocupado em tudo isto um lugar de destaque bem como o convívio de salóes. Foi um período 


\section{Miguel da Anunciação}

extremamente rico em produção de obras e em discussão de problemas de vária ordem.

0 deísmo, chamado por alguns «escola superior de cepticismo», em que se evidenciaram Bayle, Collins, o Dictionnaire historique et critique (4 vols., 1695-1697) e depois a Ency. clopédie (1751-1772) vieram substituir a autoridade pela crítica, como escreve P. Hazard em A Crise do Pensamento Europeu. Negando a ligação entre religião e moral, insistindo em que o ateísmo não conduz neoessariamente à corrupção dos costumes e afirmando que uma sociedade sem fé em Deus pode ser mais virtuosa do que a dos cristãos, os novos ideólogos cussões estéreis que nada contribuíam para o progresso espiritos.

Tudo se complicava ainda mais pelo facto de, entre os eclesiásticos, não haver pensadores à altura nem investigadores de envergadura que respondessem às exigências culturais do tempo. A arma tradicional da Igreja era o anátema, a interdição que impunha o silêncio. Os teólogos perdiam-se em discussões estéreis que nada contribuíam para o progresso espiritual da Igreja. Bento XIV denunciou amargamente esse estado de coisas e Voltaire escreveu a Helvetius que o único meio de reencontrar a paz era "estrangular o último jesuíta com as tripas do último jansenista».

Tensões entre a fé e a ciência houvera-as sempre no decurso da história. Polémicas entre teólogos de várias escolas $\epsilon$ filósofos de diversos quadrantes existiram ao longo dos séculos com maior ou menor intensidade. Mas agora o problema era diferente. Perguntava-se, por exemplo, como conciliar a Providência com as descobertas científicas verificadas. A natureza parecia tudo explicar e os inventos de Descartes e de Newton e as intervenções de Pascal e de outros pensadores católicos preocupavam seriamente os espíritos. Deus era considerado presente na criação, no círculo maravilhoso do vapor e da água, na ordem do mundo. Era a prova psico-teológica da existência de Deus de forma convencional, pode dizer-se.

A Igreja ficava reduzida a uma obra de educação. $O$ pecado original e a redenção eram vistos como mitos. $\mathrm{O}$ mal e a cruz eram negados sistematicamente. $O$ optimismo impunha-se por toda a parte. A religião e a moral identificavam-se. Em tudo isto o pensamento do Toland, Tindal, Locke e outros ganhava cada vez mais adeptos. E o mesmo se diga de Voltaire, Montesquieu e Rousseau, e no campo do direito a autoridade de Grotius.

0 indiferentismo religioso, o anticlericalismo, os ataques ao dogma católico eram temas frequentes nas obras então dadas à estampa e nas discussões que se travavam um pouco 
por todo o lado. A franco-maçonaria, que era um tipo de deísmo, veio a ser condenada pela Igreja mas com pouco sucesso. $\mathrm{E}$ os soberanos usavam o seu direito de placet o que retardava imenso a promulgação dos decretos pontifícios e episcopais.

A Santa Sé no séc. XVIII apresenta uma fisionomia especial. No período da Contra-Reforma, entre o concílio de Trento e os tratados de Westfália (1648) e đos Pinenéus (1659), a Igreja tomou então as medidas necessárias para enfrentar a crise que se abatera sobre a cristandade e isso ficou a dever-se em larga medida à acção de alguns papas, como Pio V, asceta rígido, Gregório XIIII, célebre jurista, e, sobretudo, Sisto $\mathrm{V}$, que se impôs como organizador exímio.

As guerras de religião ensombraram enormemente a época que se seguiu, durante a qual se travaram duros combates entre católicos e protestantes, o que fez com que se tivesse assistido a uma das páginas mais tristes da história das Igrejas de todos os tempos.

Com os tratados acima referidos entrou em acção o princípio "cuius regio illius et religio» o que, juntamente com outras medidas tomadas pelos soberanos, levou à redução da influência da Igreja à zona do Mediterrâneo: Itália, França, Espanha, Portugal, certas regiões da Austria e da Alemanha, e Países Baixos do Sul e Polónia.

E foi então que veio ao de cima a hegemonia francesa na Europa dentro da esfera eclesiástica. Roma mal conseguia controlar a preponderância exercida pelos franceses, imbuídos, como também sucedia em Espanha, na Austria e em quase toda toda a Alemanha, de ideias absolutistas, cesaro-papistas e erastianianas.

O prestígio do papa diminuia consideravelmente e a sua autoridade mesmo em matéria de fé e costumes era contestada em pleno "século das luzes». O primado de honra era facilmente aceite pelos príncipes e pelos teólogos de Lovaina e da Sorbonne, mas o mesmo já não sucedia com o primado de jurisdição.

A medida que se afirmava o absolutismo monárquico diminuia a crença na supremacia pontifícia. Partidários e adversários da infalibilidade pontifícia e do primado de jurisdição degladiavam-se com frequência nas suas obras. Era o surgir da idade do episcopalismo. 0 que não significa falta de respeito do mundo culto civilizado pelo bispo de Roma.

Bento XIV (1740-1758) é no séc. XVIII o único papa que tenta o diálogo com a evolução cultural que se processava a passos largos pela Europa fora. Roma mantinha-se praticamente ausente desse avanço extraordinário que a inteligência realizava nos vários países do velho continente, procurando com 


\section{Miguel da Anunciação}

o anátema e outras formas negativas de reagir sufocar a evolução mental e científica que se verificava. Era uma Igreja de imagem "negativista», de costas voltadas para o progresso e o avanço cultural. Bento XIV, o papa Lambertini, surgiu como um espírito clarividente e compreensivo da situação que se vivia. Tentou melhorar as relações entre o poder temporal dos Estados e a Santa Sé, levando a cabo uma série de concordatas com vários países, entre eles Portugal. Além disso, tomou diversas medidas em ordem a reformar a vida da Igreja.

Seguiram-se-lhe Clemente XII (1758-1769), que se manteve na linha da tradição; Clemente XIV (1769-1774), que suprimiu a Companhia de Jesus pela Bula Dominus ac redemptor (1773); e Pio VI (1775-1799) que visitou José II em Viena de Austria (1782) e condenou a Constitution civile (1791), o que deu origem ao cisma na Igreja de França.

A evolução episcopaliana em França, nos Países Baixos e na Alemanha foi uma realidade que muito contribuiu para uma visão diferente das relações com Roma. Entre os autores que mais sobressairam, destacou-se Zeger Bernard van Espen (1646-1728), o pai do jansenismo jurídico, verdadeiro episcopalismo radical que, conhecendo bem a história da antiguidade cristã, veio a concluir pelo primado pontifício de honra e pelo conciliarismo. Escreveu o célebre Jus ecclesiasticum (1700) que foi reeditado várias vezes e se tornou a bíblia dos episcopalianos e o ponto de partida do febronianismo em toda a Europa.

$\mathrm{Na}$ Alemanha, devido ao richerismo e ao jansenismo, salientou-se Nikolaus von Hontheim (1701-1790), que frequentara em Lovaina os cursos de Van Espen e escreveu o famoso tratado De statu Ecclesiae et legitima potestate Romani Pontificis, em 1763, sob o pseudónimo de Justinus Febronius. 0 sub-título ad reuniendos dissidentes in religione christianos é de si sugestivo. A obra teve bastante eco nos países latinos, dela se tendo feito edições e traduções em francês, espanhol e português. Os ataques à Companhia de Jesus e à Cúria Romana são frequentes na obra de Febronius bem como a apologia dos direitos das igrejas nacionais. $\mathrm{O}$ elo entre o direito natural e o absolutismo de Estado é uma ideia importante no referido tratado, cujas consequências se revestiram de enorme importância.

Quanto à vida interna da Igreja, há a salientar a enorme influência dos jesuítas que detinham o monopólio do ensino $\epsilon$ da pregação. Tendo exercido uma acção altamente positiva durante muito tempo, vieram depois a cair em exageros de vária ordem, sendo mesmo criticados pelas outras ordens reli- 
giosas, em especial por aquelas que, na Idade Média, haviam desenvolvido uma notável acção de evangelização e desenvolvimento cultural e social.

Tendo apostado no absolutismo de Estado, opondo-se a qualquer ideia próxima da democracia, os jesuítas seriam depois vítimas fatais do poder régio. Em Portugal a expulsão em 1759 foi um acontecimento de repercussões enormes, desencadeando depois um processo idêntico em Espanha (1767) até culminar com a extinção, em 1773, por Clemente XIV. A influência do jurista espanhol Rafael Macanaz em Sebastião José de Carvalho e Melo e no ministro Aranda foi extraordinária. A destruição da Companhia de Jesus é um dos factos mais desagradáveis da história moderna, escreve Rogier, que diz ainda: "Il en résulta une grande désorganisation, la destruction de plus de six cents maisons, l'expulsion d'environ vingt mille religieux, dont plus de la moitié étaient prêtres, la fermeture de quelques centaines d'écoles, l'abandon de territoires de mission tout entiers: malgré cela, il ne faut pas la repprésenter comme un scandale. Des déficientes très réelles avaient irréparablement sapé alors le crédit de la Compagnie. Le désastreux fut la servilité avec laquelle le pape exécutait ce qui lui imposaient les puissances séculières" $\left({ }^{2}\right)$.

A prática religiosa deste período não se caracterizava por um grande henoismo nem por um fervor exemplar. $\mathbf{O}$ quietismo, o jansenismo e o laxismo tinham criado um estado de desorientação bastante acentuado. A mediocridade e a indiferença tinham-se instalado na vida religiosa, devendo contudo abrir-se uma excepcão para os trapistas, os redentoristas, os espiritanos, os passionistas e os monfortinhos que se impuseram como frades de elevado mérito.

No campo científico, artístico e literário a estagnação era flagrante. Tirando à parte Calmet $(+1757)$, ilustre exegeta, Mabillon, Orsi, Florez e outros evidenciaram-se no domínio da história da Igreja. Rareiam as obras de carácter apologético e polémico e os livros de devoção não atingem o nível dos séculos anteriores. Foi anti-místico o séc. XVIII, no dizer de um historiador.

$\mathrm{Na}$ segunda metade do séc. XVIII apareceram várias sociedades secretas, como a Amicizia cristiana, em 1788, em Tu. rim, Viena e noutras cidades europeias. Entre o povo cristão teve então grande voga a devoção ao Santíssimo Sacramento, ıे Virgem Maria e ao Sagrado Coração de Jesus.

( $\left.{ }^{2}\right)$ ID., Ibid., p. 122. 


\section{Miguel da Anunciação}

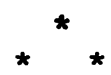

Em 8 de Dezembro de 1768 expedia D. Miguel da Anunciação, bispo de Coimbra desde 1741, uma pastoral, em que apontava aos seus diooesanos certos livros de cuja leitura deviam abster-se por serem considerados perniciosos. Entre os professores e estudantes da Universidade de Coimbra andavam por aquele tempo muito em voga obras contendo doutrinas contrárias aos ensinamentos da Igreja Católica, como se lê na Pastoral. Entre eles contavam-se alguns dos mais notáveis escritores, como Voltaire e Rousseau. Essa pastoral viria a ser o ponto de partida para uma dura perseguição movida ao bispo de Coimbra. Nunca foi impressa, havendo dela várias cópias, com uma ou outra variante, mas sem importância. E acerca desse documento e da censura que a Real Mesa Censória lhe impôs que iremos, essencialmente, tratar neste estudo.

Mas antes vejamos, ainda que em traços largos, a biografia de D. Miguel da Anunciação, que se chamava antes de abraçar a vida religiosa Miguel Carlos da Cunha. Nasceu em Lisboa a 28 de Fevereiro de 1703, filho do primeiro conde de Povolide, Tristão da Cunha de Ataíde e Melo, e de D. ${ }^{a}$ Ãngela Maria de Távora, filha do segundo conde de S. Vicente, Miguel Carlos de Távora $\left({ }^{3}\right)$. Foi porcionista do Colégio de S. Paulo de Coimbra $\left({ }^{4}\right)$ e estudou Cânones na Universidade de Coimbra, tendo obtido o grau de doutor em 2 de Julho de $1725\left(^{5}\right)$, e estava já nomeado para lente condutário com privilégios de lente quando, tocado pela missão feita na cidade do Mondego

( $\left.{ }^{8}\right)$ Sobre D. Miguel da Anunciação, vid. Inocêncio, vol. VI, p. 217, e XVII, p. 36; Fortunato de Almeida, História da Igreja em Portugal, nova ed., 1967-1971, vol. II, pp. 608-618 (com abundante documentação); ID., «D. Miguel da "Anunciação, Bispo de Coimbra», in Revista de História, I (1912), pp. 19-28, 110-120, 162-171; vários artigos em $O$ Conimbricense e em $O$ Instituto; Grande Enciclopédia Portuguesa e Brasileira, vol. II, pp. 904-905; Dicionário de Portugal (de E. Pereira-G. Rodrigues), vol I, pp.585-587; J. Martins de Carvalho, Apontamentos para a história contemporânea, Coimbra, 1868; Fr. António Pereira da Silva, A questão do sigilismo em Portugal no século XVIII, Braga, 1964; Manuel Augusto Rodrigues, D. Miguel da Anunciação e o Cabido da Sé de Coimbra. Coimbra, 1982 (Separata do vol. V do Boletim do Arquivo da Universidade de Coimbra); Samuel J. Miller, Portugal and Rome c. 1748-1830. An Aspect of the Catholic Enlightenment, Roma, 1978.

(') Vid. Apêndice Documental (I).

(5) Ibid. (II a VIII). 
por Fr. Afonso dos Prazeres e Fr. Manuel de Deus, frades do Varatojo, resolveu seguir a vida claustral, tomando o hábito dos cónegos regrantes do mosteiro de Santa Cruz, em 26 de Abril de 1728. Estava-se então a assistir neste instituto religioso à reforma da congregação de S.to Agostinho realizada por Fr. Gaspar da Encarnação $\left.{ }^{8}\right)$.

Por aquela época a Igreja em Portugal atravessava uma crise bastante profunda. Entre outros aspectos, destaquemos apenas a questão do sigilismo que começou a lavrar pelo ano de 1744 entre os eremitas calçados de S.to Agostinho, donde passou para Santa Cruz e daqui para outros mosteiros e conventos $\left(^{7}\right)$. Os religiosos que transigiram com a imposição de seus superiores constituiram seitas e tomaram o nome de "sigilistas», por violação do segredo da confissão, e mais especialmente "jacobeus», por haver na sala onde realizavam as suas reuniões um quadro representando a escada de Jacob, alusão ao livro do Génesis.

Em 1737 foi Miguel da Anunciação eleito geral da congregação de Santa Cruz e em 1738 nomeado bispo de Coimbra pelo rei D. João V. A sagração e tomada de posse tiveram lugar em 1741. Iniciava-se assim uma governação pastoral altamente positiva para a vida religiosa da diocese, apesar de, pelo meio, terem surgido problemas vários que agitaram profundamente a serenidade de actuação de $\mathrm{D}$. Miguel na promoção da vida eclesiástica diocesana. As muitas visitas pastorais realizadas pelo ilustre prelado conimbricense, a criação da Acade-

(') Fr. Gaspar da Encarnação (Gaspar Moscoso da Silva), doutorou-se em Cânones pela Universidade de Coimbra no dia 3 de Maio de 1708 (A. U. C., Autos e Graus, vol. 53 (1707-1710), fl. 33 v. ${ }^{\circ}$ ).

Nasceu em Lisboa a 17 de Maio de 1685 , filho do $5 .^{\circ}$ conde de Santa Cruz e irmão do $3 .^{\circ}$ marquês de Gouveia. Foi deão da Sé de Lisboa, deputado do Santo Ofício e do Conselho de D. João V. Em 1710 foi nomeado reitor da Universidade, sendo em 1713 reconduzido no dito cargo, "com o título, preeminência e emolumentos de reformador». Em 1715 recolheu ao Convento do Varatojo, onde professou, acto a que assistiu D. João V e a corte. Veio depois a ser refomador da Congregação dos Cónegos regrantes de Santo Agostinho. Morto o Cardeal Motta e Silva, o rei «magnânimo» nomeou-o ministro do seu gabinete, não tendo sido fecunda a sua actividade política. Protegeu bastante a família por causa, especialmente, da Casa de Aveiro. Falecido D. João V, foi dispensado do cargo político que ocupava. Morreu em 25 de Novembro de 1754.

(') Sobre o sigilismo, vid. Fr. António Pereira da Silva, op. cit.; L. Cabral Moncada, Mística e Racionalismo em Portugal no séc. XVIII, Coimbra, 1952 - Sobre a Jacobeia, vid. art. de Fr. António Pereira da Silva, in Verbo. Enciclopédia Luso-Brasileira de Cultura, vol. II, cols. 267-269 (com bibliografia). 


\section{Miguel da Anunciação}

mia Litúrgica $\left(^{8}\right)$ do Seminário diocesano, para o qual procurou logo encontrar um corpo dirigente dinâmico, de que era reitor o italiano Nicolau Giliberti, e no qual pensou logo insti-. tuir uma biblioteca bem apetrechada de obras antigas e modernas, a preocupação de revitalizar a pastoral nas diversas paróquias do bispado (ao tempo dividido em três arcediagados: Vouga, Ceia e Penela) que visitou amiúde - eis algumas facetas importantes da acção de D. Miguel da Anunciação. Bastava a criação do Seminário de Coimbra, cujas obras se iniciaram em 1748 e terminaram em 1765 para imortalizar a memória desta personalidade $\left({ }^{8}\right)$. Contou aquela instituição com professores de grande craveira intelectual, como foi o caso do Dr. Jerónimo Soares Barbosa $\left({ }^{10}\right)$.

(8) A Academia Litúrgica Pontifícia criada em 1747 no mosteiro de Santa Cruz pelo papa Bento XIV, tinha como escopo propagar e facilitar o ensino dos sagrados ritos e da história eclesiástica. Dependia directamente do papa, sendo a sua direcção confiada ao então bispo de Coimbra, D. Miguel da Anunciação. Manteve estreita relação com a Academia dos Sagrados Ritos e História Eclesiástica esabelecida em Roma pelo papa Bento XIV. Em 1758 D. Miguel publicou desenvolvidos estatutos da Academia por ele mesmo elaborados. Segundo consta, o papa tinha em tanto apreço as actividades da Academia que lhe ofereceu o seu busto de mármore, o manuscrito da sua obra Sínodo Diocesano, a escrevaninha de que serviu no Concílio de Trento e uma colecção das suas obras, em 12 volumes, em cujo frontespício escreveu de seu próprio punho: «Ad usum, Academiae Liturgiae Conimbricensis». D. Miguel dotou a Academia de tipografia propria, onde eram impressos os trabalhos e comunicações dos seus membros. Em 1767 o marquês de Pombal extinguiu-a. Existem impressas duas comunicações feitas na Academia de Liturgia por D. Miguel: «Utrum lapidea ligneave querint; vel oporteat esse, et consecrata» e «Le pane, quo usus est Christus Dominus quando in ultima Coena Eucharistiam instituit atque primam Liturgiam celebravit: Azimusne querit; an Fermentatus?»

( ${ }^{\circ}$ Vid. Apêndice Documental (IX) sobre a história do Seminário de Coimbra no tempo de $\mathrm{D}$. Miguel da Anunciação e as visitações da diocese.

$\left({ }^{10}\right)$ Jerónimo Soares Barbosa, presbítero secular, bacharel formado em Cânones pela Universidade de Coimbra, foi professor de Retórica e de Eloquência no Colégio das Artes. Natural de Ancião, onde nasceu a 24 de Janeirode 1737, veio a falecer a 5 de Janeiro de 1816. Era irmão mais novo de. António Soares Barbosa, também sacerdote secular. Educado no Seminário de Coimbra, criado havia pouco tempo por D. Miguel da Anunciação, recebeu a ordenação sacerdotal em 1762. Em 1766 foi nomeado professor de Retórica e de Poética. Tomou o grau de bacharel em Cânones em 21 de Julho de 1768. No ano seguinte entrou para a Academia Real das Ciências de Lisboa, sendo promovido à categoria de sócio livre em 30 de Novembro de 1803 . Jubilou na cadeira de Retórica em 23 de Fevereiro de 1790. Foi visitador 
Em 1768 foi levado preso para Pedrouços por causa da pastoral anteriormente referida, voltou para a sua diocese em 1777 depois de ter passado 8 anos no forte de Pedrouços. Foi solene a entrada de D. Miguel em Coimbra como se depreende do texto que apresentamos em apêndice ${ }^{(11)}$. Em todo o processo acusatório teve um papel especial o Cónego Luís de Melo, natural de Ansião, ordenado sacerdote em 1738, que também em questōes relativa ao Cabido diocesano se revelou de uma agressividade particular para com os seus colegas, nomeadamente no concernente ao problema das meias-conezias

de primeiras letras e língua latina da provedoria de Coimbra, por nomeação de 8 de Julho de 1792, sendo encarregado de promover e dirigir as ediçōes dos autores clássicos para uso das escolas, por aviso de 19 de Novembro de 1793. Em 1799 foi nomeado deputado da Junta de Directoria Geral dos Estudos então criada. - Escreveu: Oratio auspicalis habita Conimbricae in Gymnasio Maximo, anno MDCCLI, Lisboa, 1767; Instituiçōes oratórias de Marco Fabio Quintiliano..., Coimbra, 2 ts., 1788 (esta obra teve segunda edição, ibid., 1836; em Paris também se publicou uma segunda edição nesse ano; e na Baía uma outra em 1829); Poetica de Horacio, Coimbra, 1791 (2. ed., Lisboa, 1815); Institutiones oratoriae M. F. Quintiliani..., Coimbra, 1786; Eschola popular das primeiras letras, Coimbra, 1796 (segundo o parecer do Dr. Rodrigues Gusmão, nesta obra lançou o autor os fundamentos sólidos do ensino das primeiras letras que se generalizou em todo o reino pela diligência da Directoria Geral dos Estudos); Do Coração de Jesus..., Lisboa, 1802; Epitome Universae Historiae, et Lusitaniae..., 2 ts., Coimbra, 1805; As duas Linguas, ou Grammatica philosophica da lingua portugueza, comparada com a latina, para ambas se aprenderem ao mesmo tempo, Coimbra, 1807 (tem no fim um catálogo de todas as obras impressas e manuscritas do autor e das de seu irmão, o Dr. António Soares Barbosa); Orationes XV, habitae in Academia Conimbricensi, et Epistolae Nuncupatoriae XX (publicadas em Jornal de Coimbra, em vários números); Grammatica philosophica da lingua portugueza..., Lisboa, 1oL2 (2. ${ }^{\mathrm{a}}$ ed., 1830); Mundo allegorico, ou o plano da religião christã (obra póstuma publicada sob a protecção do Cardeal Patriarca de Lisboa e dos Arcebispos e Bispos), Coimbra, 1857 a 1859, 3 vols.; Analyse dos Lusiadas de Luis de Camōes (obra póstuma), Coimbra, 1859; Excellencias da Eloquencia popular, compostas na lingua italiana por Luis Antonio Muratori, e traduzidas na portuguesa, Coimbra 1859. Há ainda a referir uma série de obras inéditas sobre Retórica, Gramática, etc. Acerca da Grammatica philosophica da lingua portugueza, escreve o Prof. Herculano de Carvalho: «Fundada nos princípios teóricos estabelecidos pela chamada gramática filosófica ou razoada (cuja primeira e mais conhecida representante é a famosa Gramática de Port-Royal, 1660, de Antoine Arnaut e Cl. Lancelot), S. B. realizou nela a melhor e a mais completa exposição gramatical da língua portuguesa até à sua época» (in Verbo. Enciclopédia Luso-Brasileira de Cultura, vol. 3, pp. 586-587).

(II) Vid. Apêndice Documental (X). 
(os meios Cónegos pretendiam as mesmas regalias dos Cónegos e D. Miguel viria a extinguir os primeiros) $\left({ }^{12}\right)$.

Anunciação veio a falecer em Semide, em 29 de Agosto de 1779 , tendo a sua morte sido considerada em odor de santidade por bastantes pessoas $\left({ }^{13}\right)$.

Foram várias as Pastorais escritas pelo prelado de Coimbra, o que prova o seu cuidado em velar pela difusão do Evangelho e pela promoção da vida espiritual entre os seus diocesanos. Eis algumas delas: Carta Pastoral e exhortatoria, de 15 de Agosto de 1761; a Pastoral de 26 de Agosto de 1741 regulando a comida que lhe deviam dar os párocos quando fosse em visita pastoral (reproduzida em o Conimbricense de 30 de Agosto de 1891); a Pastoral de 10 de Fevereiro de 1748 relativa à constituição do Papa sobre a bênção e indulgência plenário a aplicar aos moribundos; a Carta Circular sobre a visita pastoral de 26 de Agosto de 1761; a Pastoral com Breve inserto de Bento XIV sobre a oração mental, de 6 de Abril de 1747 (lembre-se que o tema da oração mental era um dos mais importantes apontados pelos "jacobeus"); a Pastoral com a indicação apostólica do Anno Santo, de 30 de Dezembro de 1749; a Carta Pastorad sobre os officios e exequias dos defuntos $e o$ sacramento do matrimonio, de 23 de Janeiro de 1762; a Carta Circular sobre o jejum da vigilia de S. Mathias, de 8 de Fevereiro de 1762; a Pastoral reduzindo o numero dos pecados reservados, de 3 de Janeiro de 1763; a Pastoral com o teor de uma carta ou Breve de Sua Santidade, em que declara a verdadeira intelligencia das Letras Apostolicas, em forma de Breve (sobre o sagrado jejum), de 3 de Novembro de $1745\left({ }^{14}\right)$.

( $\left.{ }^{12}\right)$ Ibid. (XI). O cónego Luís de Melo, filho de Belchior dos Reis e de Faustina de Melo foi natural de Ancião, onde nasceu em 1119. Pelo seu processo de ordenação, sabemos ainda que seus pais tinham património e que Ansião contava naquela altura 440 fogos e havia na terra 18 sacerdotes e um clérigo de ordens menores. As suas ınquirições foram feitas em 10 de Janeiro de 1738. Recebeu a ordenação sacerdotal a 10 de Janeiro de 1738 . Era pároco da freguesia D. Jerónimo da Encarnação (A.U.C., Processo de Ordenação). Formou-se em Cânones em 19 de Junho de 1739 (Ibid., Autos e Graus, vol. 73, fl. 86), sendo aprovado «nemine discrepante». Matriculando-se em «Instituta» em 1 de Outubro de 1731 (Ibid., Matrículas, vol. 49, fl. 373); Entre 1 de Outubro de 1732 e 1 de Outubro de 1738 encontramos referências a sete matrículas em Cânones (L. 50 , fl. 192; 1. 51, fl. 181; 1. 52, fl. 173; l. 53 , fl. 180 ; l. 54 , fl. 180 ; 1. 55, fl. 190 ; e l. 56, fl. 175). relatos.

( $\left.{ }^{13}\right)$ Ibid. (XII). Do seu falecimento e funerais existem vários

${ }^{(4)}$ Ibid. (XIII). Escreveu ainda um catecismo de doutrina cristã e em missal para uso dos fiéis. 


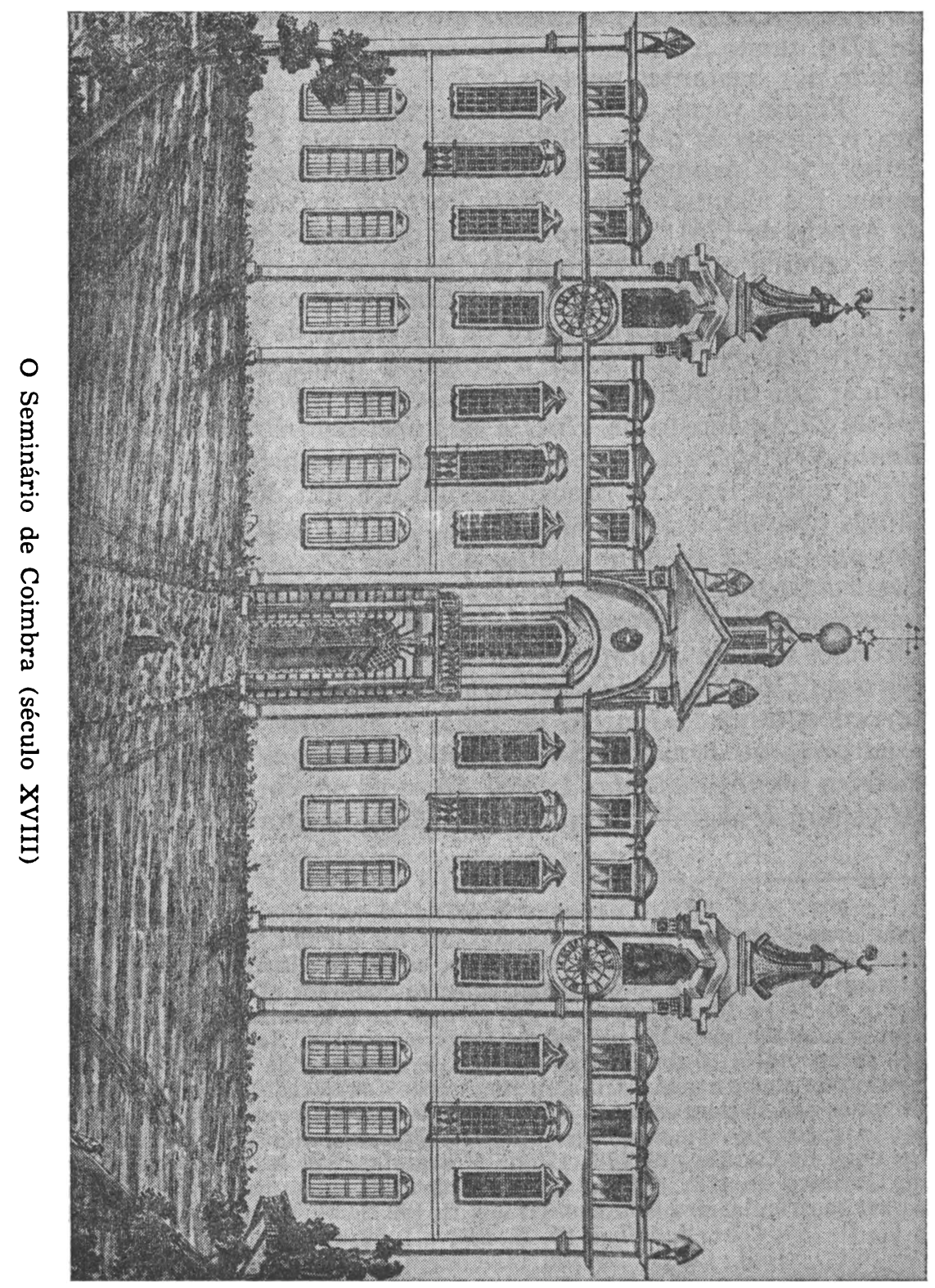




\section{Miguel da Anunciação}

Em S. Martinho do Bispo teve o bispo, segundo consta ( $\left.{ }^{15}\right)$ uma tipografia clandestina na qual foi impressa uma obra cuja autoria lhe é atribuída: Fundamentos que certas pessoas doutas, sendo perguntadas, offerecerão aos srs. arcebispos e bispos de Portugal, em defesa da sua jurisdição ordinaria, os quaes fôram apresentados a Sua Santidade, pelos procuradores dos excellentissimos e reverendissimos prellados, $e$ agora dados ao prelo por Pedro Bembo Minniccss, para que a todos constem as justificadissimas razoens, que suas Excellencias tiverão para recorrerem a Sua Santidade, e para os mais procedimentos, que fizerão sobre o Ponto da interrogação dos Complices aos penitentes no acto da Confissão Sacramental (Madrid, 1746, na Officina dos herdeyros de Francisco del Hierro) $\left({ }^{16}\right)$.A indicação de Madrid foi como a de Roma, que trazem as Letras Apostolicas, ambas falsas, para ocultar os trabalhos de D. Miguel da Anunciação, segundo se pensa.

Pedro Bembo, que é apresentado como o autor da obra, foi o célebre cardeal e humanista italiano, nascido em Veneza em 1440 e falecido em Roma em 1547. Possuidor de uma excelente formação em cultura grega e latina, tomou o hábito eclesiástico e viveu na corte de Afonso d'Este. Em 1513 tornou-se secretário do papa Leão X e em 1521 retirourse para Pádua, onde vivia sua amiga Morosina. Formou uma rica biblioteca e uma colecção de antiguidades preciosa até que em 1529 era nomeado historiógrafo de Veneza e bibliotecário de S. Marcos. Paulo III, em 1539, fê-lo cardeal, recebendo então a ordenação sacerdotal. Passou depois a dedicar-se intensamente ao estudo da Sagrada Escritura e dos Santos Padres. Revelou-se exímio latinista e modelo da língua italiana. Deve-se-lhe uma história de Veneza (de 1487 a 1537), intitulada Rerum Veneticarum libri XII, publicada em 1551, e depois traduzida por ele para italiano com o nome de Historia Veneta. Escreveu ainda Le Prose, tratado da língua toscana; Cartas, muitas delas bastante curiosas para conhecer a história do seu tempo, etc. As suas obras completas vieram a ser publicadas em Veneza em 1729.

Foi este ilustre humanista que se escolheu como pseudónimo do autor dos Fundamentos..., obra que, logo no início, pergunta: "Se os Editaes, que o Santo Officio mandou publicar, em que ordena que as pessoas, a quem algum Confessor perguntar pelo Complice, ou disso tiverem noticia vão denunciar no mesmo Tribunal, contém ponto, que seja concernente

('5) Cf. J. Martins de Carvalho, op. cit.

(') Existe na B.G.U.C., Miscelâneas, vol. CCXLIII, 4056. 
à sua Jurisdição, ou se nelles se descobre alguma incompetencia, nullidade, ou injustiça? E se no caso de ser o Santo Officio incompetente para processar este delicto, pódem os Excellentissimos, e Revenendissimos Senhores Arcebispos, e Bispos deste Reyno tollerar em consciencia esta usurpação, ou se estão obrigados defender, e reintegrar a sua Jurisdição sub peccato mortali».

Ao longo de 146 pontos o tratado pretende demonstrar que a Inquisição nada tem a ver com o assunto. $\mathrm{O} \mathrm{n} .^{\circ} 1$ chama a atenção para os tópicos que depois serão desenvolvidos no decorrer da obra: se pertence à jurisdição do Santo Ofício este delito; se havia a certeza ou probabilidade da introdução de perguntar pelos cúmplices em todos os casos; se a pergunta do cúmplice é inequivocamente doutrina errónea, escandalosa e temerária, de modo que por essa razão possa pertencer a sua punição ao Santo Ofício; se este pcdia cbrigar o penitente com pena de excomunhão a denunciar o confessor que lhe perguntou pelo cúmplice do seu pecado; se nos Editais se contém injustiça ou nulidade que desobrigue o penitente da obrigação de denunciar; se os arcebispos e bispos podem consentir em consciência na usurpação da sua jurisdição cu se estão obrigados a defendê-la sub peccato mortali.

Basta atender à resposta dada ao primeiro dos referidos tópicos para logo se ver a argumentação seguida no decurso do tratado: "Respondese negativamente, porque o Tribunal do Santo Officio, só tem Jurisdição para conhecer dos crimes de heresia, ou suspeita della e fóra desta, só pódem conhecer de alguns casos, que expressamente lhe são delegados pela Sé Apostólica, como dizia Pignatel. tom. 7. consult. 54 n. 6.7.8. E por esta fórma conhecem dos casos de Poligamia. da Sodomia, e da Solicitação: $E$ como se não mostrará Constituição alguma Apostolica por onde conste cometer-se-lhe o conherimento do crime; que resulta aos Confessores de perguntarem indevidamente pelo Complice no acto da Confissão, fica indubitavel, que tal caso não pertence por titulo, ou direito algu:m à Jurisdição do Santo Officio».

Provando, a partir de textos de autores consagrados, que não podia haver certeza ou probabilidade da introdução de perguntar pelos cúmplices e que a pergunta feita a estes não se pode considerar doutrina errónea, escandalosa e temerária de forma a ser colocada sob a alçada do Santo Ofício; e que o Santo Ofício não pode, sob pena de excomunhão, obrigar o penitente que denunciasse o confessor que lhe tivesse perguntado pelo cúmplice do seu pecado, passa a tratar dos editais afixados pelo Santo Ofício. Primeiro desenvolve a questão seguinte: é lícito e necessário nalguns casos perguntar pelo cúmplice $\mathrm{e}$ 


\section{Miguel da Anunciação}

negar a absolvição se o penitente não quiser declarar; segundo, que no edital de Maio de 1745 se cometeu uma espécie de atentado contra este assunto, bem como no que se lhe seguiu.

0 último ponto é uma afirmação solene de que os bispos estão obrigados em consciência e sob pecado grave de perjuro a defender e sustentar a sua jurisdição contra a usurpação que dela se faça ou intenda fazer, "porque os Bispos em quanto ao regimen dos iocezanos exercitão a Jurisdição Pontificia, por serem instituídos in partem solicitudinis a respeito do Supremo Pastor, de que recebe a Jurisdição, Petr. ad Constit. Apostol. tom. 2. Constit. 2 Innoc. III. n. 36. e esta mesma Jurisdição se obrigão os Bispos defender debaixo de juramento, que prestão no acto da sua Sagração, ut ibi: Juro honores, privilegia et authoritatem Sanctae Romanae Ecclesiae Domini Nostri Papae, et successorum praedictorum conservare, defendere, augere, et promovere curabo".

Os derradeiros números deste ponto sexto traduzem a mesma ideia: os bispos juram no acto da sua sagração não só conservar e defender tais direitos mas ainda opor-se a qualquer usurpação que dela se faça; os bispos não podem, por conseguinte, ceder o direito da jurisdição, "porque esta he a mayor, que todos os outros bens, e Direito se chama cousa de grande prejuizo...», a razão é que os bispos não são senhores da jurisdição nem do direito das suas igrejas mas somente administradores, "Custodios, e Conservadores, a que se obrigão pelo seu juramento, e assim como não pódem alienar as jurisdiçoens, da mesma sorte estão obrigados, e adstrictos a defendellas.»

Os prelados têm mesmo de dar a vida, se necessário for, para que a sua jurisdição não seja infringida. E apontam-se casos ocorridos anteiormente, como o do médico Mesquita (em 1723) e de Luís Rodrigues (em 1727), em que o Santo Ofício por vezes duvidando do âmbito das suas atribuições entregou os réus à justiça secular. $\mathrm{E}$ aponta o exemplo do arcebispo D. Miguel de Castro que se opôs terminantemente ao tribunal do Santo Ofício, ao proibir a afixação de editais nas igrejas das suas dioceses pelo que escreveu ao rei nesse sentido.

Trata-se, pois, em resumo, de uma obra que tenta fazer a apologia dos direitos episcopais contra intromissões do Santo Ofício na esfera que lhes está reservada. A conclusão é compreensível nesta ordem de ideias: «Pelo que, seguindo este grande exemplar dos Prelados da Igreja, e o de Santo Thomás de Cantuaria, e outros muitos, que não temêrão os mayores contendores, para disputar com elles sobre a usurpação da sua Jurisdição, devem os Senhores Bispos impedir, 
esta agressão, ou espolio, que lhe tem feyto da Jurisdição, que lhe compete no caso da presente controversia: e por conservar a paz, não devem dissimular os estimulos da consciencia, em ponto tão grave, conforme o dictame do grande Doutor, e Pontificie da Igreja S. Gregorio...»

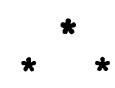

Mas o que sem dúvida alguma tornou mais conhecida a personalidade de D. Miguel da Anunciação foi a publicação de uma Pastoral, em 8 de Novembro de 1768, na qual condenava a leitura de certos livros que considerava perigosos para a religião e formação dos fiéis. Foi esse documento que nunca chegou a ser impresso (ao que se saiba )o pretexto para a sua prisão e motivou uma severa condenação da Real Mesa Censória $\left.{ }^{17}\right)$.

No início justifica a posição assumida. Sente a obrigação indispensável de guardar o depósito da revelação e sabe que "o homem inimigo não cessa de sobresemear a sizánia dos es. criptos perversos e escandalosos entre o bom trigo dos dogmas da fé, das máximas do Evangelho e da moral de Jesus Christo". Refere-se, certamente, ao facto de, entre professores e estudantes da Universidade de Coimbra, andarem em voga certas obras de escritores franceses do séc. XVIII. Julgou, pois, seu dever opor-se "como muro a esta torrente inundante de doutrinas várias e peregrinas, que se teem derramado nesta cidade e tememos passem a toda a diocese, com prejuizo immenso das almas e das consciéncias". Essas "obras das trevas» contêm muitas proposições contrárias à pureza da fé e à santidade da lei, e são "inteiramente corruptas e corruptoras da religião cristã, da disciplina e da piedade, e capazes de introduzir a abominação no logar santo, que é a Igreja». A propósito, cita S. Paulo: «Denunciamus autem vobis fratres in nomine Domini nostri Iesu Christi, ut subtrahatis vos ab omni fratre ambulante inordinate, et non secundum traditionem, quam acceperunt a nobis« ( 2 Tes. 3,6 ), que ele traduziu livremente assim: «... que nos separemos de todo o irmão que anda desordenado e não vive conforme os dictames da pura e santa doutrina». O sentido é o mesmo como se vê pelo original grego $\left.{ }^{18}\right)$.

( $\left.{ }^{17}\right)$ Vid. Apêndice Documental. (XII).

${ }^{18}$ E pela tradução da Vulgata. 
O seu conselho é que se evitem essas leituras de autores «que persuadem com maior efficacia, por meio de textos artificiosamente applicados, de razões apparentes e da força ou suavidade do estylo, as abominações, os erros e as mentiras». São livros elaborados contra a religião revelada, contra a pureza dos costumes, contra a obediência devida aos soberanos ... que devem ser evitados "como peste». Por estas linguagens apercebemo-nos facilmente da mentalidade de D. Miguel quanto às novas correntes filosófico-culturais do tempo. Segue-se a lista dos livros que ele considera perigosos: $L^{\prime} E S$ pion dans les cours des Princes chrétiens, ou Lettres et Mémoires d'un Envoyé secret de la Porte dans les cours de l'Europe; Lettres cabalistiques; Lettres chinoises; Lettres juives; Lettres sur la religion essentielle à l'homme; Oeuvres du philosophe Sanssouci; Tableau du siècle; Encyclopédie ou Dictionnaire raisonné des sciences, des arts et des métiers; De l'Esprit; L'Espion de Thomas Kouli-Kan dans les cours de l'Europe; Le contract social; La philosophie de l'histoire; Discours sur l'inéqualité des hommes, de Rousseau; Dictionnaire Philosophique; La philosophie de l'histoire; Abrégé de l'histoire; Essai sur l'histoire; L'Henriade; Précis de l'Ecclésiaste et du Cantique; L'Esprit; Le despotisme oriental; De antiquae Ecclesiae disciplina e Dissertationes historicae (de Du Pin); De statu Ecclesiae et legitima potestate Romani Pontificis (de Justino Febrónio); La Pucelle d'Orléans (de Voltaire); Belisaire (de Marmontel, da Academia Francesa).

E tece a seguir esta consideração: trata-se de autores que procuram arrancar dos corações dos fiéis "pela raíz as regras puras dos costumes, a doutrina mais sã da lei, os ditames mais sólidos da moral, e introduzir o indifferentismo e fanatismo, capazes de fazer que muitos naufraguem na fé». Além disso, põem em risco "as preciosas vidas do rei e dos príncipes e tentam alterar a boa harmonia que deve haver entre o sacerdócio e o império". Cita a propósito Isidoro Pelusiota, autor do séc. III-IV que escreveu cerca de 3.000 cartas das quais se conservam uma 2.000 que tratam de temas relativos à vida do clero e dos monges, à ascese, mística e moral, e a questões cristológicas $\left({ }^{19}\right)$. A frase que transcreve deste autor é a seguinte: «Ex sacerdotio et regno rerum administratio con. flata est; quamvis enim permagna differentia sit, ad unum tamen et unicum finem tendunt, hoc est, ad animarum salutem».

( $\left.{ }^{10}\right)$ Sobre Isidoro Pelusiota, vid. Lexicon für Theologie und Kirche, vol. V, 789 . 
Classifica tais autores como sacrílegos e temerários que tentam iludir os homens com vãs imagens "de uma especiosa philosophia" e corromper a adolescência, "ou menos radicada na fé, ou menos instruída na moral, ou menos firme nos caminhos do Senhor, e por consequéncia mais susceptível das impressões do erro e do engano». São "apóstolos da mentira" que "têm causado na cidade santa maior ruína que os gentios nos primeiros séculos e nos seguintes os hereges". E que aquela guerra, escreve, era preferível à paz de que agora goza a Igreja, "porque aquella guerra coroava os mártyres, multiplicava os fieis e a banhava de contentamento e alegria; e esta paz representa à mesma Igreja objectos tristes em muitos dos seus filhos iníquios (noutra cópia lê-se: «e muitos dos seus faz iníquos") e zelosos da impiedade. São como caçadores do inferno, armam laços à innocencia e redes à piedade, pelo que se lhes aplica o dito de Jeremias: "Inventi sunt in populo meo impii insidiantes quasi aucupes laqueos ponentes, et pedicas ad capiendas viros", que se encontra no cap. 5, ver. 26 do livro daquele profeta.

Mais os classifica de falsos profetas que não atiram por terra os altares, e não arrancam a vida corporal aos fiéis com ferro, mas impedem que se adore o verdadeiro Deus, que deve ser adorado em espírito e verdade, e privam os fiéis "com o veneno da sua ciência» («ou, para melhor dizermos, da sua ignorância») de outra vida mais nobre, que é a do espírito, alterando a sua fé, pervertendo os seus costumes, levantando nesciamente a sua soberba contra a doutrina e sciencia de Deus". Preferem o nome de filósofos ao de cristãos, tratam como superstição a fiel observância da lei e os verdadeiros cristãos como insensatos ou menos iluminados.

O parágrafo seguinte é mais um duro ataque aos filósofos franceses do séc. XVIII. Fingindo um deus cego, sem providência, sem discernimento, sem justiça na distribuição de prémios e dos castigos, fabricam um Deus «que põem em templos excelsos». Confundem a unidade do ministério sagrado, pontos de mera disciplina com verdades da fé e da moral, direitos com puros factos, os poderes do sacerdócio e do império com a dissimulada desordem entre ambos. Colocam no mesmo plano as seitas "mais abomináveis» com a religião cristã, "como se fosse compatível e conviesse a luz com as trevas, o templo de Deus com o ídolo de Belial». Citando Lactâncio, diz que acabam por ser vítimas dos seus erros: "Hoc est enim mendaciorum natura, ut cohaerere non possint».

E vem finalmente a parte relativa a sanções para quem ideia ou ouça ler tais livros. A imposição de penas, o "nervo da disciplina e a barreira da iniquidade» é uma obrigação que 


\section{Miguel da Anunciação}

se sente levado a aplicar. Não sendo permitido ler livros proibidos, as referidas obras entram nessa categoria «ipso facto». Devem os fiéis fugir delas como da peste («de lição tão contagiosa e nociva"). Os confessores devem suspender ou adiar a absolvição aos penitentes que tiverem incorrido em tal falta. O teor da pastoral é "voz de Deus», que proibe a leitura de "tão perniciosos escriptos, ainda mais funestos que as letras de Urias $\left({ }^{20}\right)$.

Outras reminiscências bíblicas aparecem na parte final da Pastoral. Os cristãos encontram-se já na Terra Santa(a Igreja), não necesitando de recorrer às águas do Egipto que são turvas; em Galaad não faltou médico e resina, como se lê em Jeremias: "Ascende in Gallad, et tolle resinam, virgo filia Aegypti; frustra multiplicas medicamina, sanitas non erit tibi" (trata-se dum vaticínio contra o Egipto). Para concluir: "Correi a beber na fonte, da qual mana a água da vida eterna; que remos dizer a escriptura e tradição, os Santos Padres e os concilios; e acautelai-vos d'aquellas cisternas arruinadas, para não beberdes a morte nas águas venenosas e corruptas».

Não pode remeter-se ao silêncio nem dissimular a verdade do Evangelho mas sim sente-se obrigado pelo seu ofício de bispo a anunciar o verdadeiro caminho. E termina a Pastoral com mais uma citação de Jeremias que denunciava os erros dos falsos profetas: "Quomodo dicitis: Sapientes nos sumus, et lex Domini nobiscum est? Vere mendacium operatus est stylus mendax scribarum. Confusi sunt sapientes (falta: «Perterriti et capti sunt); verbum enim Domini proiecerunt, et sapientia nulla est in eis» (Jer. 8, 8).

Como escreve Fortunato de Almeida: «A publicação d'esta pastoral nas igrejas levantou grande celeuma contra o bispo. Pretendia-se que por aquella forma elle se revoltava contra a auctoridade real, invadindo as attribuições da Real Mesa Censória, a quem incumbia o exame e censura dos livros; e que assim procedia como instrumento dos padres jesuitas. Não tardou que o marquês de Pombal mandasse prender o bispo e fazer uma devassa" $\left({ }^{21}\right)$. E o que passamos a ver.

Em 23 de Dezembro do mesmo ano de 1768 era dado o parecer da Real Mesa Censória que veio a ser impresso na oficina de António Rodrigues Galhardo, impressor da Real Mesa Censória. $O$ título é já de si sugestivo: "Sentença da Real Meza Censoria, contra a Pastoral manuscripta e datada de 8 de Novembro proximo passado, que o Bipo de Coimbra, D. Miguel

$\left({ }^{20}\right)$ Vid. 2 Sam., c. 11.

(21) Cf. Fortunato de Almeida, art. cit. 
da Anunciação espalhou clandestinamente pelos parocos da sua diocese, proferida no dia 23 de Dezembro de 1768" $\left({ }^{22}\right)$. Os deputados encarregados de analisar o documento de D. Miguel foram o desembargador João Pereira Ramos (irmão de D. Francisco de Lemos de Faria Pereira Coutinho), D. Fr. Manuel do Cenáculo (futuro arcebispo de Evora e que prezou nas solenes exéquias realizadas em Lisboa por ocasião da morte de D. Farncisco de Lemos, em 18222) e Fr. Inácio de S. Caetano nomeados pelo rei em 9 de Dezembro. Tudo se passou com uma enorme celeridade, como se vê. De 8 de Novembro até à impressão da sentença decorreram escassos dois meses.

Logo a começar dizem os censores que o espírito e a letra da Pastoral se assemelham às "originaes maquinaçoens» que os jesuítas fizeram a D. Afonso VI, antes e depois de ser rei, pelo que se pode ver comparando as divisões X e XI da Deducçâo Chronologica e Analytica com o que na Pastoral se escreve. As "maquinaçoens» consistem em três estratagemas: «escandecer as imaginaçoens dos povos com suggestoens e exhortaçoens pateticas compostas de expressoens eccleziasticas tão pias no modo como dolozas na substancia»; o facto de "inventarem e diffundirem calumnias infamatorias contra a real pessoa e governo" de D. Afonso, "suppondo e fingindo para isso, factos que nunca havião existido»; e o "espalharem declamaçoens sinistras pelos que illudião nos pulpitos e nos confessionarios, de que o Reino estava perdido e os vassalos delle arruinados", quando afinal o que sucedia era que o que se via «com as luzes da razão, erão batalhas ganhadas nas fronteiras do Reino, por hum gloriozo exercito, aprestos e provimentos consideraveis de armadas navaes, restauraçoens de Estados nos Dominios Ultramarinos, opulentas carregaçoens de importantes mercadorias, que delles se transportavão para enriquecerem este Reino". Os jesuítas (e o bispo) como "calumniadones e maquinadores" só falavam de "imagens tristes de infortunios e desgraças, que não havião succedido, prognosticos e temores funestos e vaons, armados no ar da malicia dos que os inventarão e embustes espirituaes ordenados ao fim de concitarem e fazerem grassar o fanatismo».

Referem-se depois às quatro colunas que sustentam o Reino: as armas, as letras, o comércio e a agricultura, que nunca haviam atingido um grau tão elevado de desenvolvimento como agora, salvo nos gloriosos tempos de D. Manuel. Está-se no "século illuminado" e já não no "seculo escuro, em que os embustes dos ditos denominados Jezuitas fizerão tan-

(22) Vid. Apêndice Documental (XIV). 


\section{Miguel da Anunciação}

tos e tão horrorozos estragos». Quer dizer, o bispo, seguindo o pensamento dos padres da Companhia, não soube ou não quis reconhecer a evidência dos factos, atacando declaradamente a verdade "com o libelo diffamatorio da sobredita, rebelde, sedioza e infame Pastoral» que tentaram impor pelo fanatismo e outros artifícios. Isto é o que, dizem, transparece claramente no preâmbulo da Pastoral, onde o bispo, escrevem, utiliza «Expressoens manifestamente falsas e affectadas, no mesmo espirito juzuitico, para enganarem os pequenos, que não passão da superficie á substancia das coizas, diffundindo entre elles hum libello diffamatorio, armado na supposição dos factos que nunca existirão...».

E a razão é que os livros libertinos mencionados na Pastoral já se achavam todos condenados pela Real Mesa Censória, e os dois de Du Pin e de Febrónio «tratão sómente de pontos de mera disciplina arbitraria e de pontos de jurisdicção que em nada interssão os Dogmas da Fé ou a Lei e Religião, como em artificioza e mal inventada impostura se quiz persuadir». Como fácil é de ver, não se consegue entender como seja possível fazer a ligação entre o que escreve o prelado de Coimbra e o raciocínio dos censores quando estes falam de ataques ao monarca e ao progresso que, dizem, se está a verificar no país.

Os autores franceses são considerados «materialistas e libertinos», "temerarios e prejudiciaes», ao passo que Du Pin é "respeitável e ortodoxo" e Febrónio "sábio», sendo todos compreendidos "debaixo de huma mesma qualificação vaga, violenta e contradictoria».

Estava-se numa época, continuam os censores, em que os jesuítas («despoticamente dominantes na Curia de Roma») procuravam por todos os meios levar as cortes europeias e os prelados diocesanos a defender as "reprovadas maximas da Bulla de Cea, dos Indices Expurgatorios e de todos os principios ultramontanos». E resultado disso é o facto de terem aparecido os Breves Apostolicum pascendi, Animarum saluti e outros, que têm dado o ensejo em Espanha e França ( «vasta e illuminada Monarquia") para serem publicados escritos do género da Pastoral de D. Miguel.

Não restam, pois, dúvidas que os jesuítas estiveram por detrás da Pastoral: «Ponderando a analogia, ou antes, identidade, que as mallicias da mesma Pastoral tem, com as mallicias praticadas neste Reino contra o Senhor Rey Dom Affonso, na forma assima ponderada; e considerando com reflexão tudo o referido, não podemos deixar de entender que a dita Pastoral, assim na substancia como no modo della, hé obra dos Jezuitas, e que constitui hum dos insultos mais atrozes 
que tem chegado à real preença de V. Mag.e, porque, não podendo nem devendo nós julgar dos interiores do Bispo, reservados a Deos, o que se prezenta por modo authentico na dita Pastoral, hé o corpo de hum delicto de rebelião notoria, e de outro delicto de sedição manifesta».

As provas estão à vista: «Por quanto, a Pastoral, em todo o seu contexto, respira o artificio e malicia jezuitica, pela forma com que está minutada; pelos pretextos falsos e affectados; pela fraze capcioza; pelo atrevimento inaudito e calumniozo de insultar e pôr de má fé na Religião os auctores e as pessoas de sãa e muito louvavel doutrina; e pela temeridade de querer asustentar as maximas ultramontanas, prejudiciaes ao socego publico, com as quaes se achão concentrados os mesmos Jezuitas, para os seus interesses, buscados por meios illicitos indecentes e dolozos, quaes são a calumnia, a desobediencia, o engano da gente simples e a sublevação dos Povos».

Dizer que a religião está em perigo é um excesso, uma falsidade, digamos, "porque nunca houve neste Reino, nem mais Religião na Corte, nem mais exemplar zelo e observancia della, não só nos Tribunaes e Magistrados, mas nem mais sizudeza e compostura de costumes na Nobreza e pessoas notaveis». E essa é a maneira de proceder jesuítica que com vagas calúnias semeiam a dúvida e a perplexidade, "temeridade de que se não mostrará exemplo algum, em outras ordens ou clas. ses de pessoas, porque é privativo estratagema dos mesmos Jezuitas».

0 bispo escolheu apenas alguns autores, o que significa que o seu fim não era a sua condenação que, aliás, já havia sido feita anteriormente. E,além disso, são fingidos "prejudiciaes no Bispado de Coimbra, sendo nelle, geral e inteiramente desconhecidos». O que significa que pretendeu misturá-los com Du Pin e com Febrónio, "que são os que mais pungem a Curia de Roma, porque nem os pode declarar por hereges, nem mostrar nelles propozição alguma que implique com os Dogmas». E uma mistura de autores libertinos e materialistas com os sábios e católicos Du Pin e Febrónio. Aqueles são merecedores de justa reprovação mas não estes . «Foi para injuriar a estes recomendaveis homens, e para injuriar a quantos adoptão as suas sans e importantes doutrinas, entregando-os desta forma á fatua decizão dos obstinados e ao escandalo dos simplices». Du Pin e Febrónio são, por conseguinte, defendidos da forma mais clara e inequívoca. A Pastoral foi, por conseguinte, forjada em Roma. A Roma interessava condenar os dois autores referidos e D. Miguel, levado pelo seu «temerario fanatismo» e sob a orientação dos jesuítas, não perdeu a ocasião de os condenar. 


\section{Miguel da Anunciação}

Até porque os nomes de Voltaire e Rousseau, etc. são desconhecidos em Coimbra; as pessoas não sabem se são «mineraes ou vegetaveis; se são viventes terrestres ou aquaticos, porque no Bispado de Coimbra não ouvirão nunca pronunciar taes nomes». Pelo que classificam a animosidade do bispo como um «insulto de rebellião e de sedição formal».

A seguir apresentam alguns dados que poderiam justificar a Pastoral: se ela tivesse sido publicada antes do dia 2 de Abril de 1768, data em que o rei proibiu a Bula da Ceia, os Indices Expurgatorios e os Indices em geral, chamando a si a censura de livros, em todos os seus aspectos. Se a Pastoral tivesse sido escrita antes de 5 de Abril daqule ano em que foi criada a Real Mesa Censória, que tinha "jurisdição privativa e excluziva, em tudo o que pertence ao exame, approvação e reprovação dos livros e papeis que já se achão introduzidos nestes Reinos e seus Domininos; dos livros e papéis que nelles entrarem de novo, ou seja pelos portos do mar, ou pelas raias seccas; dos livros e papeis que se pertenderem reimprimir, posto que antes fossem estampadas com licença; dos livros e papeis de nova compozição; de todas as Concluzoens que se houverem de defender publicamente, em qualquer lugar destes Reinos; e de tudo o mais que pertence á estampa, impressão, officinas, venda e commercio dos sobreditos livros, e papeis». Se a Pastoral tivesse aparecido antes da publicação da segunda parte da Deducção Chronologica e Analytica que determinou que não pode haver proibição externa de livros e papeis pela Igreja sem o consentimento e autoridade do rei, como sucede em «todas as Cortes Catholicas Romanas, mais pias e orthodoxas".

Se a dita Pastoral tivesse surgido antes da Deducção Chronologica e Analytica, "que illuminou todo o mundo", na qual se diz que os bispos não podem impedir a leitura de livros «que nos parecerem bons, havendo sido publicados com auctoridade do Soberano". O papa não pode «constituir-se juiz dos livros escritos sobre ambas as jurisdiçoens, espiritual e temporal». Os cidadãos têm o direito "de se instruirem nos direitos incontestaveis da sua Patria»; os eclesiásticos menos cultos não têm o direito de estar a proibir obras a seu capricho. Se a Pastoral tivesse vindo à luz antes da lei de 6 de Maio de 1765 , que proibia a divulgação de livros sem preceder o beneplático regio, ainda se aceitaria. Assim não há desculpa alguma, pois o bispo desrespeitou as «Leis sacrossantas e solemnes, a cuja observancia hé obrigado, como cidadão e como ecle. ziastico, desviando-se assim, dos exemplos de humildade que nos deixárão os Padres da Igreja primitiva, obedientissimos ás leis dos Soberanos, como meio necessario para a tranquili- 
dade dos Povos, da qual obediencia lhes tinha sido exemplar, Christo Senhor nosso, modelo de verdadeira piedade, á qual não se conformou a devoção inquieta e altiva deste mal consultado Prelado...». Concitou desse modo a animosidade das pessoas para criarem conflitos entre o sacerdócio e o império. A Pastoral é um "escrito de rebellião e sedição».

D. Miguel, dizem os censores, opôs-se às leis régias, negando ao monarca o poder que pelo direito natural e divino lhe compete; sem o poder de legislação não há soberania, acrescentam. Depois porque veio com a Pastoral perturbar o sossego e tranquilidade públicos, pelo que deve ser considerado "sediciozo e scismatico". As razões vêm desenvolvidas a seguir: alienou o sacerdócio do império, "confundindo e comprometendo os poderes de ambos, quando todo o objecto das illuminadas Leis de V. Mag. ${ }^{e}$, foi separar justamente hum do outro poder...» Não é costume os prelados publicarem pastorais manuscritas mas $D$. Miguel ,porque sabia que lhe seria negada autorização, avançou com o texto manuscrito, "para inquietar os vassalos, armar huns contra os outros e levantar o estandarte de divizão entre o Sacerdocio e o Imperio». Nem é costume virem os prelados condenar obras de quaisquer autores, recorrendo sempre aos reis para o fazerem. Agora que existe a Real Mesa Censória que uniu os três tribunais, o da Coroa, o da Inquisição e o Diocesano, veio o bispo de Coimbra intrometer-se num campo que lhe não competia, desprezando as leis régias e dando a entender que «esta Meza está inficionada com doutrinas perversas, quando hé notoria a vigilancia e actividade com que a Meza tem abolido os escritos daquelle abominavel caracter, qual hé o da irreligião, e com que trabalha por verificar quanto, pela sua repartição, pode concorrer para se conservarem illesos os Dogmas preciozos da nossa Fé $€$ o amor sincero e casto da nossa Santa Igreja Catholica Romana».

Esqueceu-se que o que preocupa os responsáveis pela impressão e divulgação dos livros é contribuir para o bem da religião em todos os domínios e para a promoção dos bons costumes. D. Miguel, procedendo como procedeu, agiu «inspirado pelo espírito de fanatismo, de desobediência e de rebelião".

As obras de Du Pin já há bastante tempo que corriam pelo país e nunca o prelado as condenara. $\mathrm{E}$ defendem rasgadamente aquele autor e também Febrónio, que "nos seus eruditissimos escriptos» atacam o abuso das excomunhões, a superioridade dos papas sobre o poder temporal dos reis e a doutrina dos que quiseram afirmar que o papa pode depor os soberanos e eximir os vassalos da obediência que lhes devem. O bispo de Coimbra vendo que as obras daqueles mes- 
tres não haviam sido proibidas pelo rei, rompeu o silêncio e veio condená-las, «retribuindo com esta infiel, pessima e turbulenta correspondencia, o amor, o zelo e a dilligentissima vigi-

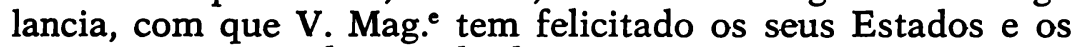
tem notoriamente levantado da tristissima situação em que os deixárão os Jesuitas, fazendo-os dignos do respeito das outras Naçoens».

Du Pin retratou-se de certos erros contidos em certas outras obras. Como "homem sabido e religiozo" teve a coragem de o fazer. Mas D. Miguel vai agora condenar uma obra "corrente, approvada e analoga com os sentimentos dignos da Igreja primitiva, quando os Homens Apostólicos ensinavão as maximas depuradas de projectos terrenos, e quando o fervor da mesma Igreja as sustentava para exemplo dos seculos futuros».

A referência na Pastoral à legítima licença para ler certos livros (não concedida, evidentemente) é objecto de uma crítica dura dos censores, como se os bispos pudessem sobrepor-se à Real Mesa Censória. 0 mesmo se diga da outra cláusula relativa à não absolvição de quem os ler. Tal coisa imputada é aos jesuítas de Roma que já noutras circunstâncias agiram desse modo a fim de corromperem as consciências. O mesmo sucedeu com a publicação da Bula Animarum Saluti (de 10 de Novembr ode 1766) que atinge a autoridade do rei e do Santo Ofício e dos prelados diocesanos. Tal Bula teria andado a ser divulgada de modo clandestino. Nela como na Pastoral se procurou envenenar os confessionários e usurpar as leis régias e as amplas jurisdições da Mesa Censória. $\mathbf{O} \mathrm{Pa}$ dre Manuel de Azevedo é referido como tendo estado por detrás de tudo isto.

A circulação da Pastoral daria origem a um «movimento perturbadissimo" e reduziria a harmonia política a um "tom irregular", pois contribuiria para o prejuízo das Letras e a ilustração das pessoas. Em vez da cultura que se deve promover a todo o transe, dar-se-ia cobertura às trevas da ignorância $\epsilon$ ao atraso intelectual do país sem falar já dos choques fatais que nasceriam entre os cidadãos. A Pastoral "prejudicial, imprudentisima e sediziosa» é, por conseguinte, condenada pelos censores da Real Mesa Censória. E em 23 de Dezembro de 1768 ordenou que fosse «lacerada e publicamente queimada com pregão na Praça do Comércio, pelo Executor da Jutiça». Efectivamente a pena cumpriu-se em 27 de Dezembro seguinte na presença do Dr. António Joaquim de Pina Manique.

Como escreve Joaquim Martins de Carvalho: «Esta Pastoral causou grande irritação no marquez de Pombal, porque parte dos livros que o bispo queria proibir eram d'aquelles 
que sustentavam o systema de governo adoptado pelo mesmo marquez». Era o caso de Du Pin e de Febrónio.

A 9 de Dezembro de 1768 foi dirigido ao cabido de Coimbra o seguinte decreto de el-rei para a eleição do vigário capitular: "Deão, dignidades, e cabido da sancta igreja cathedral de Coimbra. Eu el-rei vos envio muito saudar. Por quanto o bispo D. Miguel da Anunciação depois das minhas leis de 6 de Maio de 1765, 2 e 5 de abril do presente anno, levantando-se manifesta e publicamente contra ellas, espalhou na sua diocese e nesta corte, debaixo de simulados titulos, differentes papeis sediciosos e offensivos dos mais saudaveis direitos da minha coroa e do socego publico, fazendo-os clandestinamente passar ás mãos dos parochos para elaquearem as consciencias dos seus respectivos freguezes; não só sem conhecimento algum meu, e sem preceder o meu consenso e real beneplacito, que era o que bastava; mas tambem inventando muito pelo contrario para d'elle fugir, a desudada ideia de espalhar ultimamente manuscripta a intitulada pastoral de 8 de novembro proximo passado, e contra o geral costume d'aquelle e dos mais prelados do reino, segundo o qual não podia correr a dicta pastoral, senão havendo sido estampada, com previa approvação minha, para mim se evitarem absurdos ainda meno res, que os inauditos com que deslisou o referido bispo, pela composição e adopção, uso e dispersão da sobredicta pastoral, pelos abominaveis e notorios crimes de lesa magestade, que nelle e na sua clandestina dispersão accumulou; incorreu desde a commissão dos sobredictos factos na disposição das referidas leis, e entre ellas a especial na de 2 de abril, que estabeleceu contra os transgressores d'ella (qual foi o mesmo bispo), as penas da minha real e grave indignação, da confiscação de todos os seus bens para a minha camara, da privação da naturalidade d'estes meus reinos e dominios, para mais não gozar das honras e utilidades de que gozam os vassallos delles, e das mais penas estabelecidas contra os que conspiram, ou para as offensas da minha regia magestade, ou para as ruinas dos meus reinos, ou para a perturbação do publico socego; executando-se irremissivelmente as sobredictas pennas contra os transgressores, em todos e cada um dos casos determinados; sem que seja preciso que todos elles concorram copulativamente: por quanto pela natureza dos referidos crimes de lesa magestade, como taes exclusivos de todo o privilegio e foro, que não seja o de meu regio e immediato conhecimento, pelo ministerio da mesma lei, e pela notoriedade dos mesmos crimes, ficou o referido bispo incurso nas penas sobredictas, desde a hora em que as commetteu, sem necessidade de esperar para isso sentença: por quanto desde que o mesmo bispo 


\section{D: Miguel da Anunciação}

cahiu debaixo das dictas penas, foi reputado por morto, e o governo vago d'esse bispado.

«Em consideração de todo o referido, como protector que sou dos meus reinos e dominios, e do concilio de Trento, me pareceu significar-vos que na forma do mesmo concilio deveis constituir vigario capitular que governe o bispado, com cessão de toda a jurisdicção, sem reserva, em quanto não houver legitimo pastor diocesano. E porque tenho informação das letras e virtudes de Francisco de Lemos de Faria, desembargador da casa da supplicação, juiz geral das ordens e deputado do sancto officio, me será muito agradável que façaes eleição da sua pessoa para o referido emprego, por confiar d'elle cumprirá como deve a sua obrigação. Palacio de Nossa Senhora da Ajuda, 9 de Dezembro de 1768. — Rei.»

\section{APENDICE DOCUMENTAL}

I - D. MIGUEL DA ANUNCIAÇÃO PORCIONISTA DO COLEGIO DE S. PAULO

Dom João por Graça de Deos, Rey de Portugal e dos Algarves daquem e dallem, em Africa Senhor de Guine etc. Como Protector que sou da Universidade de Coimbra, e do Collegio Real de S. Paulo della, faço saber a Vos Reytor, e Collegiaes do mesmo Collegio, que tendo respeito ao que me reprezentou o Conde de Pavolide em razão de que elle determina mandar seu filho segundo Miguel Carlos da Cunha estudar a dita Universidade, e que recolhendose por Porsionista no dito Collegio podera mais comodamente seguir, e aproveitar os Estudos me pedia lhe fizese mersse de hum lugar de Porsionista no dito Collegio para o dito seu filho, e tendo respeito ao que allega e o que precedendo informação e parecer se me consultou pello meu Tribunal da Meza da Consciencia e Ordens; Hey por bem fazerlhe merce para o dito seu filho do Lugar de Porsionista que de prezente se acha vago no mesmo Collegio, e que esta Provizão se cumpra e guarde, posto que seu effeito dure mais de hum anno, sem embargo da ordenação em contrario. El Rey nosso Senhor o mandou pello Arcipreste da Santa Igreja da Santa Igreja Patriarcal e Dom Lazaro Conego da mesma Patriarcal ambos de seu Conselho e Deputados do despacho do Tribunal da Meza da Consciencia e Ordens. Victorino Joze Pereira de Souza a fez em Lixboa 28 de Septembro de 1719.

Manoel Coelho Velho a fez escrever.

Arcipreste da Santa Igreja Patriarcal D. Lazaro Conego da Santa Igreja Patriarcal

Cumprase e Registese Collegio Real em Capela de 13 de Outubro de 1719

Rebello Reitor

Per resolução de Sua Magestade de 25 de Septembro de 1719; em consulta da Meza da Consciencia e Ordens de 20 do dito mez, e anno.

A.U.C., Provizoens, t. VII, fl. 132 


\section{O Marquês de Pombal}

\section{II - MATRICULA EM INSTITUTA}

Miguel Carlos da Cunha $f^{\circ}$ dos condes de Povolide com certidão de Theologia da Congregação do Oratorio o p.* de 8 . bro.

Matriculas, vol. $39,1 .^{\circ} 1$, fl. 269 v. ${ }^{\circ}$

\section{III - EXAME DO B.EL MIGUEL CARLOS DA CUNHA N.AL DE LX."}

Aos 18 de Mayo de $1724 \mathrm{Na}$ sala da Vnid.e em presenca do Ill.mo S.or R.or sendo Padr.o (em branco) se juntaram todos os docentes canonistas em presença de todos se leo a sua lição de Ponto q. lhe foi asignada Miguel Carlos da Cunha e lida ella lhe argumentaram os DD seus MM e acabados os argomentos, votaram por AA. e RR. e regulados os votos sahio por todos aprovado Nemine Discrepante e logo fes o juram.to da Conceição e recebeo o grao do Padr.o q. lhe deu Authoridate app.ca de q. foram tt.as os D. M.el Nobre Pr.a e M.el Bras Anjo de que fis este termo. Fran.co Marq.es de Andr.a o escrevi.

R.or Dr. Tavares P. Juis

Autos e Graus, vol. 59, fl. 37.

\section{IV - FORMATURA DE MIGUEL CARLOS DA CUNHA PORCIONISTA DE S. PAULO}

Aos 16 de Mayo de $1725 \mathrm{Na}$ sala da Vn.de estando presente o Ill.mo S.or R.or sendo Padr.o o Dr. João de Moura de Goueja se juntaram todos os LentesCanonistas em presença de todos fes a sua lição de ponto q. Ihe foi asignada Miguel Carlos da Cunha e finda ella lhe argumentaram os DD. seus M.M e acabados os argomentos sahio o defendente p.a fora e fechadas as portas votaram por pontos sobre a penitência e por AA e RR. sobre a aprouação e registados os uotos foi por todos aprouado Nemine Discrepante e não foi penitenciado de q. fis este termo Franc.co Marques de Andr.a o escreui

R.or

Autos e Graus, vol. 60 , fl. 59 v. ${ }^{\circ}$

Moura P

\section{V-SUFFICIENCIA DE MIGUEL CARLOS PORCIONISTA DE S. PAULO}

Aos 28 de Mayo de $1725 \mathrm{Na}$ Sala da Vn.de estando prezente o Ill.mo S.or R.or sendo Padr.o o Dr. Ant. ${ }^{\circ}$ de Andr.a Rego se juntaram todos os lentes canonistas e em presença de todos leo Miguel Carlos da Cunha a lição de ponto q. lhe foi designada e finda ella lhe argomentaram os DD. seus MM e acabados os argomentos se fes tudo mais q. dispoem os estatutos de q. fis este termo Fran.co Marques de Andr.a o escrui

Autos e Graus, vol. 60, fl. 73 


\section{Miguel da Anunciação}

\section{VI - GRAO DE LDO. DE MIGUEL CARLOS DA CUNHA PORCIONISTA DE S. PAULO}

Aos 21 de Junho no mesmo dia atras escrito na Capella Real da Vn.de em presença do Rm.o D. João de S. Mamede sendo Padr.o o D.or M.el Borges se juntaram todos os lentes canonistas em prezença de todos fes Miguel Carlos da Cunha as conclux digo o juram.to da Conseição e recebeo o grao de L.do de Rm.o D. João de S. Mamede q. lhe deu auctoritate app.ca e lhe consedeo licenca p.a tomar o capello todas as vezes q. quizer de q. foram tt.as os DD. Fran.co de Alm.da Cayado e An.to de Andr.a Rego de q. fis este termo Fran.co Marques de Andr.a o escreui

Autos e Graus, vol. 60, fl. 84 v. ${ }^{\circ}$

\section{VII - EXAME PRIVADO DE MIGUEL CARLOS DA CUNHA PORCIONISTA DE S. PAULO}

Aos 21 de Junho de 1725 na Capella Real da Vn.de estando prezente o Rm.o João de S. Mamede vicecanselario da Vn.de sendo Padr.o o P.e M.e D.r Fr. João do Valle se juntaram todos os lentes M.M. e D.D. da d.a faculdade e o conserv. digo sendo Padr.o o Dr. M.el Borges de Serqr.a se juntaram todos os lentes canonistas e juristas, o conseruador Bedeis e meirinho e guarda e dita a missa uieram todos acompanhando p.a a caza dos exames priuados a Miguel Carlos da Cunha e fechadas as portas leo a sua pr.a lição de ponto qu elhe foi asignada e finda ella sahio p.a fora a recapacitar a memoria p.a a seg.da lição tocando o sino o sinal uejo p.a dentro e fechada as portas leo a seg.a lição q. lhe foi asignada e finda ella lhe argumentaram os D.D. seus M.M. Fran.co de Almada Cayado Joseph Pedro da Camara Giraldo Pr.a Coutt.o e Diogo Cardoso de Alm.da e acabados os argomentos sahio o defendente p.a fora e fechadas as portas hi de bacho do juram.to e que recomendam os estatutos e o Rm.o Vicecanselario recomendou o mesmo da parte de S. Mag.de e o Padr.o Requereo a ustiça do defendente e logo se uotou por pontos sobre a penitencia e por AA. e RR. sobre a aprouação e regulados os uotos não foi penitenciado e foi por todos aprouado Nemine discrepante de q. fis este termo Fran.co Marques de Andr.a o escreui

\section{João de S. Mamede Fran.co Carn.ro de Figueiroa}

Vice cancellario

Autos e Graus, vol. 60, fl. 84

\section{VIII - DOUTORAM.TO DE MIGUEL CARLOS DA CUNHA PORCIONISTA DE S. PAULO}

Aos 2 de Julho de 1725 no terreiro de S.ta Cruz sendo Padr.o o Dr. Joseph Pedro da Camara se juntaram todos os lentes e D.D. das quatro faculdades e os M.M. em Artes e Bedeis meirinho e Conseruador e as charamellas e todos a cauallo com suas insignias e por sua ordem acompanharam o Doctorando Miguel Carlos da Cunha athe a Capella Real da d.a Vn.de e ouuida a missa do grao foram todos acompanhando o Doctorando p.a a Sala da Vn.de e asentados todos por sua ordem propos o Ill.mo R.or João de S. Mamede vigario do Real Con- 


\section{O Marquês de Pombal}

vento de S.ta Cruz vicecanselario da Vn.de e logo propos a questam simbolica $\mathrm{c}$ lhe respondeo o Doctrando e finda fes logo o Dr. Fernando Joseph de Castro a pr.a oração e a seg.da o Dr. Thomas Ayres de Castro e findas ellas fes o Doctorando a portestação da fee com juram.to da conseição e recebeu o Grao q. lho deu o Rm.o P.e uice Cancelario D. João de S. Mamede auctoritate app.ca e logo cometeo as suas vezes ao Padr.o p.a o condecorar com as insignias Doctorais o q. logo fes com huma oração laudatoria e finda se fes tudo mais que dispoem os estatutos de q. fis este termo Fran.co Marques de Andr.a o escrui

Autos e Graus, vol. 60, fl. 88 v. $^{\circ}$

\section{SOBRE OS JACOBEUS QUE DEVIAM SER EXCLUfDOS DA UNIVERSIDADE}

\section{(14 de Dezembro de 1768)}

JOSEPH ANTONIO DE SOUZA PEREIRA, Vice Reitor, Lentes, e Deputados, e Claustro da Universidade de Coimbra. EU ELREY vos invio muito saudar. He notorio a todo este Reino, que de certos annos a esta parte contaminou o espirito de soberba, de ambição, e de cubiça, algumas das Ordens Regulares: $\mathbf{E}$ que os Individuos dellas, que se precipitàram naquelles abominaveis vicios, procuràram cubrillos com os exteriores pretextos da periendida mayor perfeição Religioza, debaixo dos quaes de apartáram do commum das suas respectivas Profissóes, e por necessaria consequencia das Regras das Santas Constituições, cuja religioza observancia collocou tantos, e tão grandes Santos sobre os Altares da Igreja de Deos: Denominando-se livre, e arbitrariamente os que assim se apartàram do modo de viver das Communidades das suas respectivas filiaçoes com as antonomazias de Jacobeos, Beatos, e Reformados: Inventando novos modos de vestir, e calçar; novas Tonsuras; novas, e exquizitas rezas, e Orações não approvadas pela Igreja, como se pudessem ser mais pios, do que a mesma Igreja, ou esta necessitasse daquelles particulares, e estranhos accrescentamentos de piedade: Levantando com os fingimentos della nas suas respectivas Ordens huma sedição sismatica, não só contraria á páz, que Christo Senhor Nosso veyo trazer ao Mundo, mas tão bem posta á fraternal, e caritativa união, que necessariamente deve haver entre os Religiosos Filhos dos seus táo bem respectivos Patriarcas: $\mathrm{E}$ havendose obstinado os Chefes, e Sequazes das mesmas sismaticas sedições com huma tão incorrigivel contumacia nos attentados, com que as tem proseguido até o dia de hoje, que com desprezo dos muitos, e muito saudaveis remedios, que repetidas vezes tenho applicado para que cessasse hum tão perniciozo mal, se tem engravecido cada dia mais deploravelmente, e em tal forma, que os estragos delle, depois de haverem por muitos annos arruinado os Patrimonios, a Disciplina Regular, e a reputação das sobreditas Ordens contaminadas, passàram á extremoza audacia de attacarem tão bem o socego publico dos Meos Reinos, tanto quanto se acaba agora de manifestar nessa Cidade, e na de Braga por modos tão claros, e decisivos, como escandalozos. E porque nestas urgentes circunstancias tomei na Minha Real, e seria consideração tudo o referido depois de ter visto por tantas experiencias o claro, e decisivo dezengano, de que todos os meyos de mayor suavidade, e brandura, de que até agora uzei, serviram só para fazerem grassar cada dia mais 


\section{Miguel da Anunciação}

huma tão pestelenta, e contagioza enfermidade da Religião, e do Estado: Ponderando sobretudo o referido como Padroeiro, e Protector que SOU dessa Universidade, o desdouro, e nota, que se lhe seguiria de conservar ia sua Corporação aquelles Regulares, que fizeram tão reprehensiveis abuzos dos graos de Doutores, e das Graduações de Mestres Theologos que nella conseguiram: Principalmente os da Ordem dos Conegos Regrantes de Santo Agostinho, que tenho mandado excluir das Prelaturas, e Officios da dita Congregação, como declarados, e manifestos simuladores, e propugnadores da Reforma, que nunca houve na realidade; os da Ordem dos Eremitas Calçados de Santo Agostinho, que atè agora fizeram profissão das sobre ditas singularidades de Nomes, e de Habitos; os da Congregação de São Bento, que com igual notoriedade se acham no mesmo cazo; sendo os das referidas Tres Ordens os que tem dado mais publico escandalo: Mando que todos, e cada hum dos sobreditos sejam logo riscados dos Livros da mesma Universidade, com inhabilidade tal que nella, e nas suas Aulas não possam mais ser admittidos, nem ainda por meros assistentes; pois que a todos os respeitos devem ficar reputados por mortos, como se nunca houvessem existido. $O$ que tudo fareis executar: Registandose esta nos Livros das Minhas Reaes Ordens: $\mathbf{E}$ inviandose pela Secretaria de Estado dos Negocios do Reino Certidão, de se haver assim cumprido. ESCRIPTA no Palacio de Nossa Senhora da Ajuda a quatorze de Dezembro de mil setecentos sessenta e oito.

\section{Rey}

Para Joseph Antonio de Souza

Pereira, Vice Reitor, Lentes, Deputados, e Claustro da Universidade de Coimbra.

\section{POR ELREY}

A Joseph Antonio de Souza Pereira Vice Reitor, Lentes, Deputados, e Claustro da Universidade de Coimbra.

A. U. C., Documentos Avulsos

IX - SOBRE O SEMINARIO EPISCOPAL DE COIMBRA

Governo do Ex. ${ }^{\text {mo }}$ Sr. Bispo Conde D. Miguel da Anunciação desde Junho de 1741 - Agosto de 1779

\section{Memória}

Sobre o Seminario Episcopal de Coimbra dividida em cinco Epochas, Comprehendendo

1. O governo do Ex. ${ }^{\mathrm{mo}} \mathrm{Sr}$. Bispo Conde D. Miguel da Anunciação fundador do Seminario desta cidade anno - 1741 - a 1779 


\section{O Marquês de Pombal}

2. $O$ governo do seu sucessor o Ex. ${ }^{\mathrm{mo}} \mathrm{Sr}$. Bispo Conde D. Francisco de Lemos desde $1780=$ até Anno de 1822 - e dos seus successores os Ex. ${ }^{\text {mos }}$ S.es D. Fr. Francisco de S. Luis e D. Fr. Joaquim da S. ${ }^{\text {ra }}$ da Nazareth: desde $1822=1834$.

3. ${ }^{a}$ Desde $1834=1842$; Morte Civil do Seminario. Governo dos Vigarios Capitulares.

4. ${ }^{\text {D }}$ Desde o fim de Septembro de 1842 até o fim de Abril de 1852, comprehendendo o governo do Vigario Geral - o $\mathrm{D}^{\mathrm{r}}$ Antonio Jose Lopes de Moraes, nomeado por Sua Santidade a instancias e sobre proposta de Sua Magestade Fidelissima a Rainha Senhora D. Maria Segunda.

5. Desde o fim de Maio de 1852 = até o anno corrente -1879 , comprehendendo o governo dos Ex. ${ }^{\text {mos }}$ S. ${ }^{\text {res }}$ Bispos Condes - D. Manuel Bento Rodrigues, D. José Manuel de Lemos, e do actual - D. Manuel Correa de Bastos Pina.

\section{1.a Epocha}

A do Ex.mo Sr. Bispo Conde - D. Miguel da Anunciação, sua naturalidade e filiação, sua vida Academica, sua profissão na Ordem dos Conegos Regrantes no Mosteiro de Santa Cruz em Coimbra, sua ordenação, sua elevação ao Episcopado da Diocese de Coimbra; posse do Bispado; sua Sagração, sua entrada publica e solenne na Cidade de Coimbra, dirigindo-se a Sé. Fundação do Seminario; Estatutos que ordenou para elle; Erecção da Congregação dos pios Operarios; sua prisão em 9 de Dezembro de 1768; sua soltura em 23 de Fevereiro de 1777; seu regresso para Coimbra; sua morte no fim de Agosto de 1779 nas hospedarias do Convento de Semide; Conducção do seu Corpo para a Igreja do Mosteiro de Santa Cruz em Coimbra, onde jaz sepultado.

O autor desta Memoria começou a ser na idade de 9 annos alunno do Seminario Episcopal de Coimbra, onde viveu por muitos annos; offerecendo-se-lhe neste espaço de tempo muitas occasióes para lêr papeis existentes no mesmo Seminario, nos ques estavão esciptas noticias de causas que lhe disião respeito taes como a sua fundação, o seu regimen e quaes os Padres empregados na educação dos alunnos, Ordinandos e Porcionistas e na sua instruç̧ão em humanidades e Sciencias Ecclesiasticas, foi colligindo quantas noticas encontrou a este respeito e lembrando-se de que ellas chegando a ser publicadas poderão agradar a curiosidade de todos, principalmente da dos Ecclesiasticos e de que com este serviço daria um testemunho de gratidão ao mesmo Seminario, ainda que pequena paga para tamanha dívida, resolveu-se a pô-las por ordem de maneira que pudessem merecer o nome de $\mathrm{Me}-$ moria sobre a fundação e regimen do Seminario Episcopal de Coimbra - Estabelecimento o qual começado em 1748 conta já 130 annos de existencia.

Destinado para um fim tão santo, e tão proveitoso, qual não só a educação e a instrução do Clero, que sendo a luz do Mundo e o sal da terra, morigerando os povos deve dirigil-os por caminhos rectos para o Céu, se não também a instrucção secundaria do Nobre, e estudiosa Mocidade, a qual togada vai prestar à Patria mui relevantes serviços nos altos empregos de Magistratura administrando com rectidão 


\section{Miguel da Anunciação}

justiça aos povos reprimindo e castigando o crime, que campêa desagrado, e protegendo os desvalidos orfaos e viúvas, parece que tão santa Obra foi abençoada pelo Omnipotente lá dos altos Céus como viveiro abundantíssimo de mimosas plantas, para que não só se conservasse, mas continuasse a existir crescendo de dia para dia cada vêz mais.

E na verdade a numerosa afluencia dos humanos que se acolhem a esta Santa Caza para receberem educação, e instrucção, tem crescido tão prodigiosamente, que os quartos existentes não chegão já para tanta gente: mesmo até o anno de 1832 houve alguns annos, em que se apresentou tão grande numero de ordinandos, que não chegando os quartos para elles destinados, foi necessario recolhêl-os em cazas no interior do mesmo seminario.

A vista deste acontecimento era bem manifesta a urgencia de acrescentar o antigo Edifício do Seminario; não consta porem que á memoria dos Prelados de então accorresse esta empreza; lembrança e gloria tal estava reservada para o actual Ex. ${ }^{\text {mo }}$ S.r ${ }^{r}$ Bispo Conde o zeloso e incansavel S.r D. Manuel Corrêa de Pina Bastos, nosso dignissimo Prelado, o qual fez já um grande accrescentamento no terreno contíguo no antigo Edifício, e talvez que este mesmo careçe de augmento.

Na longa serie dos illustres Prelados( que tem governado a Diocese de Coimbra, brilhão como astros mui resplandecentes dois egregios varões, D. Miguel da Anunciação e D. Francisco de Lemos, aquelle não só pela fundação do Seminario, que começou e acabou, se não pelas gravissimas tribulações, que o atormentárão durante o seu governo, soffrendo uma duríssima prisão em Lisboa por espaço de 8 annos, e alguns meses, desde Dezembro de 1768 até Fevereiro de 1777 motivada pelo excesso do seu zelo pastoral; este pelos relevantes serviços, que prestou à Pátria na republica literaria na reforma da Universidade durante o ministerio do Marquez de Pombal, e na politica por ser um dos 12 illustres varões escolhidos para governarem a Deputação Portuguesa, que em 1808 foi à França cumprimentar o Imperador Napoleão $1 .^{\circ}$, o qual o considerou como personage de merecimento digno d'attenção.

Portanto não é possível escrever uma Memória sobre o Seminário sem tocar nos pontos mais culminantes da vida destes dous insignes Prelados da Igreja Lusitana em geral, e da Conimbricense em particular. Começarei por mesmo porque assim o pede a ordem chronologia pelo Fundadôr do Seminário o Ex. ${ }^{\text {mo }}$ S. ${ }^{r}$ D. Miguel da Anunciação.

Tendo eu comunicado ao Ex. ${ }^{\text {mo }}$ S. $^{\mathbf{r}}$ Bispo Conde a tenção, que tinha de compôr esta Memoria, S. Ex. acolheu esta noticia com tanta affabilidade, e satisfação, que as benevolas expressões, com que se dignou honrar-me, derão-me animo bastante para logo pôr mãos à obra, não poupando trabalho, nem diligencia, tanto quanto as minhas debeis forças o permitião. Possão estas minhas lucubrações agradar a Sua Ex.a, ao R.do Clero e ao respeitavel publico.

Se por ventura porem não agradarem, sirvão ao menos d'estimulo para que outrem dotado d'engenho, e arte, que eu não possuo, apresente no futuro Obra perfeita sobre este mesmo assumpto -

\section{Anunciação. \\ Naturalidade, filiação e educação do Ex. ${ }^{m o} S r$. D. Miguel da}

Nasceu em Lisboa a 18 de Fevereiro de 1703; seu Pae foi Tristão da Cunha de Ataide, Senhor da Villa de Pombeiro, a quem El Rei D. João $5 .^{\circ}$ por seu decreto de 25 de Agosto de 1749 elevou a Conde da mesma Villa e nomeou Presidente da Junta do Tabaco; sua Mãe foi a Condessa D. Archangela Maria de Tavora. 
Veio para Coimbra e foi Porcionista do Collegio de S. Paulo Apostolo, usando o nome de Miguel Carlos da Cunha, frequentou na Universidade a Faculdade de Canones na qual tomou o grau de Doutor em 2 de Julho de 1721 e foi Lente da mesma. Toma o habito de Frade no Mosteiro de S.ta Cruz em Coimbra, e professa tomando o nome de D. Miguel da Anunciação.

Tendo vindo para Coimbra a reforma no Convento de San(ta) Cruz, Fr. Gaspar da Encarnação, Frade Varatojano, grande valido d'El Rei D. João $5^{\circ}$, trazendo em sua companhia outros Frades da mesma Ordem, e 3 filhos bastardos do mesmo Rei, a saber D. Gaspar, D. José e D .António, denominados os Meninos de Palhavã, por habitarem na Cidade de Lisboa num Palacio assim denominado, o Sr. Miguel Carlos da Cunha attrahido pelo dicto Reformador resolveuse a tomar o habito de Frade Cruzio, e com affecto o tomou a 26 de Abril de 1728 tomando então o nome de D. Miguel da Annunciação.

Toma Ordens desde as menores ate á de Presbytero. Foi logo Ordenado de menores, e d'Epistola a 22 de Maio de 1729, d'Evangelho a 26 do mesmo mes, e de Missa a 26 de Junho do mesmo anno e tudo na Capella de S. Theotonio; e foi Ordenado pelo Bispo d'Angola, D. Luiz Simões Brandão, o qual era natural de Coimbra filho de Jose S1mões (Carpinteiro) e tinha tomado o grau de Doutor na Faculdade de Theologia na Universidade.

Tendo D. Miguel da Annunciação 9 annos d'habito, e 34 de idade foi nomeado Geral da Congregação a 6 de Abril de 1737 pelo dicto Reformador Frei Gaspar sendo o primeiro Geral depois da Reforma.

\section{Miguel da Annunciação é elevado à Dignidade de Bispo Con- de da Diocese de Coimbra.}

Havia 22 annos que tinha vagado a Mitra de Coimbra por falecimento do Sr. Bispo Conde D. António de Vasconcellos em 1717. Este Senhor B. ${ }^{\circ}$ era natural da cidade d'Elvas onde nascera a 28 de Agosto de 1645 sendo seu Pai o 2..$^{\circ}$ Marquez de Castello Melhor. Foi primeiro nomeado Bispo de Lamego, Emprego do qual tomou posse em 9 de Fevereiro de 1693; d'aqui foi transferido para o Bispado de Coimbra, do qual tomou posse por seu Procurador D. José de Almada em 6 de Abril de 1706, e governou o Bispado até o anno de 1717, em que falleceu, como já está dicto. Desde então foi o Bispado governado por Vigarios Capitulares, sendo o primeiro Jose Freire de Faria, natural do Espinhal e o segundo o Bispo de Angola D. Luís Simões Brandão, que acima nomeamos.

O Sr. D. Miguel da Annunciação no seu 2. anno de Geral foi nomeado Bispo de Coimbra a 11 de Fevereiro de 1739 , sendo proposto em Roma no Consistorio de 9 de Dezembro de 1740; para esta nomeação concorreu muito o dicto Reformador Fr. Gaspar da Encarnação.

O Sr. D. Miguel da Annunciação manda apresentar as suas Bullas de Confirmação ao R. ${ }^{\text {mo }}$ Cabido, e manda tomar posse do Bispado.

No $1 .^{\circ}$ de Fevereiro de 1741 mandou o Sr. D. Miguel da Annnunciação apresentar as suas Bullas de Confirmação no Bispado de Coimbra ao R. ${ }^{m}$ o Cabido da Sé para que este examinasse se ellas estavão em termos de lhe dar posse e sendo ellas approvadas pelo R. ${ }^{\text {mo }}$ Cabido nemine discrepante, passou então S. Ex. ${ }^{a}$ procuração ao R. ${ }^{\text {mo }}$ Deão da mesma Sé Mons. D. José Peixoto d'Azevedo Machado, o qual com effeito tomou posse em nome de S. Ex. no dia 2 do dicto mez às 2 horas da tarde. 


\section{Miguel da Anunciação}

Sua Sagração no dia 9 d'Abril do mesmo anno. A isto seguiuse a sua Sagração na mesma Igreja de Santa Cruz na Dominga in Albis 9 de Abril do dicto anno. S. Ex. ${ }^{a}$ no dia 8 (vespera) tinha dado parte ao R. ${ }^{\text {mo }}$ Cabido de que no seguinte havia de verificar-se aquella funç̧ão e pedialhe, que o encommendassem a Deus para que recebesse os podêres de Bispo na sua divina graça. O R.do Cabido votando nesta materia resolveu, que no Sabbado de tarde depois de completa se expusesse (aberto o Sacrario) o SS. ${ }^{m_{0}}$ Sacramento, e se fizes-sem pêla Communidade preces pela intenção do dicto Sr. Bispo Conde, e que no Domingo se repicassem os sinos ao mesmo tempo que se tocassem em Santa Cruz, e que á noite se pusessem na Sé luminarias, e em suas cazas os R.dos Capitulares, mas que isto se fizesse por obsequio, e não por obrigação, e que tambem por mero obsequio, e não por obrigação fossem assistir á dicta Sagração seis Revrendos Capitulares adornados de sua murça, e sobrepellises, os quaes logo se nomeávam, porque já de parte do R.do Cabido havia o S. ${ }^{\circ}$ Deão practicado com o R. ${ }^{\mathrm{m}} \mathrm{o} \mathrm{Sr}$. Reformador dar-se-lhes logar condigno adiante pegado ao P.e Geral ficando immediatos a elle. A Sagração verificou-se no dia 9 de Abril na Igreja de Santa Cruz sendo Sagrante o Bispo d'Angola D. Fr. Valerio do Sacramento, e assistentes o Bispo de Macau D. Fr. Hilario de S.ta Rosa, e o do Funchal D. Fr. Jose do Nascimento

Sua entrada publica, e solene segundo o Ceremonial na Cidade, e na Sé

Em 11 de Junho do sobredicto anno 1741 fez o Ex. ${ }^{\text {mo }}$ Sr. Bispo Conde a sua entrada publica e solenne segundo o Ceremonial na Cidade, e Sé de Coimbra.

Para este fim o R.do Cabido saiu da Sé acompanhado de todo o Clero, das Confarias, e Irmandades, e do Seminario, por ordem, que para isso passou o D.or Provisor, indo tambem os Frades de S. Francisco da ponte, e do Convento de S. Domingos, como são obrigados todas as vezes que o K.do Cabido sae da Sé em forma de Procissão; encaminhou-se pelas Ruas de S. Christovão, das Fangas, da Cálçada, de Coruche, e de S.ta Sophia até ás portas de Santa Margarida.

Aqui tinha sido armado um taburno de 4 degraus de altura, immediato ás portas, e da parte do monte no meio do Taburno o Solio Episcopal, e aos seus lados os assentos para o R.do Cabido.

O Sr. Bispo foi para a Capella da Senhora do Lorêto aqui vestiuse com os habitos Episcopaes, e montou a cavallo numa mula prêta com gualdrapa e arreios cobertos de pano rôxo, e dahi abalou acompanhado por 4 Conegos montados tambem em mulas com gualdrapas prêtas, e elles com vestidos talares de muella negra e atrás do Sr. Bispo vinha montado a cavallo João de Sá rogado para seu Candatario e o Estribeiro de S. Ex. ${ }^{a}$ diante dos 4 Conegos vinhão os Capellães, e Pagens do Sr. Bispo Conde, e adiante d'estes os Ministros da Cidade, os Fidalgos d'ella e alguns Nobres. As 4 horas da tarde chegou o Sr. Bispo Conde aonde o R. ${ }^{\text {mo }}$ Cabido estava esperando, ás portas de S.ta Margarida; aqui apeou-se e ajoelhou em uma almofada posta sobre uma alcatifa extendida na rua junto ao Taburno, e ahi o R.do Deão vestido de capa d'Asperges branca lhe deu a beijar a Cruz; feito isto levantou-se e subiu para o seu solio, pegando-lhe na cauda João de Sá. Vierão logo dous Conegos a servirem de Diaconos assistentes, 


\section{O Marquês de Pombal}

que o vestirão Pontificalmente, e o R.do Deão lhe metteu o annel no dêdo.

Então foi-se expedindo a Procissão e saindo da Rua de Santa Margarida dous a dous forão passando por diante do Sr. Bispo Conde pondo um joelho em terra e seguia-se em último logar o Clero da Freguesia da Sé, Capellães e Musicos d'ella cantando hymnos, e logo se seguia o R.do Cabido fazendo inclinação profunda ao Sr. Bispo passando por elle dous a dous.

Desceu o Ex.mo Prelado do seu solio, e montando em um cavallo ruço com gualdrapa, e arreios cobertos de setim branco abalou para as portas da Cidade, onde o Vereador mais velho lho representou da parte do Senado, e da Cidade, a alta estimação, com que esta se gratulava de receber um Prelado, que adornado de tantas excellencias, e virtudes lhe promettia umas firmes esperanças de se ver Coimbra, e o seu Bispado, no seu governo cheia de felicidades, e logo o receberão os Camanistas debaixo do Pallio, e chegou assim ao Terreiro de Samsão, onde havião feito paragem 8 cavalleiros Fidalgos, se entregaram estes das dictas Varas defronte das portas da Igreja do Mosteiro de Santa Cruz: d'ahi caminhando pelas ruas do Coruche, Calçada, arco de Almedina, rua das Fangas, S. Christovão, o conduziram e acompanharani até ás portas da Sé. onde da parte de dentro estava estendida uma alcatifa, sobre que parou o Sr. Bispo Conde, e o R.do Deão lhe deu agua benta, e incenso para o dicto Senhor fazer o thuribulo, com o qual elle Deão o incensnu $\mathrm{rnm} 3$ ductos tendo tomado para isso a Capa d'Asperges na entrada da Sé; d'ahi se encaminhou á Capella do Santissimo, onde estava um genuflexorio de pano verde, e se assentou no seu solio, e aos seus lados os dous Conegos assistentes, e veio o R.do Cabido de dous em dous tomar-lhe a benção, estando em todo este tempo cantando a Musica o Te Deum - ministrando-lhe o Baculo o R.do Arcediago da Cidade; o R.do Deão disse os versos costumados em tal acto, e a Oração de Nossa Senhora da Assumpção Orago da Sé e publicou finalmente as Indulgencias.

Então saiu o Sr. Bispo para o seu Paço acompanhado do R.do Cabido, Clero, e Nobreza; e no seu Paço acampanhou o R.do Cabido até ás portas da escada d'elle. Nesse dia, e nos dous seguintes houve na Sé, e por toda a Cidade, repiques e luminarias.

$\mathrm{Na}$ segunda feira pelas 9 horas da manhã mandou o Cabido 2 Capellães a Cortejar o dicto Sr. Bispo Conde, e depois d'elles recolhidos se lhe mandou o presente costumado de duas duzias de caixas de doce de dez arrobas cada uma acompanhadas as mulheres, que as conduzirão, d'um Capellão da Sé, que levava uma Carta do R. mo Cabido, cheia d'expressões, d'affectos, e de supplica para a indulgencia d'aquella Communidade fundada na honra, que o Cabido deve sempre aos Senhores Bispos Condes; e á dicta Carta respondeu o dicto Senhor com as attenções, que na excellencia da sua dignidade, e de sua Pessoa, são naturaes e infalliveis.

A 14 de Junho do mesmo anno ás 10 horas da manhã foi o Senhor Bispo na sua liteira á Sé, e apeando-se entrou pela porta principal, onde o Cabido o esperava, porque o Senhor Bispo na espera o tinha mandado avisar, e depois de têr feito oração na Capella do Santissimo Sacramento dirigiu-se com elle á Aula Capitular, onde declarou que vinha agradecer ao R. ${ }^{\text {mo }}$ Cabido as demonstrações, que tinha feito, e que esperava merecêlas na boa harmonia, e que desejava ter com o R.mo Cabido, e ratificou o juramento, que o seu Procurador tinha prestado no acto da sua posse. 


\section{Miguel de Anunciação}

\section{Fundação do Seminário}

Na Carta, que o Ex. ${ }^{m o}$ Sr. Bo C.de D. Fr. Alvaro de S. Boaventura escreveu aos Eminentissimos Cardeais em 3 de Junho de 1675, diz. Em esta Cidade não fizerão os Bispos Seminario por haver nella uma tão insigne Universidade onde se ensinão todas as sciencias; mas ainda assim tem os Bispos duas Cadeiras de Theologia Moral, que pagão das suas rendas e bem os Padres da Companhia de Jesus no seu Collegio das Escholas menores e no Claustro Sé uma Cadeira de Gramatica.

Foi este zeloso Prelado o Fundador do bello Seminario, que é presentemente um dos mais notaveis ornamentos da Cidade de Coimbra. Não pensemos porém que a Diocese estivesse até então desprovida de caza, na qual se désse educação e instrução aos Ordinandos, pois já em 1741 existião defronte do Collegio do Loios em Coimbra umas Cazas que servião de Seminario, pois quando nesse anno se tractou das Corporações que havião de formar a Procissão de acompanhamento ao Ex. ${ }^{\text {mo }}$ Sr. Bispo Conde na sua entrada publica e solenne, o D.or Provisor do Bispado deu ordens ao Seminario para que tomasse parte no acompanhamento. Depois o Sr. Bispo Conde em 1743 removeu este Seminário para a Freguesia de S. Martinho do Bispo para uns cazarões, aos quaes o povo da dicta Freguesia deu o nome de Seminario Velho.

a este Seminario que se refere S. Ex.a quando na sua Provisão de 19 de Dezembro de 1754 diz, que erigia a Congregação dos pios Operarios, porque a experiencia de onze annos que tinha começado o seu seminario lhe mostrava a necessidade da creação deste Instituto.

Nos dictos Cazarões reunirão-se tantos seminaristas, que começarão a viver apertados e incommodados, e portanto manifestou-se a necessidade de constituir uma Caza ampla, onde podessem estar á vontade Mestres, Ordinandos e Porcionistas; lembrou-se pois S. Ex." de fundar essa Caza nos surburbios da Cidade, e deu-lhe principio em 1748 .

Que fundos poderia ter a Ex. ${ }^{\text {ma }}$ Mitra em 1741 para acometter a fundação do Seminario em 1748 ?

Sendo a Diocese de Coimbra em 1741 tão vasta, que durante a prisão do Ex. ${ }^{\text {mo }}$ Sr. Bispo Conde se desmembrarão d'ella 72 Freguesias para se formar o Bispado de Aveiro (elevada a cid.e em 1774) e 19 forão adjudicadas ao Bispado da Guarda, já se vê que a somma dos rendimentos da Ex. ${ }^{\text {ma }}$ Mitra devia elevar-se a uma grande cifra de mil cruzados: e dizendo S. Ex. ${ }^{a}$ na sua Apologia, que dos Livros das rendas da Mitra constava, que a receita nos 8 annos da sua prisão fôra de quinhentos, e trinta mil, e cincoenta e seis cruzados e a despeza que se fez, e a Mitra era obrigada, somava trezentos e sessenta e três mil duzentos e cincoenta cruzados, e que passava a receita pela despeza cento e ses-senta seis mil, e oitocentos cruzados, mas que não encontrara dinheiro algum, antes algumas dividas, podem m.to bem os rendimentos da Mitra sêr calculados em sessenta mil cruzados annuaes, e deduzindo d'elles metade para a Congrua dos Vigarios Capitulares, e para as despesas, que a Mitra era obrigada a fazêr, ainda ficava outra metade, a real no espaço dos 20 annuos de vacatura dava a somma de seiscentos mil cruzados.

Com tão avultado fundo já o zeloso Prelado poderia metter mãos à empresa da fundação do Seminario; alem disto dirigiu Pastoraes em 25 de Abril de 1749; aos R.dos Parochos para exhortarem os Fregueses a contribuirem com a sua esmola: El Rei mesmo man- 


\section{Marquês : de 'Pombial}

dou ajudar a Construção da Obra subministrando madeira do Pinheiral de Leiria, e até do Brasil, da qual se conservou um pequeno depósito.

Mandou vir Architectos da Italia, quaes forão João Francisco Famosi (ou Tamosi?) e Jacome Azolini e bem assim riscos de Seminarios já existentes na Italia: Abrirão-se os alicerces em 22 de Junho de 1748 , e a 16 de Julho assentou-se a $1 .^{\mathrm{a}}$ pedra, funcção á qual foi assistir o seu fundador e fôram tambem muitas pessoas, e entre estas o Sr. Francisco de Lemos então Estudante, e depois seu sucessor.

Terreno, onde foi fundado o Seminario. Lembrou-se o Ex.mo Sr. Bispo Conde de fundar o Seminario no suburbio da cidade inclinado para Sudeste e Sudoeste, caminhando para a Arregaça, e Alegria, junto ao Campo da Genicoca ou monte aureo assim denominado por causa das muitas flores amarelas chamadas pelo pôvo mal mequeres, que ahi nascião, e onde estava já fundado o Convento dos Carmelitas descalços (vulgo - S. José dos Marianos, que deu o nome ao bairro) e perto do Convento de S.ta Anna da Ordem de Santo Agostinho.

Este terreno estava todo plantado d'oliveiras; que formavão 7 olivaes pertencentes a differentes donos; estes olivaes forão todos comprados pela quantia de 445.000 cr á excepção de dous, que forão dados, a sabêr - o de Jose Ramalho d'Oliveira Catana, e sua mulher D. Anna Ygina Arnaut, e o de Francisco Collaço da Silveira, e um que era prazo da Collegiada de S. João d'Almedina, e que esta aforou ao Seminario por 4 alqueires d'azeite as saffras.

\section{Pastoral de 25 de Abril de 1749}

Provisão do Ex. ${ }^{\text {mo }}$ Sr. Bispo Conde D. Miguel da Annunciação com data de 25 d'Abril de 1749, na qual manda aos R.dos Parochos, que exhortem os seus Fregueses a Concorrerem com esmolas para a factura do Seminario.

D. Miguel da Annunciação

A todos os nossos subditos d'este Bispado assim Ecclesiasticos como Seculares, saude e paz para sempre e em Jesus Christo Nosso Senhor, o Salvador. Faremos saber que considerando Nós a grande utilidade espiritual e temporal, que hade resultar a este Bispado de nelle se erigir um Seminario, ou Collegio para educação de meninos pobres e de pouca idade, que sendo a elle recolhidos possam ser bem instruidos em virtudes e lettras, donde saindo nellas consummados e perfeitos Nos possão ajudar na cultura da vinha, que o Senhor foi servido commetter Nos, e attendendo juntamente não só na factura da dicta Obra, mas tambem na sustentação dos mesmos Meninos, e de Seus Mestres, e mais superiores, que hão de regêr e governar, se hão de fazer grandes despezas por isso que Nos não é por ora possivel constituir rendas e só se poderão supprir pela piedade, e zelo dos Fieis concorrendo todos com aquellas esmolas que commodamente pudessem dar capacitando-se, que a dicta erecção será muito do agrado de Deus, e que alli será Sua Divina Magestade servido e louvado com perfeição, e com proveito e espiritual dos nossos Diocesanos, pois recolhendo-se ao dicto Collegio os Meninos pobres d'elle sairão bem morigerados, e instruidos em virtudes e lettras sem estipendio de seus Paes, e parentes, e com esperanças certas de serem por Nós preferidos nos provimentos dos Beneficios e Egrejas da nossa Apresentação, e das maes que em qualquer tempo nos pertencem provêlos de Parochos. E como não podemos vivamente representar a cada hum de por si estas razões e outros sinaes que nos movem a dar principio á dicta Obra, e erecção do dicto Seminario nesta Cidade, recommendamos, exhortamos e man- 


\section{Miguel da Anuncią̧ão}

dados a todos os R.dos Parochos, deste nosso Bispado, e a cada um de por si que sendolhes esta apresentada, logo no primeiro Domingo, ou dıa Santo, a leião e publiquem na Estação da Missa de Terça aos seus Fregueses, exhortando-os e propondo-lhes o quanto será do agrado de Deus Nosso Senhor, e utilidade sua propria concorreram com as suas esmolas para a factura do dicto Seminario e sustentação dos taes Meninos e as utilidades, que da dicta Obra resultão a cada um d'elles pois sem outro algum dispendio os verão crescidos nas virtudes e lettras com grande gosto de seus Paes e parentes. Pelo que cada um dos R.dos Parochos respectivamente nos Logares das suas Freguezias elegerão uma ou duas Pessoas Eclesiasticas, zelosas que no tempo do recolhimento das ofertas e ainda nos dias Santos e Domingos do anno hajão de pedir as dictas esmolas, e quando houverem de se metter os seus roes de confessados farão conta com individuação da importancia d'ellas, tantos das que se tiraram pelas suas Freguesias, como daquellas com que concorrerem as Confrarias [riscado] do que voluntariamente quiser dar cada um dos mesmos R.dos Parochos ou outras pessoas particulares, que por sua devoção queiram contribuir para a dicta Obra, fazendo entregar tudo o que assim se der no dicto Seminario á pessoa, que ahi por Nós se achará deputado, a qual fará Livro rubricado pelo Nosso R.do Provisor [riscado] D.or Provisor, em que assentará com toda a distinção, e clarêza as esmolas de cada uma das Freguesias para d'ellas Nos dar conta em cada um dos annos dentro do tempo, que para isso lhe determinarmos. E recommendamos m.to aos R.dos Parochos queirão pôr todo o cuidado nesta recomendação a seus Freguezes, para que insitados do amor de Deus, e de seu proprio interesse hajão de satisfazer ao que muito lhe recomendamos nesta nossa Provisão que valerá, e sortirá seu effeito em quanto nao Mandamos o contrario. Dada em Coimbra sob Nosso Signal e Sello de Nossas Armas aos 25 d'Abril de 1742. E eu Leandro Marques de Miranda, Escrivão da Camera Ecclesiastica a subscrevi: - D. Miguel Bispo Conde - Lugar + do sello.

Foi publicada, e impressa esta mesma Pastoral em 24 de Abril de 1763, e sobscripta por Luís Pereira de Lima, Escrivão da Camera Ecclesiastica, e assignada pelo Sr. D. Miguel, e no verso tinha tambem impresso o seguinte aviso. Attendendo o Ex. ${ }^{\mathrm{mo}} \mathrm{Sr}$. Bispo Conde á grande utilidade que se segue da erecção do Seminario, e á Consideravel despeza que se faz precisa para a sua Construção me ordena avise a V. M.cê para que estes seus Freguezes na Estação da Missa de Terça para que com todo o zelo e Caridade hajão de concorrer com as esmolas que lhes forem possível na forma da Provisão retiro, e com o Rol dos Confessados se metterá V. M.ce um Cruzado de toda a Confraria, Irmandade e Fabricas, que costumão dar contas neste Juizo, e cazo que haja alguns Mordomos Rebeldes Contra elle procederá V M.cê na forma da Ordem geral da Visita. Coimbra, d'Abril 24 de 1763.

Manuel Rodrigues Teixeira.

\section{Em quantas partes era dividida a Obra?}

A obra era dividida em duas partes; uma para Ordenandos, Exercitantes, e Hospedes; e outra para Seminaristas e Porcionistas; a estas partes davão o nome de braços, um dos quaes ficava para a banda do rio ou do noroeste, e outro para a banda do nascente: o do noroeste cra para Seminaristas e Porcionistas; e neste foi edificada a Capella de Nossa Senhora de Annunciação; o outro braço (o do nascente) era 


\section{Miguel da Anunciação}

para Ordinandos; Exercitantes e Hospedes e neste foi edificada a $\mathrm{Ca}$ pella de S. Miguel.

Em Septembro de 1758 estava acabada só metade da obra. Em 1761 já se tinhão gasto cento, e sessenta e seis mil cruzados e duzentos e oitenta mil trezentos e cincoenta e oito reis. Dizem, que se concluira em 28 de Outubro de 1765.

Estatutos do Seminario Episcopal. Como o Seminario estava funccionando na Freguesia de S. Martinho, o Ex. ${ }^{\text {mo }} \mathrm{Sr}$. Bispo Conde tratou de Ordenar Estatutos para elle em 1748.

$\mathrm{Na}$ Imprensa de R. Camera Apostolica em Roma imprimiram-se as Lettras Apostolicas em forma de Breve, que expediu o SS. ${ }^{\text {mo }}$ P.e Benedicto $14 .^{\circ}$ para Confirmação dos Estatutos do Seminario Episcopal de Coimbra, os quaes em summa prudencia ordenára o Bispo moderno D. Miguel da Annunciação, Fundador do mesmo Seminario, e propôs à Santa Sé Apostólica para que os visse e approvasse. A estes Estatutos deu-se o nome de - Constituições do Seminario Episcopal de Coimbra.

O Breve diz no fim - Dado em Roma em Santa Maria Maior aos 18 de Dezembro de 1748 no $8^{\circ}$ anno do nosso Pontificado (Benedicto $14 .^{\circ}$ tinha sido elevado ao Pontificado em 1740).

O Breve veio de Roma em Latim e começava pelas palavras - Romanis Pontificibus - foi cá traduzido em Portuguez, e a tradução foi approvada pelo Sr. Bispo Conde em 3 de Julho de 1760, dizendo: Approvo esta tradução. Seminario de Jesus Maria Jose, 3 de Julho de 1760, D. Miguel Bispo Conde.

No $1 .^{\circ}$ de Novembro de $1754 \mathrm{fez}$ o Sr. Bispo Conde os primeiros Additamentos aos Estatutos; e foi quando erigiu a Congregação dos pios Operarios, e lhes entregou o Seminario. Em 19 de Janeiro de 1759 fez-lhes novos Additamentos. Seminario?

Quem erão os Padres que exercião as funç̧ões do Magisterio no diante.

A este respeito não achámos noticias senão do anno de 1748 por

Em 1748 losophia.

O P.e João Baptista Darquié, Francez de naçaõ, ensinava Phi-

O P.e Luiz Marques, do Bispado de Leiria, ensinava Grammatica. Ausentou-se pelo Natal.

Além destes estavaó

O P.e Bernardo Francisco de Mattos, de Vallerim.

O P.e Manuel Jose Quaresma.

O P.e Jose António Cerveira, de Vacariça.

Entrarão Ordinandos, Porcionistas e Convictores

Em 1749

1 - O P.e Ignacio Jose Gomes, de Coimbra, Presidente de Moral.

2 - O P.e José Simões, de Poiares, Mestre de Cerimónias e de Cantochão.

3 - José Felix Nogueira, de Lisboa, ensinava Latim.

4 - António Simões da Cruz, do Barrô.

5 - João António de Sousa Negrão, de S. Silvestre.

6 - Marcellino Rodrigues Ramalho, de Lavos.

7 - José Suares Barbosa, de Villa Cova do Pourinho.

8 - Anacleto de Figueiredo, de Villa Cova a Coelheira. 


\section{Miguel da Anunciaģão}

9 - José Joaquim de Barros, de Abiul.

10 - Freire Suares de S. Lazaro, de Ancião.

11 - António de Sousa Meneses de Lemos, de Agueda.

12 - Manuel dos Santos Innocente Reis,

13 - Eusébio Custódio das Neves, de Oliveirinha.

14 - Manuel da Fonseca, de Nogueira.

Em $1750-1751$

Darquié, na cadeira de Philosophia.

$\cup$ P.e António da Costa Pacheco, Mestre de Moral.

O P.e Manuel Gomes Girão, Prefeito.

O P.e José Simões, no mesmo Emprego de Mestre de Cerimónias, e Canto chão.

O P.e José Quaresma, Prefeito.

O P.e Manuel de Oliveira, Mestre de Grammatica.

Em 1751 - 1752, faz-se mençaō

Reitor - D. Nicolau Giliberti, o qual era natural de Saponara pequena Cidade do Reino de Nápoles. Dizem que viera de Roma na Companhia do Núncio para a Hespanha, e d'ahi passára a Coimbra, onde se relacionara com o Sr. Bispo Conde, que o nomeou Reitor do Seminario.

- Girão

- Pacheco

- Simões

- Quaresma

- Antonio Carneiro Vargas, Mestre de Grammatica.

(N.B.) Não se faz mençaõ do Darquié, nem do Oliveira.

Em $1752-1753$

Faz-se mençaõ de

Reitor - D. Nicolau Giliberti

- Simões

- Pacheco (Desembargador)

- João Verdié, Francez de Naçaõ, Mestre de Philosophia.

- Quaresma

- Vargas

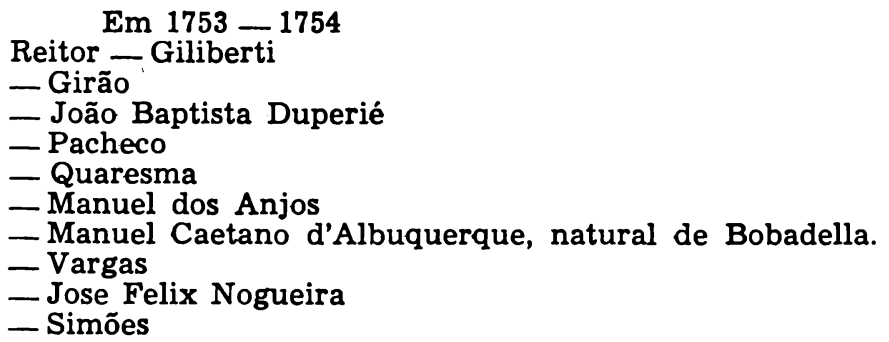

Em $1754-1755$

Reitor - Giliberti

- Girão

- Duperié

- Pacheco

- Manuel Francisco dos Anjos

- Manuel Feliciano da Silveira, natural de Maçãs de D. Maria.

- Bernardo Alves Ferreira, natural d'Albergaria. 


\section{O Marquês de Pombal}

- Vargas

- Nogueira

- Quaresma

- D. Thomas Hossenaldes, Hespanhol, natural do Logar de los Novaros do Arcebispado de Saragoça no Reino d'Aragão, Sacerdote da Congregação dos pios Operarios do mesmo Reino, mandado vir pelo Ex. ${ }^{\text {mo }}$ Sr. Bispo Conde.

Ereç̧aб da Congregaçaõ dos pios Operarios em Dezembro de 1754

Conquanto só em 1758 é que se concluisse metade da Obra do Edificio do Seminario, entretanto os Seminaristas, que vivião em S.Martinho, requererão ao Ex. ${ }^{\text {mo }}$ Sr. Bispo Conde em 19 de Dezembro de 1754, que erigisse a Congregação dos pios Operarios, e lhes entregasse o Seminario de Coimbra.

Os Padres, que assignaram este Requerimento fôram:

D. Nicolau Giliberti - Reitor

D. Thomas Rossemaldes, Missionário Apostólico

Manuel Francisco dos Anjos

Manuel Gomes Girão

Manuel Feliciano da Silveira

O Ex.mo Sr. Bospo Conde despachou affirmativamente regulando-se pela Bulla - Militantis Ecclesiae - do Santo P.e Clemente 12. confirmada por Benedicto $14 .^{\circ}$ (e que teve o beneplacito em 28 de Junho de 1779), S. Ex. na Provisaõ, que para este effeito mandou passar, diz logo no principio, que a experiencia de onze (11) annos, que se tinha dado principio ao Seu Seminario lhe tinha provado a grande necessidade de erigir esta Congregação por ser difficultoso achar Sacerdotes doutos, e pios, que queirão assistir nelle, e trabalhar em ensinar. e educar na Disciplina Ecclesiastica os alunnos, Convictores, e Ordinandos, por serem rarissimos aquelles que - non quaerunt quae sua sunt sed quae Jesu Christi, e que por este motivo tomara a resolução de mandar vir ao Reino d'Aragão um d'aquelles pios Sacerdotes. cujo instituto é trabalhar em instruir os alunnos e Ordinandos nos Seminarios, dar exercicios espirituaes ao Clero, e fazer Missoes.

Posse em 23 de Dezembro de 1754

No dia 23 deDezembro de 1754 foi o Ex.mo Bispo Conde com o Notario Pe Francisco da Silva dar posse do Seminario aos dictos P.es Operarios. entregando as chaves ao Reitor, o qual depois de prometter cumprir bem. e fielmente as obrigaçōes do seu Cargo abriu e fechou as portas da Igreja e do Seminário, e andou e passou por elle. Foram testemunhas o architecto do Seminario João Francisco Famosi. e o Seminarista Boaventura Francisco da Piedade.

S Ex. requereu a Sua Santidade Benedicto $14 .^{\circ}$ lhe confirmasse a erecção da Congregação dos pios Operarios e a união do Seminario a ella. e Sua Santidade assim o fez pelo Breve - Exponi nobis - de 10 de Março de 1755

Só em 7 de Junho, de 1757 é que os pios Operarios fizeraõ voto na Igreja do Seminario nas maõs do Ex. ${ }^{\text {mo }} \mathrm{Sr}$. Bispo Conde declarando cada um a sua naturalidade pela ordem seguinte -

O Reitor - D. Nicolau Giliberti, natural da Cidade de Saponara no Reino de Napoles.

José Simões, natural de S.to André de Poiares, ficou logo com o título de Ministro.

Manuel Gomes Girão, Primeiro Prefeito do Seminario, natural da Povoa de S.ta Christina. 


\title{
D. Miguel da Anunciação
}

D. Thomas Hossenaldes, natural do Logar de Villar de los Novaros do Arcebispado de Saragoça, no Reino de Aragão. Missões.

Francisco da Costa Pereira, natural do Logar de Marosa, Freguesia de S. Mamede de Villa Verde no Arcebispado de Braga.

Manuel Caetano d'Albuquerque, natural de Bobadella do Bispado de Coimbra.

João Rodrigues d'Oliveira, natural de S.to André de Poiares.

António Saraiva Pereira, natural do Logar de Amancede, Freguesia de Vallongo, Ministro e Boticario.

Francisco da Cunha, natural de Sandomil: com o título de Irmão.

Em 25 de Janeiro, e em Fevereiro de 1758 - fizeraó votos outros mais padres na Congregação /

Arquivo do Seminário de Coimbra, Documentos Vários

\section{SOBRE AS VISITAÇÕES DA DIOCESE}

\section{S. M. S.}

\author{
Copia da Provisão \\ q o Ex. ${ }^{\mathrm{mo}}$ S.r $B$. $^{\circ}$ \\ Conde foi servido \\ passar ao R.d d $^{\text {Dor }}$ visitador \\ de vouga e Seu secretario -
}

Dom Miguel da Annunciaçao Conego Regular de Santo Ag. ${ }^{\circ}$ da congregaçao Reformada de Santa Cruz por mercê de Deus e da Santa See Apostolica Bispo de Coimbra, Conde de Arganil, senhor de Coja e do Cons. ${ }^{\circ}$ de Sua Mag. ${ }^{\circ}$ etc.

Aos q a prez.t ${ }^{\circ}$ nossa Provisão virem saude e paz p. ${ }^{a}$ sempre com JESUS Christo nosso Salvador. Fazemos saber q movidos Nos da autorid..$^{\circ}$ dos Sagrados Canones, detreminação do Sagrado Conci. Trid. e taobem da Razaõ de nossa Pastoral cuid..$^{\circ}$ e vendo que o anno passado, se começaram as visitas dos Arcediagados de vouga e Penella deste nosso Bisp. d $^{\circ}$ e q se naõ findaraõ, nem se pode nellas continuar até o presente por justos motivos naõ cessarao e agora, por graves e legitimas ocupacoiz que requerem a nossa vigil. ${ }^{a}$ Episcopal naõ podemos por nos pessoalmente vizitalos nos deliberamos em eleger pessoas Eccl. ${ }^{\text {as }}$ de conhecida letras virtude e prud. ${ }^{\mathrm{a}}$ a $\mathrm{q}$ hajamos de commetter as d. ${ }^{\text {as }}$ vizitas $q$ as possaõ acabar de fazer inteiramente e desta sorte satisfazemos q.to nos he possivel a nossa pastoral obrig. am no detreminado pelo mesmo Concilio;

Por tanto á vista da boa informação q temos da pessoa virtude prud. ${ }^{a}$ e Letras do R.d d $^{\circ}$ Bento da Fonseca Correa Dez.or da Meza Episcopal, e confiando delle q em tudo obrará com ascerto q convem ao ser..$^{\circ}$ de Deos e nosso e á utilidade de nossos subd. ${ }^{\circ}$ e q satisfará inteiram. a Sua obrig.am e q fará tudo o que por nos lhe for mandado e comettido; Havemos por bem de o nomearmos e elegermos por vizitador do Districto do Acediagado de Vouga este anno de 1741. p. ${ }^{\mathrm{a}} \mathrm{q}$ haja de acabar a vizita delle naquella $p .^{\circ} \mathrm{q}$ aind anaõ foy vizitada $\mathrm{e}$ podera vizitar todas as Igrejas asim Mayores como Menores Parochiaes Collegiadas, capellas oratórios e taobem as Igr. ${ }^{\text {as }}$ parochiaes junctas por dir.' de uniaó aos mosteiros izentas è aos Sacèrdotes e clerigos dellas asim seculares como Regulares q nos mesmos Most.ros e Ig. ${ }^{\text {as }}$ tractao da cura dellas pelo q toca a cura parocial e administraçao dos Sacrma. se bem asim a todas as pessoas não so Eccl.as mas outras quaisquer 


\section{O Marqués de Pombal}

que estejaõ entregues a nosso cuid. ${ }^{\circ}$ procurando em prim..$^{\circ}$ lugar satisfazer com m.ta delig. a a $q$ for mais do agrado de nosso $S .^{r}$ e bem das Almas, exhortando a todos com practicas saudaveis e advertindolhes o q devem obrar p. discargo de suas consiencias $p .^{a} q$ asim tudo vá dirigido ao cam. ${ }^{\circ}$ da charid. ${ }^{\circ}$, Religiaõ Catholica e Santa Doutrina advertindo as com saudaveis razois $q$ hajao de dizer e de annunciar tudo o q souberem dos itens e interogat. o contheudos e Apressados no Edital da vizita que se hade publicar em cada huma das freg.a sem odio nem affeiçaõ mas sim com os olhos em Deos e na charid. do proximo; inquirirã com todo o cuid..$^{\circ}$ pelo culto e veneraçaó q se deve aos lugares sagrados e seos Parochos e mais pessoas q estao a seo cargo e cuidao do culto delles e administrao os sacram. . $^{\circ}$ a seos Fregueses e se tem cuid. ${ }^{\circ}$ de os excitar ao exercicios espirituaes e procurar quanto ensino ha a salvaçaõ das Almas fazendolhes doutrinas e observandoos no amor a Deos e charid. do proximo e se em tudo e por tudo fazem a sua obrig. ${ }^{\text {am }}$ como verdadeiros Parochos e Pastores do Rebanho de nosso S.or JESUS Christo por dispensaçaõ do mesmo S.or lhes foi entregue. E tambem inquirirã dos q nos templos estaõ conversando sem q seja em pias practicas conducentes ao frevor em Deos e se inteiram. dao o culto devido aos dias de Festa nao trabalhando ou exercitando se em couzas taes q dellas resulte offensa a Deos Ds. nosso Senhor; exeminará outrosim o culto e aseyo da Igr. ${ }^{\text {as }}$ e sua fabrica interior e exterior olhando com cuid. ${ }^{\circ}$ pelaz capellas, Altares, Baptisterios e Sacrarios, oratorios e mais cousas a ellas pretencentes como vestimentas vazos sagrados ornam. ${ }^{\circ} \mathrm{e}$ outras quaisq. ${ }^{\mathrm{r}}$ alfaias eccl. ${ }^{\text {as }} \mathrm{p} .{ }^{\mathrm{a}} \mathrm{q}$ em tudo seja tractado o culto Div. ${ }^{\circ}$ com o aseyo e decencia q convem p.* a que tudo lhe damos e concedemos todos os nossos poderes e lhes

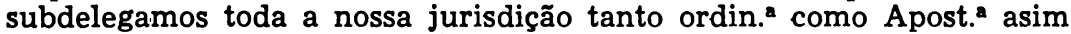
e da mesma forma $q$ vos hé concedida pelos Decretos Pontif.os Dir. ${ }^{\circ}$ Canonico e pelo q.al Concil. Frid. ou por quaisq. ${ }^{\text {. Synodos Provinciaes }}$ ou Dyocesanos ja prescriptos de nossas vizitas e ainda pela vizita Ap.c p. q asim se possaó augmentar e favorecer os bons costumes, reprimir os máos extripar os vicios semear as virtudes e emendar os pecadores mostrando em tudo cumprir quanto em si ha com a nossa obrig. ${ }^{\text {am }}$ pastoral como delles esperamos e como se lhe assinaraó outenta mil Reis de ordenado pelo trabalho da vizita de todo o Arcediag. ${ }^{\circ}$ attendendo a alguas justas cauzas $q$ houver $p^{\bullet} q$ asim se lhe assignassem $e$ ja houve pela p." q tem vizitado quarenta mil Reis havemos outrosim por bem q pela p.a q agora vay vizitar se lhe dem outros quarenta mil Reis por esta vez somente q haveraõ no fim da vizita Rendas da nossa Mytra vizitado o d..$^{\circ}$ Arcediagado; e p..$^{\circ}$ Secret. $^{\circ}$ da mesma vizita lhe damos

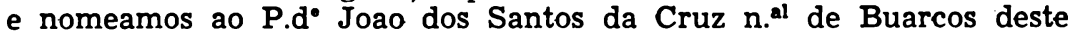
Bisp. $^{\circ}$ e ambos prim. ${ }^{\text {ro }} \mathrm{q}$ entrem a servir as d.a ocupaçois com $\mathrm{q}$ pos Nos Elleitos haveraã da nossa mam ou do nosso R.d' D.or Provizor o juram..$^{\circ}$ dos Santos Evang..$^{\circ}$ de bem e verd. $.^{\text {ra }} \mathrm{m} . \mathrm{t}^{\bullet}$ as exercitarem de $\mathrm{q}$ se extendera termo de juram. ${ }^{\circ}$ nas costas desta $q$ valera som. ${ }^{\circ}$ por esta vez e o R.d ${ }^{\circ}$ Secret. $^{\circ}$ trasladara logo esta no principio da devaça $p$. $^{2}$ a todo o sempre constar do refer. ${ }^{\circ}$; Dada em Coimbra sob nosos sinal e sello de nossas Armas aos 5 de julho de 1741 e Eu Leandro Vasques de Miranda Escrivaõ da camara Eccl." a sobrescrevi.

\section{Miguel B.॰ Conde}

A. U. C., Visitaçōes do Arcediagado do Vouga, Parte I (1741), fls. 4-6 v. ${ }^{\bullet}$ 


\section{O Marques de Pombal}

\section{X - D. MIGUEL DESTITUfDO DO CARGO DE BISPO DE COIMBRA}

(9 de Dezembro de 1768)

Deam, Dignidades, e Cabido de Santa Igreja Cathedral de Coimbra. Eu ElRei vos envio m.to saudar. Porquanto o Bispo D. Miguel da Anunciação, depois das minhas Leis de 6 de Maio de 1765, de 2 e 5 de Abril deste prezente ano, Levantando-se manifesta, e publicamente contra ellas, espalhou nesa Dioceze, e nesta Corte debaixa de simulados titulos diferentes papeis sediciozos, e ofensivos dos mesmos sagrados Direitos da minha Coroa, e do socego publico, fazendo-os clandestinamente pasar ás maôs dos Parrochos p..$^{\circ}$ ilaquearem as consciencias dos seus respectivos freguezes naõ só sem conhecimento algum meo, e sem preceder o meo consenso, e real beneplacito, que era o que bastava, mas tambem inventando $\mathrm{m} . \mathrm{t}^{\circ}$ pelo contrario, para dele fugir, a dezuzada ideia de espalhar ultimamente manuscrita a intitulada Pastoral de 8 de Novembro proximo pasado, contra o geral costume daquele, e dos mais Bispados, segundo o qual naõ podia correr a dita Pastoral, senaõ havendo sido estampada com previa aprovaçaõ minha, p. assim se evitarem absurdos, ainda menores, do que os inauditos, em que nela se deslizou o dito Bispo; Porquanto o mesmo Bispo pela compozição ou adopção, uzo, e dispersão da sobredita Pastoral, e pelos abominaveis e notorios crimes de Leza Magestade, que nela, e na sua clandestina dispersaõ acumulou desde a concepsaó dos sobreditos factos na dispoziçaó das referidas Leis, e entre elas especialmente na de 6 de Abril, que estabeleceo contra os transgressores dela / qual foi o dito Bispo / as penas da minha Real, grave indignação, da confiscação de todos os seus bens p. a minha Camara, da privaçaó da naturalidade nestes meus Reinos, e Dominios, p. ${ }^{a}$ mais naó gozar das Onras, e utilidades, de que gozaõ os Vasalos deles, e das mais penas estabelecidas contra os que conspiraõ ou p. a $^{\mathrm{a}}$ as ofensas da minha Regia Magestade, ou p. as ruinas dos meus Reinos, e estados, ou p.a a perturbação do publico socego executando-se irremisivel e cumulativamente as sobred. $^{\text {a }}$ penas contra os transgressores em todos, e em cada um dos cazos determinados, sem que seja necesario que todos eles concorraó copulativamente: Porquanto pela natureza dos referidos crimes de Leza Magestade, e como tais excluzivos de todo o privilegio, e foro do meu Regio, e imediato conhecimento, pelo menisterio da m. ${ }^{a}$ Lei, e pela notoriedade dos mesmos crimes, ficou o referido Bispo incurso nas sobreditas penas desde a hora, em que os cometeo sem necesidade de se esperar p. ${ }^{\mathrm{a}}$ iso sentença, porquanto desde que o mesmo Bispo caio debaixo das mesmas penas, foi reputado por morto, e o governo dese Bispado vago, e orfão de proprio Pastor, que posa dirigilo, em consideraçaó de tudo o referido, como Protector que sou dos meus Reinos e Dominios, conforme o Concilio de Trento, me pareceo significarvos como por esta significo, que na forma do mesmo Concilio devo constituir Vigario Capitular que governe o dito Bispado com concesaõ de toda a jurisdiçaó sem rezerva alguma emquanto naõ houver Legitimo Prelado Diocezano, e porque tenho boa informação das Virtudes, Letras e mais predicados de Francisco de Lemos e Faria Dezembargador da Caza da Suplicação, Juiz geral das Ordens, Deputado do S.t' Oficio da Inquizição me será muito agradavel, que façais eleiçaõ da sua Pesoa p. o referido emprego, por confiar dele, que cumprirá muito exactamente com as obrigaçoens do dito cargo. de 1768 .

Escripto no Palacio de Nosa Senhora da Ajuda a 9 de Dezembro

\section{Rei}

P.a o Deam, Dignidades, e Cabido da Santa Igreja Catedral de Coimbra. A.U.C., Documentos Avulsos 

BISPADO, P.A O QUAL PARTIO DE LX.A NO DIA 11 DE AGOSTO DE 1777.

No dia 11 de Agosto pelas 3 horas da tarde sahio o Snr. B. ${ }^{\circ}$ Conde da Caza de seo sobr. ${ }^{\circ}$ o Ex. ${ }^{\text {mo }}$ Conde de Povolide com a piquena comitiva de quatro carruagens, que levavão a Sua Pessoa, e familia. Este Prelado convidou p. a sua companhia, e carruagem ao P.e Fr. Joze Caetano que por ordem expressa de Sua Mag.e hia p. ${ }^{a}$ o convento do Louriçal donde fora removido na tempestade de 9 de Dezembro do anno de 1768, sendo extraordinario Confessor deste famozo Santuario. Dirigio-se a jornada a Mafra por Bellas p. ${ }^{a}$ vezitar em despedida ahi mesmo o Secretario de Estado Aires de Sa e Mello, que estava apozentado no Palacio, e Quinta do Ex. ${ }^{\text {mo }}$ Conde de Pombeiro, p. ${ }^{\mathrm{a}}$ mais facilm.te assistir a Sua Mag. ${ }^{\circ}$ na rezidencia de Queluz. Recebeo aquelle Ministro ao Prelado com grande politica, acompanhando-o athe recolher-se na sua carruagem. Pelas 11 horas, e hum quarto da noite chegou a Mafra, aonde passou o dia seguinte, recebendo fraternais obzequios da sua amada Communidade. Ahi se achava o Ex. ${ }^{\text {mo }}$ D. Mart. ${ }^{\circ}$ Mascarenhas, Marquez que he de Gouvea, e f. ${ }^{\circ}$ Primogenito do infeliz Duque de Aveiro. Distinguio-se m.to nos obzequios do Ex. ${ }^{\text {mo }}$ B. ${ }^{\circ}$ aquelle bem instruido, amado, e agradavel Fidalgo, que soube tirar, e trazer da sua recluzão as mais belas qualid. ${ }^{\text {es }}$ de hum Cavalheiro Christão: deveo a D..$^{\mathrm{s}}$ a sua indole, e a hum bom $M .^{\circ}$, q teve na sua prizão, a educação, que o faz merecedor de toda a attenção, e fortuna, $q$ conseguiria na boa Conservação de seo Pai; elle se chama disgraçado, e elle deve á sua disgraça a occazião de se fazer ainda mais benemerito pelas suas virtudes.De Mafra, sahio o Prelado p. a Quinta dos Lapas, aonde o esperava o Ex. ${ }^{\text {mo }}$ Marquez de Penalva com todaa sua Familia, e os Ex. ${ }^{\text {mos }}$ Condes de Tarouca. As honras, com que esta illustrima Caza estimou a Vezita do Prelado, forão extraordinarias com as maiores demonstraçoens de huma sincera estimação das suas virtudes, e restituição. No dia seguinte, q' forão 14 de Agosto, se continuou a jornada athe as Caldas,aonde tiverão huma amoroza contenda os Ex. ${ }^{\text {mos }}$ Marquez do Louriçal, e Conde de Rezende, sobre qual havia de ter a felicid. ${ }^{\circ}$ da companhia de Sua Ex. ${ }^{\mathrm{a}}$ em sua Caza; prevaleceo o de Rezende pela prevenção, e pelo parentesco. Ahi passou o Ex. ${ }^{\text {mo }}$ Prelado a tarde do mesmo dia 14; e ouvio Missa no dia 15, e partio de manhã p. a Nazareth, aonde chegou depois do meio dia, e se dilatou ahi mesmo nessa tarde. Foi vezitar o devoto Santuario da Snr.a; aonde os Eccleziasticos a coro o esperavão com recebim t $^{\circ}$ solemne, Repiques, e multidão de povo. Cantou-se na Igreja huma Ladainha acompanhada de Orgão, e sahio S. Ex. a vezitar a Capella da Memoria. Em todo o tempo da jornada forão abundante sas Esmollas pelos cam. ${ }^{\text {B }}$, e Povoaçoens, não se negando já mais esmola competente a $\mathbf{q}^{\mathrm{m}}$ a pedia. p. $^{\mathrm{a}}$ o que hum Conego da sua familia tinha especial commisão, e providencia. Continuou-se a ornada p. ${ }^{a}$ Leiria no dia 16 pela manhã. Em todos os dias fez S. Ex." celebrar Missa, que ouvia, ou antes de partir, ou em alguma Capella no caminho. Porque achou huma menos preparada, ordenou ao Paroco, que mandasse hum proprio ao Louriçal a buscar Corporais mais dignos do Sacrificio. Meia Legoa antes q' entrasse em Leiria esperava o Ex.mo B. ${ }^{\circ}$ D. Fr. Miguel de Bunhoens, e o melhor da sua Cathedral ao Ex ${ }^{\text {mo }}$ B. ${ }^{\circ}$ de Coimbra. Foi honrozo. e respeitozo o encontro dos dois Prelados e sua illustre Comitiva. O Ex. ${ }^{m o}$ B. ${ }^{\circ}$ de Leiria convitou o Ex. ${ }^{\text {mo }}$ B. ${ }^{\circ}$ de Cnimbra D. $^{\mathrm{a}}$ a sua carroca, e com eff..$^{\circ}$ nella o conduzio p: a sua cid. ${ }^{\circ}$, e Palacio Episcopal. e nelle se dilatou o dia 16, e 17 de Agosto. Houve repiques, e de noite luminarias em boa parte 


\section{D.: Miguel da Anunciaçâo}

da Cid. ${ }^{\circ}$, e em todas as cazas dos R.R. Conegos, e Ministros Eccleziasticos, e Seculares. No dia 17 de Agosto pela manhã foi o Ex. ${ }^{m}$. B. ${ }^{\circ}$ Conde ouvir Missa ao Exemplar Conservatorio com o titulo dos SS. ${ }^{\text {mo }}$ Coraçoens de Jesus, e Maria, ahi deo a benção áquella devota Communid. ${ }^{\circ}$, aonde foi recebido com Te Deum Laudamus. Pouco depois na mesma manhã Conduzido o Ex. ${ }^{\mathrm{mo}}$ B. ${ }^{\circ}$ de Leiria na sua Carroça ao Ex. ${ }^{\mathrm{mo}}$ B. ${ }^{\circ}$ de Coimbra athe a sua Cathedral, aonde aquelle Prelado cheio das mais christans politicas, e urbanid. ${ }^{\circ}$ fez receber pelo seo Cabido illustre ao Ex. ${ }^{\text {mo }}$ de Coimbra, como o proprio Prelado, fundando o excesso do seo resp. ${ }^{\circ}$ não só no merecim.to do m. $^{\text {mo }}$ Ex. ${ }^{\text {mo }}$ de Coimbra, mas tão bem em q' este Prelado o foi daquella Dioceze juntam.t t $^{\circ}$ com Coimbra. No dia 18 pela manhãa depois de ouvir Missa no Oratorio do Ex. ${ }^{\text {mo }}$ B..$^{\circ}$ de Leiria proseguio a sua jornada p $^{a}$ o Louriçal. Acompanhou-o Ex. ${ }^{\text {mo }}$ Prelado de Leiria, e conduzio na sua $m$. $^{\text {ma }}$ carruagem ao Ex. ${ }^{\text {mo }}$ de Coimbra athe huma Legoa distante de Leiria. De hum, e de outro estado foi celebre o acompanham.t $t^{\circ}$. Despedirão-se os dois Prelados com demonstraçoens de saude, e de resp. ${ }^{\circ}$, que parece enlaçarão p. ${ }^{a}$ sempre aquelles dois sagrados animos com vincolo de eterna amizade. Recolheo-se o Ex. ${ }^{\text {mo }}$ de Coimbra á sua Carruagem, e proseguio a sua jornada athe a Cap. ${ }^{a}$ da Snr. ${ }^{a}$ da Guia, q' dista huma legoa do Louriçal. Huma antes que chegasse a este sitio vierão festejar, e receber a S. Ex. ${ }^{\text {a }}$ m.tas pessoas do Louriçal de Cavalaria, e m.t t $^{\text {os }}$ meninos com bandeirinhas com inscripçoens, q' dizião - Viva o Snr.' B..$^{\circ}$ Conde - outros com canas verdes em sinal de triunfo. Esperavão junto á Cap. ${ }^{a}$ da Guia as Ordenanças em fileiras, pelas quais passou S. Ex. ${ }^{a}$, recebido com todas as demonstraçoens, e honras militares. Apeou-se o Prelado p. ${ }^{a}$ fazer oração na Capella da Guia, e recolhido q' foi novam.t $t^{\circ}$ á sua Carruagem p. ${ }^{a}$ prosseguir o cam. ${ }^{\circ}$, salvarão as Ordenanças, e soou m.tas vezes hum viva triunfal. Ao entrar no Louriçal foi S. Ex. ${ }^{a}$ recebido das Ordenanças, e com hum aplauzo universal daquelle Povo, que vive á sombra de hum Santuario do maior exemplo, q tem S. Ex. ${ }^{a}$ no seo Bispado. Encaminhou S. Ex. ${ }^{a}$ os passos p. a Igreja do Convento das Religiozas: o melhor da Muzica de Coimbra esperava na Igreja o seo Prelado, ao entrar lhe contarão as palavras do livro do Eccleziastico, q' em a dizer: Eiz aqui o grande Sacerdote, q' nos seos dias agradou a D.s, e se achou justo. Dita, e cantada esta misterioza, e bem aplicada antiphona, se entoou o himno Te Deum em acção de graças a D. N. Snr. pela restituição de S. Ex. ${ }^{a}$ ao seo Bispado, e a este Santuario, que teve maior parte no jubilo, assim como a teve na pena da sua transportação. Recolheo-se á sua Hospedaria do Convento,

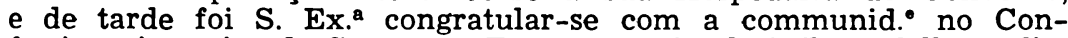
fessionario maior do Convento. Esta terra, q' pelo influxo delle se distingue $m . t^{\circ}$ no amor, e resp..$^{\circ}$ deste Prelado, se esmerou nos maiores obzequios, e mais sinceros, q' se lhe fizerão em toda a parte. Alem das $\mathrm{m} . \mathrm{t}^{\mathrm{as}}$, e vistozas luminarias, repiques, e vivas, preparou hum carro triunfal, no qual alem de outras figuras, que expressavão o seo jubilo, com romances serios, e laudatorios, hião duas, q' reprezentavão a Coimbra, e Louriçal, as quais em hum dialogo poetico contendião suavem. $t^{\circ}$ sobre a materia da sua exultação: hia a Carroça adornada de louros, e Palmas elevadas, e debaixo das rodas giravão m.to ramos de carvalho, q' erão abatidos, e trilhados com o movim.to das rodas, quando se revolvião. Cercava m.ta gente com luzes o carro, e na pauza das vozes poeticas soavão m.tos Instrumentos com harmonia. Parou em diversos sitios a carroça, repetindo gostozam. $t^{\circ}$ o Dialogo, e romances, q' continhão toda a razão do contentam. t $^{\circ}$ e acabava tudo com hum viva universal, e hum brado de triunfo, e isto em todos os 3 dias seguintes. No dia 19 pela manhã foi S. Ex. a recebido na Igreja do Con- 


\section{O Marqués de Pombal}

vento das Religiozas com as ceremonias sagradas do recebim.t to $^{\circ}$ Prelados, com osculo de cruz, thuribulo, incenso, e palio. Entoou o Presbitero recipiente o Te Deum, q' prosseguio a Muzica de Coimbra suavem. $t^{\circ}$ athe a sua concluzão. $O$ Presbitero, que fazia a figura de Confessor do Convento, disse revestido de pluvial a Oração costumada em tal cazo. Subio então S. Ex. ao seo Trono Pontifical, que lhe estava preparado, e cantou o coro das religiozas as antiphonas do SS. ${ }^{\mathrm{mo}}$ Sacram. to $^{\circ}$ Titular da Caza, e dos seos S.t ${ }^{\circ}$ Patriarchas, e S. Ex. ${ }^{2}$ dice as Oraçoens respectivas, e concluio com a Benção sobre todos. Seguio-se a Missa, q' celebrou, como costuma todos os dias, o Ex. ${ }^{\text {mo }}$ Prelado, assistido de dois Conegos, hum de Leiria, q' desde esta cid. 0 acompanhou the Coimbra, e outro da sua Sé, que obteve em premio dos trabalhos da sua injusta prizão o Benef. ${ }^{\circ}$ da inteira Prebenda, q' se achava vago no tempo da sua soltura, e competia pela alternativa a S. Ex." a sua Colação. Outro Conego assim mesmo provido, e q' correo com S. Ex. a m. ${ }^{\text {ma }}$ sorte, acompanhava, e honrava o Ministerio do Mestre das Ceremonias. Acabada a Missa, e dadas as graças, foi S. Ex." ouvir as Religiozas ao seo Confessionario, q' he o lugar, aonde este Prelado costuma ouvir esta Santa Communidade. Encherão-se estes Espiritos de hua alegria santa, e innocente, e enxugou $D^{8}$. as lagrimas de oito annos convertendo-lhe o pranto em alegria, e cercando de huma innocente as Venturozas almas deste Santuario, q' vião a restituição do seo Prelado, e Confessor restituida toda a sua gloria, e satisfeita inteiram.t a profecia da Serva de D. Sor M.a Joanna Religioza q' foi deste Convento, que vaticinou todo este triunfo com misteriozas expressoens, como consta de huma Carta escripta de sua letra ao seo Confessor antes do anno de 1754, em q' faleceo, e se guarda no Archivo deste convento. Descançou S. Ex. " das molestias da jornada neste Hospicio do Louriçal athe o dia 21 de Agosto. Neste depois de celebrar S. Ex. ${ }^{a}$ o S.to sacrificio da Missa na Igr.. ${ }^{\circ}$ do Convento, continuou a sua jornada p.a Coimbra, e p.a dar lugar ao recebim.to solemnissimo, que lhe queria fazer o Illustre Cabido, e Cid. ${ }^{\circ}$ de Coimbra, foi huma breve digressão por Pereira, p.a esperar na sua Quinta de S. Martinho os obzequios do Cabido, e Cid.` na sua ultima conducção, e acompanham. t $^{\circ}$ Duas legoas longe do Louriçal na entrada da Ponte de Soure esperavão formadas as Ordenanças, q' receberão, e cortejarão com as suas politicas militares, e salvas, ao seo restituido Prelado, acompanhando os repiques e vivas do Povo os estrondos Marciais. Como S. Ex." destinava seguir a estrada p." Pereira, não entrou em Soire, desviou-se p.a a estrada de V.a Nova de Ansos. De todas as Povoações q' estão neste Cam. ${ }^{\circ}$, sahio o Clero, e Povo, e em alguma parte forão tantas as lagrimas, e suspiros de gosto, q parecia degeneravão no excesso de sentir ao seo Prelado, quando removido. Corrião mulheres, e homens pa o ver, e chegarão a impedir o progresso do caminho. S. Ex." os despedia com a benção, e liberalid.' pela tarde, q' serião duas horas, chegou S. Ex." a Pereira, e foi recebido na Igreja do Conservatorio das Urselinas com Te Deum cantado com bem acorde muzica, e concluirão com o verso, q' vem proprio ao cazo: Bemdito o $q^{\prime}$ vem em nome do Snr. Gloria nas alturas - Hospedou D. Nuno Antonio Alvares Botelho a S. Ex. ${ }^{a}$, e depois de dar S. Ex. a benção a este Illustre Conservatorio, prosseguio o caminho, e viagem de tarde athe a Quinta Episcopal de S. Martinho.

Não pode explicar-se o excessivo jubilo, com q' os Povos dos lugares vezinhos receberão ao seo restituido Pastor; era noite, e a multidão de luminarias não só nas cazas, mas pelas ruas fazião hum ramo luminozo do dia; soavão continuos vivas; e via-se neste universal contentam. t $^{\circ}$ a sua sinceridade, e a sua cauza. Recebião alegres a hum 


\section{Miguel da Anunciação}

Prelado não indulgente aos vicios, não dissimulador, mas severo, zelozo, vigilante, que já mais deixava viver em paz os vicios emq.to se não emendavão. Eiz aqui o Prelado dezejado destas gentes, e a sua Expectação, que não veio a introduzir a paz no meio das maldades, mas a espada e a justiça, com piedade sim, porque ella não queria da correcção mais utilidade, que a emenda dos culpados; $m .^{\text {as }}$ vezes sahia á custa da sua profuza carid. a despeza, e pena dos mesmos criminozos. Em hum lugar vezinho á sua Q.t vezitou S. Ex. a hum honrado Eccleziastico, e Conego seo, q' estava enfermo, não se esquecendo de favorecer, e consolar assim ao enfermo, e preferindo esta obra de Caridade a todos os resp. ${ }^{\circ}$ do seo Caracter, e do seo Sangue. Chegou finadm.t ${ }^{\circ}$ á sua Q.t t $^{\mathrm{a}}$ Eiscopal chamada de S. Mart. ${ }^{\circ}$, aonde depois de vizitar a sua Cap. ${ }^{a}$ dedicada ao SS. ${ }^{m o}$ Coração de Jesus, e depois de agradecer a D. N. Snr. o benef. ${ }^{\circ}$ da sua restituição ,se recolheo a passar a noite. No dia seg.t . $^{\circ}$ pela manhã foi vezitado S. Ex. ${ }^{a}$ do milhor de Coimbra, e da Universid. desde o seo actual V. R.or D. Carlos M.a de Figueiredo Pimentel. Passado o jantar pelas 3 horas principiou a chegar a comitiva, $q$ havia de o acompanhar athe Coimbra, e athe a sua Cathedral, aonde se dirgirão os passos de S. Ex.a, antes de se recolher ao seo Paço Episcopal. Honravão a comitiva Lentes da Universid.', Collegiais de ambos os Collegios, Conegos da Se de Coimbra, Prelados das Religioens, e outras m.tas pessoas distinctas pelo seo merecimento e officio, como Menistros, e Cavalheiros. Constava a Illustre multidão de 47 Carruagens, além da cavalgata.

Os Serenissimos Snr.`s Infantes D. Antonio, e D. Joze, q' ainda estavão em Coimbra, e no Real Mosteirao de S.ta Cruz, offerecerão, e enviarão p. ${ }^{a}$ conduzir a S. Ex. huma Berlinda tirada de seis bestas. Estes Snr."s se distinguirão excessivam.t.$^{\circ}$ em tudo o q' era obzequio a respeito de S. Ex. ${ }^{a}$ nesta sua Restituição. Chegou a Berlinda a S. Martinho, poz-se em ordem a Comitiva, S. Ex.a, q' só estava despido dos habitos viatorios, e revestido de roquete, entrou com o seo Pagem de cauda na Carroça destinada. Hião adiante todos os q' o vierão buscar desde Coimbra, e seguião a Cárroça de S. Ex. " todos os de sua Familia, q' nunca foi numeroza. Antes de entrar na ponte esperava o seo Prelado huma grande multidão de meninos talvez daquelles, q o mesmo Prelado vestia, e ensinava a Doutrina Christãa. Estava esta multidão de innocentes vestida festiva, e triunfalm.t ${ }^{\circ}$; levavão nas tarjas varias Inscripçoens, especialm.t t $^{\circ}$ como mais proprio o do Psalmo 8, que diz fielm.t ${ }^{\circ}$ na nossa lingoa $=S n r$. da boa boca dos meninos, $e$ dos $q^{\prime}$ ainda pendem do peito, aprefeiçoastes o louvor p. $^{a}$ confuzão dos vossos inimigos, p. $^{a}$ destruir o adversario, $e$ o Vingador $=$. Era copiozissimo o numero destes innocentes pregoeiros do triunfo, que não contentes com este aplauzo, com tambores, e bandeiras acompanhavão a carroça do Ex. ${ }^{\text {mo }}$ Prelado. Na Ponte do innumeravel povo, e ainda gente mui distincta de hum, e de outro sexo, esperavão a S. Ex.a as Companhias das Ordenanças bem formadas, q' o receberão com as costumadas cortezias da milicia, e derão as salvas de carga militar. Tinha ordenado o Senado da Camera, q' a cid. ${ }^{\circ}$ e seos moradores tivessem o cuid. ${ }^{\circ}$ de ter preparadas as ruas, armadas as janellas, e promptas as luminarias em trez noites successivas á sua entrada. Como são bem cheias de honra, e respeito, as palavras, com q' o m. ${ }^{\text {mo }}$ Senado da Camera recomendou aos seos moradores as demonstraçoens do seo ubilo por huma acção tão nova na restituição do seo Prelado, eu dou a ler huma fiel copia do $\mathrm{m} .{ }^{\mathrm{mo}}$ avizo, e he o seguinte: 


\section{O Marquês de Pombal}

\section{«Copia»}

O Doutor Juiz de Fóra, Vereadores, Procurador Geral do Senado da Camera desta cid..$^{\circ}$ de Coimbra, e todo o seo termo por S. Mag. ${ }^{\bullet}$ Fidelissima, q' D. ${ }^{\circ}$ g.d $d^{\bullet}$ V.a

Fazem saber, que sendo das santas, e saudaveis intençoens de S. Mag. ${ }^{\circ}$ Fidelissima, e havendo tantos e tão justificados motivos p. ${ }^{a}$ se festejar, e obzequiar a vinda do Ex. ${ }^{\text {mo }}$ e R. ${ }^{\text {mo }}$ Snr. D. Miguel B. ${ }^{\circ}$ Conde a esta cidad. : Determinou o m. ${ }^{\text {mo }}$ Senado, que todos os moradores della, e seo termo, fação, e executem todas as demonstraçoens de alegria, e festivid. ${ }^{\circ}$ no dia da $\mathrm{d}^{\mathrm{a}}{ }^{\mathrm{e}}$ entrada do referido, e virtuozo Prelado, q' hade ser na tarde do dia de sexta fr. ${ }^{a} 22$ do prezente mez, limpando as ruas, armando as janellas, pondo luminarias na noite do d. ${ }^{\circ}$ dia, e nas duas seguintes, entoando continuos clamores de vivas em triunfo de tão admiraveis virtudes, que resplandecem em hum tão bom, e S.to Pastor, tudo pouco $\mathrm{p}^{\mathrm{a}}$ se lhe restituir o jugo, e obediencia, q' lhe devem huns tão fieis Vassallos de Sua Mag. ${ }^{\circ}$, e humas tão innocentes Ovelhas. $\mathbf{E}$ p. $^{\mathbf{a}} \mathbf{q}$ assim se execute, se mandarão fixar estes pelo Escrivão do Senado, em Coimbra 21 de Agosto de 1777 etc.

A Universid. ${ }^{\circ}$ depois de fazer hum Congresso, ou como chamão Claustro, dos seos Lentes sobre receber, repicar, e aplaudir com luminarias o Prelado, que foi seo Cancellario, e m.to antes seo Lente na Faculdade de Canones, depois deste sabio ajuntam. t $^{\circ}$ escrupolizou fazer demonstração exterior igual áquella, com q' receberia alguma Pessoa Real, sem ter precedido p. ${ }^{a}$ isto avizo superior. Porem a mesma Universid..$^{\circ}$ mandou dois dos seos $\mathbf{M}^{\text {es }}$ expressam.te nomeados, . $^{\mathbf{a}} \mathbf{q}^{\prime}$ acompanhassem a S. Ex. a athe a sua Cathedral. No Arco, que chamão de Almedina, estava huma tarja, que dizia $=$ ' Bemdito, o q vem em nome do Snr. - Caminhou a comitiva athe o Terreiro da Sé, que hoje he Mizericordia, e dahi athe o Terreiro da Igreja do Colegio das Artes, que hoje he Cathedral. Neste Terreiro estava huma Companhia de Auxiliares bem formados, e innumeravel concurso de povo p. ${ }^{\mathrm{a}}$ vir apear aos degraos do Colegio, é hoje Sé, o seo restituido Prelado. Esperava no portico o Corpo Illustre do Cabido, Conegos, e mais Menistros a S. Ex. aonde foi recebido com as ceremonias costumadas em tais cazos. Foi conduzido p. ${ }^{a}$ o Coro e capella mor da grande Igreja, que hoje serve de Cathedral: o concurso do povo não deixava ver mais, que o Palio debaixo do qual hia o Prelado. Revestido q' foi das vestes, e insignias Pontificais, e Pastorais no seo throno, foi conduzido da sua Cap. ao Altar mor o SS ${ }^{m o}$ Sacram. to $^{\circ}$ e exposto com o preciozo aparato de throno, e luzes, adoraçoens, e incensos. A Muzica de belas vozes, e Instrumentos fazia huma consonancia. Logo entoado o himno Te Deum, em acção de graças pelos beneficios feitos a esta Cathedral, e á Igreja pela restituição deste Prelado, proseguio a Muzica o mesmo himno, e dice $\mathrm{S} \mathrm{Ex}^{\mathrm{a}}$ as Oraçoens respectivas. Cantou-se o Tantum ergo em adoração do SS.mo, e com o mesmo deo S. Ex. ${ }^{a}$ a benção ao seo Cabido, e Coro. Recolhido novam.t ${ }^{\circ}$ o SS.mo na sua Capella, se recolheo S. Ex. ${ }^{a}$ ao seo Palacio Episcopal. Nelle esperavão o Prelado suas Altezas Seren. ${ }^{\text {mas }}$, dignando-se elles mesmos sem se esquecerem de q. $^{\mathrm{m}}$ são, receber, e vir esperar athe a entrada da prim. ${ }^{a}$ Sala a S. Ex. ${ }^{a}$, honrando-o com tão humildes respeitos, como se elles fossem seos subditos; influira piedade nestes obzequios, e o amor, com q' estimavão a restituição de hum Prelado, q o fora do Mosteiro de S.t ${ }^{\text {a }}$ Cruz, aonde SS. Altezas seren. ${ }^{\text {ma }}$ viverão tantos annos, como Conegos Regulares athe nos habitos. Foi entre estes Senhores, e S. Ex. a congratudação mutua mais parecida á cauza, e sincero o jubilo reciproco. Estes seren. ${ }^{\text {mos }}$ Snr. ${ }^{*}$, que forão 


\section{Miguel da Anunciação}

sempre as dilicias do Reino pelo seo merecimento, virtudes, e afabilid." Summa, agora ainda se fazem mais amaveis depois da sua restituição. A Corte os espera com huma bem justa saudade, e estes seren. ${ }^{\text {mos }}$ Snr $^{\text {es }}$ atrahirão ainda mais os coraçoens de todos pela benignid." dos soos, e farão huma parte respectiva da nossa felicid. ${ }^{\circ}$ completa com a sua dezejada restituição á Corte, e formarão huma agradavel figura ao lado dos nossos amados soberanos, que os amão, e são destes Sons. ${ }^{.} \mathrm{s}$ fiel, e sinceram. $\mathrm{t}^{\circ}$ respeitados.

Recolheo-se S. Ex. ${ }^{\mathrm{a}}$ ao seo quarto acompanhado por Suas Altezas. Esquecidos do seo sangue, ou mui lembrados delle, p. ${ }^{a}$ honrar as Veneraveis Cans de hum tão Santo Prelado, julgarião, e bem, que tudo era pouco p. a exaltação da sua honra, e virtude. Aceitou S. Ex. ${ }^{a}$ este estraordinario Cortejo de SS. Altezas seren. ${ }^{\mathrm{ma}} \mathrm{s}$, porq. só p. ${ }^{\mathrm{a}}$ isto prevaleceo a sua authorid." p. a q' já mais cedesse aos humildes protestos de S. Ex. ${ }^{a}$ Despedirão-se SS. Altezas Seren. ${ }^{\text {mas }}$, e em huma Carruagem ligeira se retirarão ao Most. ${ }^{\circ}$ de S.t a $^{\text {a }}$ Cruz, aonde estão inteirinam.t ${ }^{\circ}$ hospedados. Apenas S. Ex. ${ }^{a}$ se recolheo ao seo quarto veio logo o $\mathrm{Ca}-$ bido, Conegos, e todo o Corpo Eccleziastico da Sé em communid. ${ }^{\circ}$ debaixo de cruz, veio desde a Sé the o Paço Episcopal cantando o canto de Zacarias = Bemdito o Snr.' Deos de Israel, q'vezitou, e fez a redempção do seo Povo = Foi recebida com admiração, e aplauzo, esta não esperada vezita, mas bem merecida de hum Prelado, que era viva forma desta, e melhor porção do seo rebanho. S. Ex. ${ }^{a}$ agradeceo com as mais verdadeiras demonstraçoens da sua estimação, e jubilo, este excesso de contentam. $t^{\circ}$ da sua Cathedral, $q^{\prime}$ novam. $t^{\circ}$ o move, como Espoza sua, da qual hum divorcio injusto o tinha separado, ainda q' nunca já mais quanto ao Vinculo. Deixaroã SS. Altezas seren. ${ }^{\text {mas }}$ o seo Coche, em q' o Prelado fora conduzido, com ordem, p. ${ }^{2} q^{\prime}$ servisse a S. Ex.., levando-o na m.ma tarde p. ${ }^{a}$ o Mostr. ${ }^{\circ}$ de S.ta Cruz - Com eff. ${ }^{\circ}$ S. Ex..$^{a}$ se recolheo a passar essa noite nelle, obrigando-se forte, e suavem.t t $^{\circ}$ de dois motivos; o particular de beijar as mãos de SS. Altezas seren. ${ }^{\text {mas }}$ em sua Caza em agradecim.t $t^{\circ}$ de tantas honras recebidas, e em signal de q' S. Ex. dezejava prevenir a antecipada honra com q' SS. Altezas Seren. ${ }^{\text {mas }}$ se anteciparão a todo o obzequio de S. Ex.a; a couza menos principal erao amor com q' este Prelado estima o viver na sua communid..$^{\circ}$ mostrar-se continuam.t t $^{\circ}$ athe nos habitos, hum dos mais amantes filhos della. Neste Mostr. ${ }^{\circ}$ e aos pés de suas Altezas Seren. $^{\text {mas }}$ forão novos jubilos, e contentamentos huma cauza tão interessante ao bem commum.

Recolheo-se S. Ex. ao seo Paço no dia sabado 23 de Agosto aonde recebeo continuos parabens dos seos subd. ${ }^{\circ}$. As Colegiadas da cidade imitarão o ceremonial dos illustre Cabido, buscando todos a S. Ex. em communid. com cruz, e ordem. No Domingo 24 de Agosto houve hum festejo de fogo, e luzes no Seminario, a principal obra, que foi desde a prim. ${ }^{\text {a }}$ pedra das despezas de S. Ex. ${ }^{\mathrm{a}}$, na qual gastou muitos centos de mil cruzados, sem faltar já mais aos copiozos dispendios das suas mercearias, e esmolas.

No Domingo, que se contarão 31 de Agosto fizerão os Muzicos da Capella Episcopal, e Cathedral huma solemnid.' piissima, e pompoza no Real Mosteiro de S.ta Cruz, e oração de graças a N. Snr. a pela restituição do seo Prelado. Dice huma elegante Oração em agradecim.to hum Conego Regular bem conhecido pelas suas letras, e virtudes, D. Antonio da Madre de D. Theologo da Universid.' da cid. ${ }^{\bullet}$ de Coimbra. Honrarão a festivid. ${ }^{\circ}$ com a sua assistencia publica desde a sua Tribuna os Serenissimos Senhores Infantes. Como objecto, ou sugeito da Solemnidade, estava prezente o Ex. ${ }^{\text {mo }}$ B. ${ }^{\circ}$ Conde; e SS. Altezas 


\section{O Marquês de Pombal}

seren. ${ }^{\text {mas }}$ se dignarão acompanhar no fim da Acção o mesmo Prelado ao seo religiozo Cubiculo com demonstraçoens tão excessivas, que só cabem nos seos reais animos, e pouco na minha rude pena.

Fim

\section{Adição}

Entrou S. Ex. ao Arco da Portage, e deste sito athe a Cathedral estavão as Ruas espadanadas, e as janellas das cazas ornadas de cortinas, e cobertores de Damasco, e outras Tapeçarias de varias cores: donde aquellas Pessoas, cujo sexo lhes não permettia vir á Rua unir os seuos vivas aos do Povo, explicavão a sua alegria derramando hum diluvio de flores sobre o coche de S. Ex..

\section{Outra}

Em Taveiro estava grande parte do Cabido, e outras Pessoas Eccleziasticas, e Seculares, q' da Cid.' vierão esperar a Sua Ex..

\section{XI — O CÓNEGO LUfS DE MELO}

LUIZ DE MELLO antural de Ancião do Bispado de Coimbra foi nomeado pelo Senhor Bispo Conde p. ${ }^{a}$ Ministro da Sua Meza Ecleziastica por mediação do Reverendo Doutor Manoel Rodrigues Teixeira Tezoureiro mor, e Provizor do Bispado. Tendo servido alguns annos, succedeo vagar em mez da apprezentação de Ordinário a Porcionaria da Cathedral a que esta annexo o Curato da Freguezia; e ainda que na dita Meza Eccleziastica havia Ministros mais antigos, e de muito merecimento; foi preferido o dito Luiz de Mello ao dito Beneficio pelo Senhor Bispo Conde em contemplação a ser elle m.t ${ }^{\circ}$ pobre, e ás obrigaçōens de sustentar a seu Pay ja velho, a trez Irmaãs, sendo huma dellas cega, e alguns Irmãos, como reprezentou a S. Ex." o sobredito Reverendo Doutor Provizor. Assim q obteve aquelle Beneficio, q augmentando as suas forças, diminio a sua dependencia, não por tanto cuid..$^{\circ}$ em moderar o seu genio; e ainda que tinha devido á honra, e á prudencia do Prelado a sua conservação, que parecese não compadecia com a boa ordem dos negocios Eccleziasticos, cingindose o mesmo Prelado ao Cuidado de occorrer ás suas intrigas; elle perdeo aquelle emprego pelos mesmos meios, q projectou p. ${ }^{\mathrm{a}}$ o exercer com mais liberdade; pois que tomando a rezolução de despedir-se na esperança de $q$ lhe não seria aceita a escuza, mas antes se faria alguã ventagem, por se considerar o Ministro mais habil, e necessario; muito contra a sua Capectação se vio distituhido, aceitando o Prelado com m.ta prudencia os seus affectados pretextos. A os estimulos do seo genio acrescêram os desta expulsa, ainda que na especie de voluntaria; e por satısfação a elles, influio o dito Luiz de Mello ao Prior de São Christóvão p. ${ }^{a}$ que désse conta ao Ministerio da Pastoral, q mandára publicar o dito Senhor Bispo Conde, affectando os escrupulos, q tinha na publicação; e Logo que esta conta surtio o effeito, que elle se havia proposto, partio p.a a Côrte tanto afim de fazer atear o incendio, a que tinha dado materia, que alem do que disse de viva voz contra o Prelado seu Bemfeitor, e contra o dito Doutor Provizor, a cuja mediação 


\section{Miguel da Anunciação}

devêra tanto, offereceo ao Marquez de Pombal de sua mesma Letra hum papel, do qual se formáram os Interrogatorios da devaça, e de que foi fidelissimamente extrahida a copia seguinte.

\section{Noticia \\ De alguns factos respeitantes ao Bispo de Coimbra}

Este Prelado entrou com fama de Santidade, mas o tempo foi dezenganando a gente da sua Hypocrezia. Logo nos principios do seu governo não deixou de se reparar na sua soberba. Mandava avizo a todos os Capitães mores, q quando elle entrasse nas terras do Bispado, estivessem com toda a Ordenança dando-lhe descargas em quanto elle passava: e depois fallava quando $\mathrm{m} . \mathrm{t}^{\circ}$ de pé, e sobpezado aos Capitães mores, sem lhes dar a mais leve demonstração de agradecim.to por aquelle obzequio, e por isso deixaram de lho fazer.

Aos Clerigos regularm.t $t^{\circ}$ falla imperiozam.t', deixando-os estar de joelhos todo o tempo; a alguns de pé por elles se levantarem; a poucos de assento, e a esses ou por alguma depend. ${ }^{\mathrm{a}}$ quando a tem, ou por ver q não soffrerão por outro modo.

$\mathrm{Na}$ ambição de dinh. ${ }^{\circ}$ he insaciável: o pretexto de o extorquir he o Seminario, que certam. $t^{\circ}$ fêz á custa do Bispado, e ainda lhe cresceo m.t dinhr. $^{\circ}$. Mandou q se não despachasse rol algum dos Confessados, sem o Parocho mandar, ou sua, ou pedida na freg. a esmola de 6400 , e depois se abateo 4800 , e assim se pratica. Grd. ${ }^{\circ}$ colheita em hum Bispado tão dilatado, ha mais de vinte ann. a esta p.t'.

Ao todos os Clerigos do Bispado escreveo a cada hum huã carta de proprio punho pedindo-lhe esmola. Em tanta quantid. de Clerigos, tambem fês grd. ${ }^{\circ}$ colheita de dinhr. ${ }^{\circ}$. Todos lhe deram por conciliarem o seu agrado, e não cahirem na sua disgraça.

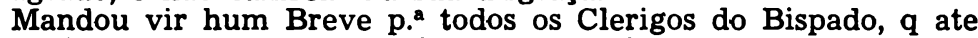
então rezávam pela Ordem geral, rezarem pela folhinha dos Frades Cruzios dos seos sanctos Conegos Regulares. E com pretexto de não haver cadernos dos ditos Santos, senão som.t t $^{\circ}$ os particulares do Mostr. ${ }^{\circ}$ de Sancta Cruz, os mandou imprimir p. todo o Bispado, e os vende aos Clerigos por terceiras pessoas a 960 , e $800 \mathrm{r}^{3}$ cada hum, obrigando a q cada Clerigo tenha seo caderno, p. ${ }^{a}$ o q em vizita lhe manda pôr na primeira folha o nome do Clerigo, afim de não servir p.a outro, e são obrigados a apprezentarem cada qual o seu na vizita: tambem não foi pouco copioza esta colheita.

Outra ideia de tirar dinheiro foi a das pedras de ára: Mandou fazer infinitas de pedra de Ançaã facil de lavrar com m.to pouca despeza, e as vende p. o Bispado a 800, e 600 r.8; e p." que ninguem fique,

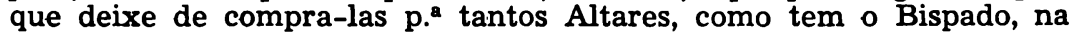
maior p.t॰ delles por si, e seus vizitadores suspendeo as que havia sem cauza p." as suspender por serem boas, e alguãs ainda melhores, do $q$ as que elle vende, e outras as quebram em acto de vizita, e assim não ha remedio senão comprar.

$\mathrm{Na}$ maior p.t ${ }^{\bullet}$ do anno anda em vizita, hospedando-se em caza dos Parochos, $q$ nisto fazem involuntarios excessiva despeza: e se algum se escua da hospedagem, e com grandeza, logo he mal visto, e culpado na vizita.

Trouxe comsigo na vizita varios annos ao seo Dilecto Condescend.t ${ }^{\circ}$ Adulador Manoel Roiz Teixeira, hoje Provizor, e Tezour. ${ }^{\circ}$ mór na Sé, em tempo q era vig..$^{\circ}$ geral, e tiráram infinito dinh. ${ }^{\circ} \mathrm{Em}$ Aveiro nas Cazas aonde o dito Provizor vizitador se hospedava, the pozeram 


\section{O Marquês de Pombal}

duas grandes tarjas de papel bem pegado com asa de livreiro, e em cada huã dellas esculpido hum grande L que queria dizer Ladrão.

Na mesma Cid. de Aveiro a outro seo vizitador Theotonio Valerio espancáram hum creádo, e que levasse noticias ao Amo, que lhe fariam o mesmo se não se retirasse, e houve por sua saude o retirar-se.

Nenhum conceito ha de similh.t? vizitas, e todos as abominam; porque aquillo he huma finta geral, e o que mais he as infamias, $q$ deixam aonde nunca houve infamia. $O$ ponto he fazer muitas multas, e tirar dinhr..$^{\circ}$; Sensum annuum exigunt á Concubinariis, et salvum conductum praestant, ut in suo peccato permaneant; contou ja Garcia da Beneficüs: mas aqui ha mais, suppoemse escandalo aonde o não ha, culpando sem discernimento, sem prudencia, e sem aquellas circunst. ${ }^{\text {a }}$ que o Dir.t ${ }^{\circ}$ requer: $O$ estillo he culpar sempre os mais pobres, porq não rezistem, nem aggrávam p. a a Corôa; págam as multas promptam.t', e assim se vai enchendo o peculio.

Hum dia na Sé me chamou á p.t ${ }^{\circ} \mathrm{o}$ dito actual Provizor em tempo eu era Dez.or da Meza, e me disse como por grande fortuna que o Prelado me tinha feito vizitador do Arcediago de Vouga, $q$ he o melhor, e $\mathrm{q}$ fosse eu a sua caza p. ${ }^{\mathrm{a}}$ me dar da p.t $\mathrm{t}^{\circ}$ do Bispo as instrucçoens necessar. ${ }^{\text {as }}$. Fui a sua Caza, entrou a instruir-me dizendo, que ja sabia, que os vizitadores se hospedavam em caza dos Parochos, e q assim nada gastava. Que podia fazer boa conveniencia, porq hum vizitador podia m. $\mathrm{t}^{\circ}$. Mas que cautellozam. $\mathrm{t}^{\circ}$ havia eu de observar aquelles Parochos, e Clerigos, que eram misticos, e capazes de fialm. $\mathrm{t}^{\circ} \mathrm{da}-$ rem conta de tudo ao Bispo, ainda de mais occulto pensam.to dos freg.es. Porque o Prelado era Pay, e devia saber os defeitos dos seos filhos; e q era Medico, e devia saber os achaques dos seos enfermos; ainda os mais escondidos, e de maior segredo, pois esses por menor conhecidos ainda eram mais perigozos. Logo me não cheirou bem esta primr. ${ }^{a}$ instruç̧ão, porq me parece se encaminhava áquella peste sigillistica, $\mathrm{q}$ tanto tem inficionado aquelle Bispado. Continuou o Instruente entre outras couzas dizendo, que eu havia de culpar, e condenar em cinco tostões a todas as mulheres dos Campos de Coimbra, Aveiro, Salreu etc. q achasse escamizavam milho na Companhia de homens; como tambem a todas aquellas, $q$ andassem ou tivessem andado a sachar milho em manteo, e sem saia, e Capotinho. Ouvindo eu estas couzas não fiquei contente ,disse-lhe q tudo se faria em bem, e que fallariamos mais devagar: Vim p. minha caza; considerei nas instrucções; assentei q não podia dizitar ligado a simillantes preceitos, quando som.t $t^{\circ}$ a hospedagem em caza dos Parochos me era prohibida pela mesma constituição do Bispado; quanto mais pela desconfiança, com q fiquei de me quererem meter na dita peste sigillística, e precizar-me a fazer a huãs pobres mulheres culpas infinitas, extorquindo-lhe dinhr..$^{\circ}$ e deixando-as infamadas. $\mathbf{E}$ por que se assim o não observasse certam.t t $^{\circ}$ Bispo, e se o Provizor se desgostariam comigo; no dia seg.t t $^{\circ}$ fui agradecer ao Bispo, e me escuzei com o pretexto de doente, e q em minha caza despacharia os feitos. Foi outro, e trouxe huã boa colheita das mulheres dos mantéos.

Tendo por certo, e assim se julga q por conta da dita peste sigillistica tem tirado a licença de confessar aos melhores confessores, e ainda as Religiōes, dando-a a rarissimos, e estes idiotas sem instrucção, nem capacid. ${ }^{\circ}$ Por esta falta de confessores se acha o Bispado em bastante consternação: e por outra parte recea a g.t $t^{\circ}$ confessar-se a esses raros confessores, que poem, porq vê o seo idiotismo, e aptidão p. . $^{\mathrm{a}}$ irem revelar tudo ao Bispo: elle com eff.to não fazendo cazo dos Sacerdotes doutos, e prudentes, pelo contrario faz cazo de alguns Clerigozinhos 


\section{Miguel da Anunciação}

ignorantissimos; a estes he q dá licença de confessar, e por todo o Bispado os tem, com Malsins, q de tudo lhe dão conta.

A este respeito duas couzas mais notei em confissão, q posso contar sem entrar na conta dos Revelantes sigillistas. A primeira he que ouvindo de confissão a hum, ou huma penit.• por largo tempo esteve confessando peccados alheios, sem dizer nenhum seo, até que reprehendi, que não confessasse peccados de outrem, mas só os seus; porem continuou como dantes na mesma narração das vidas alheas, e descubrir as faltas do proximo, ao mesmo tempo que dizia, q p. nenhum desses peccados alheios concorria; e dizendo-lhe, pois p. ${ }^{\mathrm{a}}$ que confessa peccados alheios se p. ${ }^{a}$ elles não concorre? Respondeo que na sua terra tinha hum P.e Espiritual, a quem se costumava confessar, o qual lhe tinha posto preceito de vigiar a terra, e de ir dizer-lhe tudo na confissão, o que se passava, q era p. ${ }^{a}$ melhor serviço de Deus. Fiquei entendendo, que era p. revelar ao Bispo.

A segunda he, que ouvindo a outro de confissão, este me disse, que naquella hora vinha do Mostr. ${ }^{\circ}$ de S.t $t^{\text {a }}$ Cruz de fazer huma confissão sacrilega, em q callára pecados, e porq não queria comungar naquelle estado, se tornava a confessar inteiram. $t^{\circ}$ fora de $S . t^{a}$ Cruz p.. la ir commungar. Perguntando-lhe q cauza tivera p. $^{\mathrm{a}}$ fazer a $d .^{\mathrm{a}}$ confissão sacrilega? Respondeo que elle tinha huma dependencia com o Bispo, e q p. a conseguir era necessar. ${ }^{\circ}$ que elle o tivesse por bem procedido, e q portanto tomára em Sancta Cruz hum P.e espiritual, aquem se confessava a miúdo, mas só de alguã imperfeição, p. o tal confessor assim o vir dizer ao Bispo; e q se tinha alguã cauza grave se confessava primeiro n'outra p.t $^{*}$; e porq naquelle dia não podéra ir primeiro a outra p.t॰ por não perder huã occazião de fallar no seu neg..$^{\circ}$ ao tal Relig. ${ }^{\circ}$ juntam. $t^{\circ}$ fizera a Confíssão sacrilega, de que agora vinha remediar-se.

Hum Clerigo da serra da estrella, cujo nome me não lembra, me disse ha annos escandảlizado, e admirado, que o Bispo o mandára chamar, e lhe perguntára pela vida, e costumes de hum Ordinando, e q respondendo ser de boa vida instára o Bispo, que lhe dicesse a verd. ${ }^{\bullet}$ porq elle seo Confessor, e havia de saber tudo, de que o clerigo disse. q desconfiára lhe perguntára pelo sigillo, e se despedíra do Bispo, dizendo q não sabia mais nada.

Affecta o Bispo grandes escrupulos de couzas levissimas, e nenhum faz de couzas gravissimas, em que não pode haver ignorancia, senão crassa, e supina. Ninguem ignora, q os feitos se devem julgar segundo o allegado, e provado, e não por informações particulares extrajudiciais. Muitas vezes se propozéram feitos na Meza, em q se

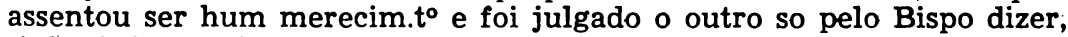
tinha informações em contrario. Nos Esponsais (por mandar o Bispo) era quotidiano condenar a cazar sem legitima prova delles, e só por huãs conjecturas de trato illicito: Nas perguntas dos Esponsáes mandar-se p.a o Aljube ao Reo, que os negava, ou só pelos indicios de trato illicito, ou só por juramento dos País, e Irmãos da Auctora: Nos crimes toda a conducta era condenar sem atender defezas; porq diziam, que na Arca das despezas era necessr..$^{\circ}$ dinheiro

Por exemplo: Hum dos vizitadores fês culpa a hum Pay de Familias só por elle aconselhar a hum seo filho, que não pertendesse cazar com huã moça, a quem ainda não havia fallado, nem promettido, porq dizia o vizitador q o conselho do Pay era impeditivo do S.to Matrimonio; e esteve por aconselhar bem a seu filho culpado, e prezo no Aljube, e no livram. $t^{\circ}$ foi condemnado por sentença em pena pecuniaria, e degredo, approvando, e assistindo o Bispo a tudo. 


\section{O Marquês de Pombal}

Propondo-se afinal outra culpa de hum Reo, se achou em absolvição por mostrar, $\mathrm{q}$ as testemunhas, $\mathrm{q}$ na vizita $\mathrm{o}$ haviam culpado, juráram com nomes suppostos, por não haver táes testemunhas, nem de táis nomes nos lugares, aonde se diziam, moradores; mas porq o d. ${ }^{\circ}$ Provizor disse, $\mathrm{q}$ os proprios nomes, e habitações das testemunhas se haviam occultado, por não convir saber-se quem eram, e q o crime era verdadr. ${ }^{\circ}$ como por informações havia constado ao Bispo, que naquella Meza prezente estava, foi o mizeravel Reo condemnado.

Propoz-se na Meza a petição de huã mulher, em q dizia hum Clerigo de Ordens Menores lhe havião prometido Cazam.to e que ja contra elle tinha justificado esponsáis, como por certidão constava, e q tambem havia querelado delle no secular por desfloração, em q ficára pronunciado, como da mesma sorte por certidão mostrava. E porq tinha noticias $q \circ$ Bispo no dia seg.t $t^{\bullet}$ lhe queria dar Ordens de Epistola pedia q não lhas conferisse em prejuizo do seu direito. Diceram os Ministros ao Bispo, q não lhe devia dar as ditas Ordens; mas o Bispo no diaseg.t ${ }^{\circ}$ lhas deo, e ficou a sup. ${ }^{\circ}$ a olhar p. ${ }^{*}$ o Clerigo ja com Ordens sacras. Depois se fez notorio, q hum Tio, ou Parente do Clerigo havia offertado ao Bispo quatrocentos mil r.: Este Clerigo não me lembra ao certo quem era; só tenho huãs especíes, q não affirmo, de q era hum sobr. ${ }^{\circ}$ de Dionyzio de Macedo de Coimbra chamado o P.e Domingos. No que estou certo he, q o referido se passou na minha prezença na Meza, e que nella se mandaram buscar pelo Guarda os Autos dos Esponsáis, e se vio estarem provados, e que no outro dia cauzou admiração haver-lhe o Bispo conferido Ordens Sacras.

Hum Testador, que cuido, era das partes de Lorvão, deixou em seo testam.to quantid..$^{\circ}$ de dinhr..$^{\circ}$ (segundo minha lembrança) p." dotes de Orfas da sua Freg. a vizinhas, mas sempre eram Legatarias certas: E dando-se conta do testamento no Eccl..$^{\circ}$ quiz o Bispo o dinhr. ${ }^{\circ}$; e por se declarar na Meza que o queria, se lhe mandou dar despacho a titulo do Seminaro, dizendo-se, q tambem era obra pia, e ficaram as Legatarias sem os seus Legados.

A hum Clerigo, cujo nome também me não lembra, vizinho do Mosteiro de S. Jorge dos P." Cruzios, a quem o Bispo havia ja dado as primeiras Ordens, não quiz acabar de ordenar, por elle não querer vender aos Religiosos do d..$^{\circ}$ Mosteiro huma fazenda, $q$ tinha immediata á q. ta $^{a}$ e cerca do Mostr. ${ }^{\circ}$ com que a queríam acrescentar .

Pelo contr.॰ a hum Conego da Sé Thomaz Antonio Brás informou ao Papa, q o despensasse p.a entrar na Sé, não obstante ser neto de Inglez herege, dizendo contra toda a verd. ${ }^{\circ}$ na informação, $q$ elle era de muitas Letras, e virtudes, e com o tal conveniente na Sé, p." ainstruir com a sua doutrina, e com o seo exemplo; ao mesmo tempo, $\mathrm{q}$ das suas virtudes se dizia $\mathrm{m} . \mathrm{t}^{\circ}$ differentem.t' $\mathrm{e}$ as suas Letras eram andar então principiando a estudar Latim, de $\mathbf{q}$ ao depois apreendeo pouco mais do q Lê-lo. E lhe deo Ordens Sacras, dizem q sem Inquirições da parte da Mãy, p." elle ter voto em Cabido; porq segundo he notorio offertou ao Bispo com seiscentos mil reis.

Quando tem empenho, q se lhe devolva o direito de apprezentação de alguma Igr." p." dar a algum dos Clerigos seus Malsins, costuma reprovar ao Apprezentado no exame sinodal. Assim o fez ao Vigr. ${ }^{\circ}$ de Folgozinho, que se callou por appellação; e ao P.e João M.`l Farinha, Capellão da Sé, que levou a Igr.a de Maiorca por opção, e por querer - Bispo q a Opção passasse a outro Capellão, o reprovou no exame, e tambem se collou por appellação. O mesmo fez a outro Capellão da Sé, q levou a Igreja de Tamengos. $\mathbf{E}$ até o fes assim aos seus mesmos Padres Cruzios; porq dando o Regente do Coll..$^{\circ}$ novo a Igr. ${ }^{2}$ de Figueiró dos Vinhos da sua apprenzentação a hum Clerigo seu Irmão, o Bispo 


\section{Miguel da Anunciação}

lhe escreveo, $q$ a desse a outro do seu emp..$^{\circ}$ e pelo Regt' $\circ$ não querer fazer, houve do Bispo p." este, e deste p.a o Bispo cartas algum tanto picantes, as quais o Regente me mostrou. Neste tempo entrou no Collegio novo o P.e Fr. Joze de Meiréles Examinador Sinodal, e sem saber aonde fallava, disse $q$ brevem.t ${ }^{\circ}$ tinha hum exame de hum Clerigo p. $^{2}$ a Igr." de Figueiró dos Vinhos, mas q já tinha recomendação do Bispo p." o reprovar. Ouvindo isto os $\mathrm{P} .{ }^{\circ}$ do d. ${ }^{\circ}$ Collegio, que assim mo contáram, examináram o seu Apprezentado, e o acharam capaz, e ainda o instruíram mais, e depois o mandáram ao exame. Mas sahio o dito verdadeiro, porque foi reprovado, e se collou igualm.t ${ }^{\circ}$ por appellação. Antonio Joze de Souza Oppozitor Theologo na Universid. ${ }^{\circ}$ foi fallar ao Bispo p." Ordenar em tempo habil, e não quiz: foi publico na cid.e que este Oppozitor tivéra seus argumentos com o Bispo, sobre dever ordenar aos Theologos Oppozitores na Univd.' e não teve remedio senão meter-se nos Loios, aonde se ordenou. Vindo a esta Corte, e fallando ao Geral dos Loios, este me perguntou pelo Bispo, estranhando $m . t^{\circ} \circ$ que lhe succedera com elle. Contou-me, $q$ tendo o mesmo Geral aceite ao dito Oppozitor p.a a sua Congreg.am pellas boas informações que tinha delle, o Bispo lhe escrevêra dizendo ,que não aceitasse, porq não só era mal procedido, mas judeo, e q mandára tirar segundas exactas informaçōes, em que achara ser falso tudo, o q mandára tirar segundas exactas informações, em que achara ser falso tudo, o q o Bispo dizia, e lhe escrvêra, e por isso não fizéra cazo da carta, e aceitára o Pertend.

Sempre escreverei o cazo da Beáta, e o do Palio. $O$ da Beáta he, q hum Clerigo, parece-me q das partes de Poiáres, me veio fallar, dizendo $q$ dando primeira vez em hum dia de jubileo pela manhaã a sagrada Comunhão, nella commungára a tal Beata; e q tornando lá pelas nove horas da mesma manhaã a administrar a Comunhão, vira q a mesma Beata tornára a Comungar; e q estando com este cuidado, e tornando pelo meio dia a dar a Comunhão, vira terceira vez á Meza a mesma Beata, e mais se affirmára, que era a mesma, mas que lhe dera terceira vez a Comunhão; e porem viéra logo depois, e chamando-a lhe dicéra: A mim pareceu-me que V. M. comungou aqui nesta manhaã duas ou trez vezes, ao q ella m.t' esperta logo respondera: Sim,

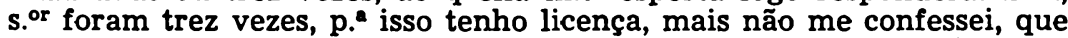
não tinha de que; e q reprehendendo-a o Clerigo ella o ameaçára com o Bispo; eu disse ao Clerigo, q fosse contar este cazo ao Bispo: foi, e tornou a fallar-me, q contára tudo ao Bispo, e q este lhe dicera, que não importava q comungasse trez vezes a tal Beata, porq era huã Santinha, e porq era mais augmento de graça.

O cazo do Pálio he, que se extinguio com o uzo, e com o tempo o que havia na Igreja da Villa de Ancião, com q se administra o Sagrado Viatico aos Enfermos: dizia o Povo q deviam pôr outro os P.• Cruzios, porq apprezentam a Igr. e comem os dizimos: diziam os P." Cruzios, que o devia pôr o Povo. Mandou-me chamar o Bispo, e me disse que por evitar a contenda, mandasse eu fazer hum Palio de damasco de Italia, e que lho levasse com o rol do custo, q me mandaria satísfazer. Eu prezumi q me não havia de pagar (e foi prezunção certa) desculpei-me q não entendia de cedas; q mandásse o mesmo Bispo fazer o Paleo ao seo Alfaate do Paço Marcos Antonio, que faria bem vestimentas, e entendia dessas couzas. Deixou-me, mas mandou chamar a outro seu Dezembarg. or q então era Manoel Roiz da Paz hoje Prior de Trouxomil, e lhe fez a mesma encomenda do Paleo, e promessa de pagar o custo delle. Nesta fé o mandou fazer o pobre Dezembargador, q com eff.t ${ }^{\circ}$ era pobre, e lho levou com o rol da despeza, mas não lho pagou, como havia promettido, dizendo por modo de 


\section{O Marquês de Pombal}

chasco, q o pagasse elle, q lhe estava isto m.to bem por ser Dezembargador de huã Mitra, e q seo Pas era rico, emfim não teve remedio senão paga-lo. Assim mo veio logo contar, lhe respondi o que primr. ${ }^{\circ}$ havia passado comigo, e q não cahíra na Logração.

Huma Freira de Semide me disse q o Bispo indo a este Convento (q he da sua jurisdição) lhe pedira hum ho hanel, que ella tinha, que o queria ver, e mostrando-lhe, elle o metêra no seu dedo, dizendo que aquelle anél estava melhor no dedo de hum Bispo, e q assim lho abafára, e não lho tornára a dar.

Hum dia me chamou o Bispo, e me disse q huma mulher deixára 64000, ou 12800 a N. Sr. ${ }^{a}$ da Orada p. ajuda de hum manto: que escrevesse eu ao cura da dita freg. ${ }^{a}$ que lhe mandasse o dito dinh..$^{\circ}$ que elle cumpriria o Legado: Escrevi-lhe, mandou-me o dinhr. ${ }^{\circ}$ levei-o ao Bispo; não ouvi, q mandasse o manto a N. Sr.a.

Anda sempre pensando em traças de tirar dinhr..$^{\circ}$; qual foi esta tambem. Mandou-me outro dia chamar, e disse porq lhe não dava eu conta do Conego Fulano, o qual na Sé metia mulheres dentro da Caza da Obra, e se fechava com ellas; que logo logo eu lhe desse disto huã conta por escripto: Respondi que tal couza não sabia: Pois sei-o eu, disse elle, e assim vá V. M. fazer a conta, e traga-ma: Respondi, se V. Ex. ${ }^{a}$ o sabe he escuzado a conta: Não he escuzada, disse elle, porq V. M. he o Parocho, e deve constar por conta do Parocho; Respondi, o Parocho principal da Sé he V. Ex.a; e daquillo q sabe escuza conta, nem eu tenho a cura actual, mas só a habitual: Pois a habitual basta, disse elle, e foi teimando, q eu lhe havia de dar a conta por escripto. $\mathrm{E}$ como entendi que elle a queria $\mathrm{p}^{\mathrm{a}}$ a mostrar ao tal Conego, e malquistar-me com elle, e juntam.t' sacar-lhe algum dinh. ${ }^{\circ}$ teimei tambem em que não podia dar conta daquillo q não sabia, como com eff.t t $^{\circ}$ não sabia. Depois observei se elle fazia algum procedimento, ao menos de admoestação verbal, contra o tal Conego, e nenhum fez: queria a minha conta, e conta do q eu não sabia p. lha motsrar, e sacar dinhr. ${ }^{\circ}$. Bem sabido he que tem hido pessoalm. $t^{\circ}$ a caza dos Conegos a pedir-lhe dinhr. ${ }^{\circ}$

O que mais horror me fêz, foi o q succedeo sobre o furto, que se cometteo na Igr. ${ }^{a}$ de Ilhavo. Esta Igr. ${ }^{a}$ ha annos, appareceo roubada; furtaram-lhe alampadas de prata, Cruz grande de prata, Calices, e Cortinados de damasco. Mandouse na Meza proceder a devaça do Sacrilegio pelo Prior de Recardães. Veio nella culpado o Prior, que então era da mesma Igr.a de Ilhavo, cujo nome ja me não lembra, e hum criado fulano Thiago. Propondo-se a devaça em Meza, disse o Bispo, que fosse eu reprogunta-la, e tirar outra, q o Prior poderia estar innocente. Fui, e tirando outra devaça achei prova pleníssima do furto contra o d. ${ }^{\circ}$ Prior; Provou-se q em caza delle foram vistas as cupulas das Alampadas amassadas: que elle mandára dos cortinados da Igr. ${ }^{\mathrm{a}}$ faze-los p." os seus leitos, portas e janellas que amiaçara o juiz ordinario da terra, q não tirasse devaça: que dicera ao seo criado Thiago, q elle o livraria, pois que o mettera naquelle empenho; em fim provou-se, q o Prior se fora ao cofre do liquido das Confrarias, e o quebrára com hum machado, por lhe não querer o juiz da Igr. dar a chave delle, lhe tirará o dinhr..$^{\circ}$, q não era pouco, e o metêra n'algibeira dizendo, que tudo o que era das Confrarias era do Parocho; e que tambem se fora a huma Imagem de N. Sr. que tinha huns cordōes de ouro, os quais the tirára. Estando-se propondo esta devaça na Meza com tão grd. ${ }^{\circ}$ prova, disse o Bispo a queria ver mais devagar; por isso se não pronunciou; ficou-se o Bispo com ella, e a sumio, e ategora mais não appareceo: o Parocho q vinha tão culpado no furto, ficou parocheando como dantes, o delicto impune, e a Igr. ${ }^{\mathrm{a}}$ roubada: Logo se fez publico, que o 


\section{Miguel da: Anunciagão}

Bispo lhe disfarçara este indisfarçavel crime por huns tantos mil cruzados, que elle tinha na Arca das despezas, e havia de levantar della por lhe pertencerem por serem do rendim.to da Igr." do tempo, que esteve vaga, os quais deixára ao Bispo. Toda a freg." de Ilhavo sabe individualm.t' este cazo.

Nem pode haver duvida alguma, que este dito Prior de thavo tinha comprado por bom preço o salvo conducto do Bispo, p. ${ }^{\mathrm{a}}$ ficar indemne daquelle furto da sua mesma Igr.a. Porque provando-se tambem na devaça ser concubinario tão escandalozo, $q$ tendo comsigo na cama as concubinas, neste mesmo tempo que as tinha na cama da mesma fallava aos freg." lhe mostrava a companhr." estando assim tão provado este dezaforo, e affectando sempre o Bispo aversão ás culpas libidinozas, nenhuã teve a esta, assim como nenhum horror lhe fez o sacrilego furto, e nada o moveo p. ${ }^{\mathrm{a}}$ mandar pronunciar a devaça.

E ainda digo que o dito Prior devia comprar, e comprou por bom preço a sua impunidade. Porquanto indo eu a Ilhavo, me viéram fallar á vista alegre alguns Clerigos, e o mesmo Cura do Prior, dizendo este se achava excomungado vitando nas portas da Igr. por huma sentença de Braga, cumprida no mesmo juizo Eccl. ${ }^{\circ}$ de Coimbra, havia m.t ${ }^{\circ}$ tempo, zombando da censura, e parochiando excomungado, e q elles Clerigos não podiam comunicar com elle, e tinham vexação em andarem a dizer Missa por Capellas por se não encontrarem com elle na Igr. e o cura estava em maior consternação, por não poder deixar de ir á Igr.a nem tolher o dito Prior, q fosse a ella, como hia celebrar os

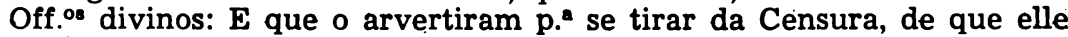
se ria, dizendo ser nulla, e que replicando-lhe q pedisse vista p. ${ }^{\mathrm{a}}$ mostrar a nullid. ${ }^{\bullet}$ e absolvição ad cautellam entretanto, e por evitar o escandolo, não se demovia a couza alguma; pelo que me requeriam q eu procedesse contra elle ao menor p.a que não fosse á Igr. ${ }^{a}$ emquanto estivesse excomungado. Ao q respondi se tinha o cura dado conta ao Bispo, e respondeo $q$ sim, mas sem eff.t ${ }^{\circ}$ e eu lhe disse, $q$ não podia proceder sem primr. ${ }^{\circ}$ falar ao Bispo; porq os Dezembargadores da Meza não tinham delle licença p. $^{\mathrm{a}}$ similh. $\mathrm{t}^{\mathrm{s}}$ procedim.tos sem primeiro lhos propôrem, q eu hia p. ${ }^{\mathrm{a}}$ Coimbra, e faria tudo prez.t ${ }^{\circ}$ ao Bispo p. ${ }^{\mathrm{a}}$ dar provid. . Fui p." Coimbra, e passando de caminho pela porta da Igr." de Ilhavo, nella vi fixada huma Declaratoria, ou de participantes contra o dito Prior. Cheguei a Coimbra, fallei ao Bispo, expondo-lhe o referido, e que era necessr..$^{\circ}$ mandar denunciar o Prior por não recorrer, e desprezar a Censura, e estar incurso em irregularid. ${ }^{\circ}$ por celebrar estando censurado. Respondeo $q$ ja tinha dado providencia, e nenhuã tinha dado, nem deo, e he publico, que o tal Prior vindo a esta Côrte excomungado, morrera no terremoto: $O$ certo he (como he tambem notorio) que comprou a bom preço o desfarse de tais crimes; Estes são os escrupulos do Bispo engulir couzas tão graves em havendo dinhr. ${ }^{\circ}$

$\mathrm{Na}$ execução das Ordens Regias, supposto se mostre conforme, e se reprima, certam. $t^{\circ}$ não obedece de todo o seu coração. Ainda hoje está teimando nas feiras, e nos touros p. prohibir, não obstante as Reais Ordens, q teve, ainda que não descobertam.t.'. Athe o prezente, aonde sabe ( $q$ ha touros. (menos só na V.a de Abiúl, a que foi o Real Decreto, como se não devesse praticalo geralm.t.) esta chamando Clerigos, e Parochos seus Confid.tea, e recomendando que os impidam da sua p.t. Quando em Coimbra os houve, e outros festejos pelo Nascimeneto do Princip, q D. guarde, ou do S.or Infante, ou de ambos as mesmos snr..$^{\circ}$ expressam. $t^{\circ}$ os prohibio mandando pôr os seus officiáis de Justiça na Ponte, e ao Castello com Ordem que prendessem, e trouxessem p.a 0 Aljube a todo o Clerigo que la fosse, de que os Clerigos: 


\title{
O Marques de Pombal
}

năo fizeram cazo; e porq os officiais do Bispo se năo attrevêram a prende-los, ficou o Bispo blasfemando contra huns, e outros. $\mathbf{E}$ quando se descobrio a infidelid. ' dos Jezuitas, e S. Mag. mandou proceder contra elles, não deixou de dar o Bispo indicios de sentim.to pelos mesmos Jezuitas, e se fez em Coimbra por alguãs pessoas reparo, assim na mora, com q sahio com a Pastoral da suspensão delles, como em se explicar nesta por huãs palavras tão concizas, e languidas de frouxidão, e pouca vontade.

Estes os factos, que por ora me lembram, e como o respeito, e a reverencia me não deixaria dize-los de palavra com tanta individuação, o referido por escripto.

Neste papel cheyo de mentiras e calumnias mostrou o Autor não só ser mais ingrato do que Judas, pois tendo elle recebido os mayores beneficios do Santo Bispo D.r D. Miguel da Ann.ão o qual de simples ordinando o levantou a ser Dezembargador da sua relação e depois lhe deu a meya conezia na sua Sé, favorecendo-o mais que a todos os outros Ministros; correspondeo com tantas calunias que o Demonio lhe sugerio. Depois da soltura do d. ${ }^{\circ}$ Santo Bispo, e S. Ex." o tractou com a maior benevolencia, e carid. ${ }^{\circ}$ Deos lhe tenha dado verdadr. ${ }^{\circ}$ arrependimento antes de o chamar para o seu juizo.

\section{A. U. C., Documentos Vários}

\section{XII - ORAÇĀO FUNEBRE DO EXM.ค SR. BISPO DE COIMBRA D. MIGUEL D'ANNUNCIAÇAOO}

\author{
Ecce sacerdos magnus, qui in \\ diebus suis placuit Deo, et \\ inventus est justus.
}

Eis-aqui um sacerdote grande que nos seus dias agradou a Deus, e foi achado Justo. Eccles. 44.

Que esperaes vós, senhores, do meu ministério n'esta hora? Acaso que eu venha renovar em vossos coraçōes o sentimento de uma morte, que a todos nós tem consternado? que vos pondere como com a falta de uma só vida cujo fim lamentamos, faltou para innumeraveis vidas o seu estabelecimento? que falleceu com ella para os peccadores uma luz; para os pobbres o sustento; para os enfermos o alivio; para os desamparados o soccorro? quereis, que vos faça perceber os gemidos dos hospitaes, os suspiros dos mosteiros, as lagrimas dos orphãos e viuvas pela morte d'aquelle que para todos era um amigo fiel, uma protecção forte, um thesouso?

Esperaes, que ajuntando os meus sentimentos aos de toda esta diocese, deplore n'este logar a desgraçça de termos perdido um pae caritativo, um pastor vigilante, um prelado completo, que era uma copia dos padres antigos um exemplar das virtudes, um digno successor dos apostolos, emfim que era (n'isto digo tudo) o muito alto e illustre principe da egreja o ex. ${ }^{\text {mo }}$ e rev. ${ }^{\text {mo }}$ sr. D. Miguel da Annunciação, bispo de Coimbra e conde de Arganil, a cuja saudosa memoria se dedicam estes funebres obsequios? Por este grande homem, choraes aqui em publico? Eu farei que com os vossos gemidos celebreis a sua memoria. Sim, irmãos meus, esse seria o meu emprego, se outro não fosse o seu merecimento. $O$ sr. D. Miguel, de tal sorte soube conduzir-se 


\section{Miguel da Anunciağão}

pelos caminhos da vida mortal, que se fez mais credor dos nossos elogios, do que das nossas lagrimas. Não sois vós mesmos os que confessaes, que elle foi um varão justo, um prelado santo, que teve uma vida perfeita, que acabou com uma morte preciosa? Eis aqui pois o mesmo, que vos obriga a pôr termo aos sentimentos, para dar lugar aos seus louvores.

Condescendei pois antes com os desejos do Espirito Santo, ajuntae-o ao numero d'queles varões gloriosos, em cujas acclamaçöes quer elle ver occupados assim os individuos da plebe como os ministros da Igreja - Sapientiam ipsorum narrent populi, et lauden eorum nuncit ecclesia - Dae graças ao Senhor, que o santificou, honrae-o como a um exemplar de virtudes heroicas; confessae, que se vos falta emquanto á presença, ainda o tendes vivo na memoria de suas acções tal qual elle foi, e a escriptura nol'o descreve em as palavras, que tomei por thema. um grande sacerdote da Egreja, que soube merecer os agrados do Senhor, pelas virtudes que exercitou mais dignas do seu estado.

Assim é senhores; elle foi grande e foi virtuoso. Por mais que estas duas qualidades sejam dificeis de coadunar-se, n'elle se viram tão juntas e unidas, que a grandeza serviu a virtude, e a virtude cooperou para a grandeza. Quero dizer, que elle sacrificou em beneficio da virtude toda a sua grandeza, primeiro ponto; que a virtude o metteu na posse de uma grandeza em tudo a mais feliz, e mais gloriosa: segundo ponto.

Eis aqui as duas partes do elogio com que eu pertendo hoje honrar a sua memoria, e mover em seu beneficio os vossos obsequios. Permitta o ceu, que eu falle tão dignamente nas suas virtudes, que quando não eguale, ao menos não offenda o merecimento de um tão illustre heroe.

Muitas foram na verdade as grandesas, que na pessoa do ex. ${ }^{\text {mo }}$ sr. D. Miguel depositou o Supremo Arbitro das fortunas dos homens. Nós se olhamos para o berço do seu nascimento reconhecemos n'elle uma nova flor da nobreza de Portugal, que brota d'um tronco illustre que estendendo desde o tempo antigo cada vez mais os seus brilhantes ramos, em todos se vê coroado de honra e de gloria: um tronco de que a patria tem colhido immensos serviços; os soberanos magnificos obsequios; e a mesma Igreja muitos exemplos de virtude. Vemos, senhores, que elle descende da antiga nobilissima, e sempre illustre casa dos srs. condes de Povolide, e isto basta para o respeitarmos como um grande d'este reino.

Se atendemos para o progresso dos seus estudos, occupação, em que desde os tenros annos se exercitou, nós o achamos na flor da idade, antes de cumpridos vinte e tres annos servindo de admiração à mesma universidade de Coimbra, que gostosa lhe põe a borla na cabeça, honra-o com uma conduta, e talha n'elle um mestre para as suas cadeiras, e um grande para o seu claustro. Se o contemplamos adornado com o habito de conego regrante, nos claustros do grande Agostinho, admiramos n'elle um digno successor d'este santo patriarcha, um capitão do povo escolhido do Senhor, um geral da Santa Cruz. Consideramol-o emfim no estado pontifical, a que foi elevado, e em que concluio felizmente a carreira dos seus dias e n'elle veneramos a um principe da egreja e do estado: bispo de Coimbra, um conde de Arganil, um grande no imperio, e na egreja.

Mas se nós nos viramos para o uso, que elle fez de todas estas grandezas, para o heroico das acçōes de catholico, que no meio de tantas honras exercita: que outra cousa vemos nós, senão um perenne sacrificio de todas ellas nas aras da virtude? Sim, meus irmãos, quanto mais a fortuna se empenha em exaltal-o, tanto mais se empenha elle 


\section{O Marquês de Pombal}

em lançar aos pés do cordeiro immaculado; todas as coroas da sua gloria, e da sua grandeza. Ide por partes analisando as suas acções, e vós o vereis claramente.

Vereis que quando elle na flor da mocidade aos vinte e quatro annos de vida gosava na celeberrima universidade de Coimbra os respeitos de grande pela origem, e de admiravel pela sabedoria; quando uma indole capaz de emprezas magnificas o lisongeava, com bem fundadas esperanças de novos acrescentamentos de honra, e de gloria, para a sua pessoa; quando o mundo e a fortuna principiavam a abrir em seu favor os thesouros; então mesmo é que elle sem reserva sujeitou quanto possuia, quanto esperava, e quanto era, áquella penetrante espada que no mundo veiu lançar o filho de Deus, para com ella ser destruido em seu obsequio, quanto no mesmo se oppóe ao abatimento da sua cruz.

Renuncia toda a gloria da terra, troca a beca de S. Paulo pelo habito da religião, deixa a casa de Povolide pelo retiro de um mosteiro, foje do claustro da universidade para o de Santa Cruz, vae por meio da profissão religiosa negar-se a si proprio, e entregar-se para sempre á sujeição, e arbitro de um estranho. Vae emfim pelo desprezo de tudo fazer-se capaz de dizer a Jesus Christo com o principe dos apostolos - Ecce nos relinquimus omnia, et secuti sumus te - Eis-aqui um sacrifico que consome em obsequio da virtude quanto elle tinha aos olhos do mundo de mais estima.

Não entendaes porém, senhores, que com elle se dá já por satisfeita a valentia do seu coração. Agora que elle se vê já dividido do seculo e dedicado á religião e á virtude, è que procura cada vez mais certificar-se da verdade da sua vocação, e concluir com inteiresa a perfeição do seu sacrificio. Elle entra a exercitar-se tanto deveras na humildade do coração, na mortificação da carne, na pobresa do espirito, na obediencia, na modestia, no retiro, na pureza da alma, que mostra a Deus e ao mundo; que se não contenta com ter destroçado as flores, e os ramos da mundana vaidade, que quer que o seu sacrificio abranja ao mais profundo das suas raizes, a todos os affectos, e resaibos de grandeza com que ainda podia ser accometido.

Verdade é que a maior parte d'estes particulares sacrificios, nos são ainda occultos, e que muitos d'elles (e talvez os mais preciosos) só os pode ver. quem os pode premiar; mas comtudo nós sabemos que elle se portou de tal sorte em os fazer perfeitos, que passados bem poucos annos aos nove de religião, e trinta e trez de idade, que prodigio! a mesma illustre congregação que o adoptara por filho, e discipulo, o achou capaz de ser seu pae, e seu mestre, e seu prelado geral. Isto basta para credito da sua virtude, e para persuadir-nos que apesar de seus poucos annos elle era já no principio de uma reforma strictissima, e no meio de tantos varōes illustres, como n'ella se exercitavam, o mais digno de ser o espelho, o exemplar, o mestre, o guia a luz de todos elles. Mas eil-o ahi já por isso mesmo com uma nova materia em as mãos para expendel-a em novos sacrificios. $€$ geral de Santa Cruz. Domina como prelado nas vontades de todos os alumnos d'aquella illustre sociedade, governa em todo o seu alvedrio.

Corre pela sua mão a destribuição de avultados reditos. um grande nos claustros de Agostinho. Mas de que serve tudo isso nas mãos do sr. D. Miguel? De vermos n'elle o primeiro servo de todos os seus subditos. Um assistente commum dos enfermos. Um procurador diligente do que necessitam todos os individuos da communidade. Um apostolo da pobreza tão egregio, que chega a vender os livros do seu uso para soccorrel-a. Serve de vermos mais crescido o seu exemplo; a sua mansidão, a sua humildade, a sua caridade, todo o conselho das 


\section{Miguel da Anunciegão}

suas virtudes. Eis-ahi a grandeza do generalato sacrificada ás virtudes do claustro, e elle mostrando-nos no fructo do seu sacrificio uma imagem perfeita do que Christo recomendou aos apostolos quando lhes disse: que o maior entre elles fosse de todos o servo - qui maior est vestrum erit minister vester.

Ações tão illustres não poderam escapar á prespicacia das attenções com que o senhor $\mathrm{D}$. João $\mathrm{V}$ de gloriosa memoria contemplava os merecimentos dos seus vassallos. Elle as vê, elle reconhece que para coração tão generoso no serviço do Altissimo, é muito curto o plano de uma congregação de religiosos, aliás dos mais illustres d'este reino. Quer promovel-o a outro mais digno de sua pessoa e elle o nomeia prelado da maior diocese. Condecora-o com um titulo honorifico, e fal-o Senhor de terra. Em uma palavra, fal-o Bispo de Coimbra, conde de Arganil, sr. de Coja. E ahi temos o sr. D. Miguel outra vez numerado entre os grandes do reino, e feito um principe da Egreja, ou para melhor dizer já o vemos com mais materia em as mãos para continuar a serie dos seus sacrificios, com meios avultados para fazer subir de ponto o seu zelo pelas almas, a sua piedade para com as pobres, e o seu desapego dos bens da terra, a sua modestia, a sua humildade, a sua paciencia, a perfeição da sua alma.

Assim é senhores, em quasi quarenta annos que elle gosou d'estas dignidades, nós não vemos que elle fizesse de toda a sua grandeza outro uso, mais que aquelle que a virtude lhe prescrevia. Quanto tem, quanto pode e quanto é todo sem reserva se sacrificão ao cabal desempenho das virtudes que são proprias do seu caracter. $O$ zelo pastoral que elle tem da salvação das almas, que lhe são cometidas, jamais lhe permitte um só instante de descanço. Elle o faz assistir de continuo ou no despacho, ou no oratorio. N'aquelle para dar as providencias que a sua sabedoria lhe ministra; n'este para pedir a sabedoria increada, que supra com a sua graça, o que elle não pode abranger com as suas deligencias.

O.zelo o faz girar continuamente pela sua diocese, atropelando difficuldades, trabalhos, e perigos: vadeando por montes, valles e serras; despresando as calmas, as neves e as chuvas; não fazendo caso da incommodidade das aposentadorias, nem da prolixidade das suas queixas, nem da dibilidade de suas forças, só a fim de poder elle por sí mesmo visitar as egrejas, instruir os parochos, ensinar aos meninos, consolar aos aflictos, animar aos virtuosos, soccorrer aos necessitados. Vós senhores sois as testemunhas, vós o vistes.

Elle reconhece que d'onde depende principalmente o aproveitamento das ovelhas, que estão dispersas pelos povos é da santidade e litteratura dos ministros subalternos, que lhe são enviados. Sabe igualmente, que sem estes terem uma fonte perenne, aonde todos vão beber estes grandes dotes, de que necessitam, não se pode dar cabal providencia á sua instrucção. Eis-ahi o seu zelo que o obriga a dispender immensas sommas, para fabricar aquella magnifica casa do seminario de Coimbra, que será um perpetuo padrão da sua magnificencia por todos os seculos da posteridade.

Para ali convoca elle mestres de reinos estrangeiros: manda á sua custa estudantes a Paris, que tragam para a sua diocese as letras que ali florescem com universal acclamação da Europa. Empenha-se em que ali se ensinem as doutrinas mais puras com as virtudes mais solidas. Perpetúa com grossas rendas o seu estabelecimento, a fim de que por todo o tempo que durar o munda, seja aquella casa uma torrente de sabedoria evirtude, que por meio da instrucção do clero, que ali se ministra, regue para sempre o seu bispado, o illustre, 0 santifique, e dirija para o céu. 


\section{O Marques de Pombal}

O zelo o faz andar á caça das creaturas mais perdidas, obrigando ainda com força de prisão as mesmas meretrizes, a assistirem ás praticas de piedade, e a ouvirem as reprehensões dos confessores, que lhes dava para tiral-as do caminho da perdição. $O$ zelo emfim o faz morrer fóra de seu palacio, em uma casa alheia, acabando a vida em Semide no meio dos exercicios appostolocos, em que ahi se occupava. Eis-aqui o que nos faz certos, de que Elle podia clamar ao Senhor com o psalmista - Zellus Domus tuae comedit me - O zelo da vossa casa, Senhor, me consumiu, me acabou e me comeu.

Não menos obrou n'elle o cuidado, que tinha de soccorrer aos pobres e aos enfermos. Aqui haviam de falar os conventos, os hospitaes, os recolhimentos as cadeias, as parochias, Semide, Louriçal, Paço do conde, Tavarede, os orphãos, as viuvas, as pessoas envergonhadas, os curatos tenues, todas as necessidades d'este bispado. Nós veriamos taes monumentos da sua liberalidade, que nós nos admirariamos, de como podiam chegar a tantas expensas os reditos da sua mitra, ainda que tão opulentos.

A verdade é, que nenhuns outros foram os seus possuidores, que raro será o sacerdote, convento, ou Igreja, aonde se não achem livros, ou outras alfaias, que elle désse: que as congruas, que acrescentou, as esmolas particulares, que repartiu foram immensas. Estes, e não outros foram os seus morgados e os seus thesouros, e ainda as alfaias do seu palacio. Sim, irmãos meus, alheio estava este de toda a pompa e vaidade. A cama do seu uso era mais propria para um religioso, do que para um principe como elle. No serviço da sua mesa não entrava de prata nem um só garfo: os seus trastes mais estimados, eram as disciplinas, e os cilicios. Era tal a sua pobresa que encheu de espanto aos mesmos ministros da justiça, quando o transferiram para o carcere, ficando egualmente admirados de que constasse do seu livro da rasão que n'aquelle anno tinha expendido em beneficio da pobresa quarenta mil crusados.

Emfim, senhores, o senhor D. Miguel para soccorrer aos pobres chegou a fazer-se pobre a si mesmo. Não tendo que dar em uma occasião, deu a sua capa magna. Em outra tirou as botas para entregal-as a um necessitado, recolhendo se descalço para o seu aposento do campo em que se achava: em outras pediu emprestado para dar de graça, e em muitas chegou elle mesmo em pessoa com a sua familia, e alguns religiosos, a andar pelas portas e ruas de Coimbra, com ceiras nas mãos tirando esmolas para os enfermos e encarcerados, que elle mesmo lhes ia distribuir nos asquerosos carceres aonde existiam: Eu o vi, e eu tive a honra de acompanhal-o, quando Elle cumpria com este exercicio em a cadeia da Portage de Coimbra. Diga pois o senhor D. Miguel, diga, que bem pode com o Santo Job: Eu fui os olhos para o cego, os pés para o aleijado. Eu fui o consolador da viuva, eu fui o protector do projecto. Eu fui o pae de toda a pobreza. Oculus fui coeco, et pes claudo, Pater eram pauperum. E que foi isto tudo senão um sacrificio, que Elle fez á virtude de todas as grandezas, que a graça, e a fortuna lhe consederam.

Mas vós ainda não vistes tudo; que direis se ouvirdes expor a liberdade, a pessoa, a vida, em beneficio da egreja que lhe foi cometida? E não foi isto mesmo que elle fez? vós o sabeis, senhores, quem o fez descair, não tanto da graça do Rei, como de quem soube valer-se do seu poder, para perseguir aos innocentes? que o rei sempre foi fidelissimo á Egreja. E quão recto fosse o seu coração em tudo nas acçōes heroicas, que na morte executou, claramente o fez ver: Eu fallo 


\section{Miguel da Anunciação}

cam asipalavras da Santissimo Padre Pio VI. - Omnibus ostendit quam recto fuerit corde, quanta vi semper religione flagravit ( $\left.{ }^{1}\right)$.

Quem o fez ser preso com ignominia, lido por desgraçado, tratado como morto? quem o fez existir oito annos nos horrores de um carcere apertado e devidido do consorcio das gentes, despojado das honras, privado da mitra, feito a fabula dos mal intencionados, a irrisão dos libertinos, o objecto dos opprobrios. Quem, se não o zelo Pastoral das suas ovelhas, com que quiz desterrar da sua diocese o pasto venenoso das doutrinas novas, e menos vãs, e das quaes chegou ainda a ver algumas condemnadas por seu proprio Anthor? E que vedes vós aqui, senhores, senão uma consummação dos seus sacrificios? Quem sacrifica as honras, as dignidades, os reditos, o descanço, a liberdade, o que tem, e o que é, nada mais lihe fica.

Isto pois fez o sr. D. Miguel, e assim mostrou que n'elle vivia Christo, e não o mundo; que a sua caridade era aquella de que em outro tempo se gloria o Apostolo, a quem não derribam nem as tribulações, nem as angustias, nem os perigos, nem os temores, nem a fome, nem a nudez, nem as espadas, nem a morte e nem a vida. Com isto mostrou que elle era um pastor tal, e qual Jesus Christo o quer, que não teme expor a propria vida para defender da morte as ovelhas. Bonus pastor animam suam dat pro ovibus suis. - Confessemos, pois, que o senhor $D$. Miguel foi na verdade um grande, que nada teve que não sacrificasse ao exercicio da virtude. Deixou a casa, a familia e patria pelo seguimento de Christo na religião; trocou os applausos da universidade, e as esperanças do mundo pelos retiros do claustro: abateu a dignidade de geral ao serviço de seus irmãos; empregou a de Bispo em trabalhos apostolicos: entregou as rendas da sua mitra e do seu condado aos dominios da caridade. Expoz a liberdade, e a pessoa por não deixar perder as ovelhas do seu rebanho. Que lhe faltou para sacrificar-se de todo? Eis aqui porque eu vos dizia ao principio, que elle sacrificou em obsequio da virtude, a grandeza com que a fortuna o favorecera.

Não entendais porem, que elle deixa por isso de merecer, e possuir os creditos de grande, e as acclamações de principe. As mesmas virtudes a quem elle sacrificou toda a sua grandeza, são as que fazem que elle a torne apossuir muito mais estimavel, e muito mais gloriosa: esta é a materia da

\section{SEGUNDA PARTE}

Por mais que a politica mundana o contradiga, elle sempre hade ser certo que o caminho mais direito para a exaltação é o abatimento. Vós o dissestes, meu Deus... qui se humiliar exaltabitur, e com isto nosas seguraes do mesmo, que eu vou mostrar no objecto d'este elogio: que o meio de segurar uma grandeza constante, apetecivel e verdadeira, éabatel-a aos pés da vossa cruz, sacrifical-a aos exercicios mais baixos da virtude.

Com effeito esta foi a fortuna do senhor D. Miguel. Nas aras da virtude sacrifica elle toda a sua grandeza sem reserva. Vós já o vistes; mas não a recebeu elle muito mais melhorada por isso mesmo? Eu não fallo aqui da grandeza que na gloria alcançam, os que por Jesus Chris-

(') In alocutione habita in consistorio cardinalium, qua Mortem nostri fidelissimi regis illis denunciavit die 12 maii, 1777 et si plura alia de hac re. 


\section{O. Marquềs de Pombal}

to se humilharam, e de que piamente cremos, elle gosa, ainda que de certo o não sabemos, emquanto a Igreja o não difine; fallo sim d'aquella gloria, que elle gozou cá no mundo, e que tanta materia lhe deu para os seus sacrificios: quero dizer, que se a virtude o obriga a occultar a gloria do seu nascimento, a tratar como servo, sendo principe, e a parecer pobre sendo rico, a ser prezo como malfeitor sendo innocente, a soffrer escarneos, irrisões e ignominias, sendo digno das acclamaçôes dos homens: a mesma virtude o tornou a metter de posse de quanto perdera muito mais melhorado. E senão vede. Antes que o senhor D. Miguel chegasse ao ultimo dos seus sacrificios, sim era um bispo de Coimbra, um conde d'Arganil, um principe; mas quasi que aqui terminava toda a sua grandeza. Elle na presença das Magestades não faz figura mais do que a ordinariado seu carater; pelo seu ministerio é muito pouco attendido. O reino não o celebra: os paizes estrangeiros o ignoram: muitos dos seus subditos o não amam: outros se lhe estão sujeitos é mais por necessidade que por amor. Chega talvez a ser desprezado por fanatico: a sua gloria está muito languida o destricto a que se estendem os applausos, que merece, é sem duvida muito lemitado.

Tanto que elle sacrificou quanto tinha e quanto era ao zelo pastoral do seu rebanho, tanto que elle é arrancado da cadeira episcopal que possuia; tanto que elle sae pelas ruas fóra da cidade de Coimbra na figura de delinquente, preso no meio de uma escolta de soldados; tanto que os sinos da sua sé ouvem com brados funebres publicar vaga a sua cadeira; tanto que elle se vê nos horrores de um carcere apertado, sem bispado, sem honras, sem rendas, sem familia, sem amigos: Eis ahi logo chegam os brados da sua grandeza, e da sua gloria a retumbar com admirações no mespo palacio vaticano: e a encher-se de assombro toda a Roma, Italia, Allemanha, França, Hespanha e Portugal; toda a Europa fiel celebram com admirações os seus louvores. Os subditos que o aborreciam já em verdade se protestam seus amantes e choram com o maior sentimento a sua falta: os que o não eram, invejam a nossa dita: que mais, senhores, os esplendores da sua virtude brilham com tanta força lá desde a escuridade do carcere, em que existe, que elles chegam a ferir o real throno. Ahi desfazem as nuvens que impediam a um rei fiel, e amante da patria e dos vassallos a conhecer a verdade da sua innocencia. E como elle estimava em tudo a justiça, e a verdade sem alguma attenção a razôes de estado, immediatamente que a conhece lhe concede a liberdade, as honras, as dignidades, e os titulos que antes tinha: Eil-o ahi toma posse de quanto perdera, juntamente com um absoluto dominio sobre os coraçôes de todos os vassallos d'este reino.

As magestades são as primeiras que o veneram com o respeito mais profundo: os grandes da corte todos cordialmente o estimam: o povo o sauda com maior jubilo. Chega senhores depois de restituido a sua cadeira a ver prostrado a seus pés pedindo-lhe a benção como subdito, aquelle mesmo que é reputado pelo Aman, que d'ella o tinha arrancado; quem o mandou reputar por morto, que mo conduziu aos horrores do carcere. Que mais? a virtude faz com que elle acabe a vida cheio de glaria, com uma morte preciosa aos olhos dos homens, e quanto entendemos, também aos de Deus. E se chegou a occasião de perdermos um tão grande Prelado, tambem chegou o tempo de vermos mais estendida a fama de seu nome. Grandes e pequenos o acclamam por santo, ou por grande no reino do Senhor ,e já que não é possivel gozarem da sua presença: procuram todos á porfia possuir alguma parte das alfaias que foram de seu uso para nellas conservarem uma perpetua memoria da sua grandeza. O seu sangue se recolhe em lenços, 


\section{Miguel da Anunciação}

e se divide em immensidade de pedaços pelos muitos que o pertendem: as suas roupas se estimão como reliquias: e até se diz que as magestades mandaram pedir os seus roquetes para dar-lhe a mesma estimação: o escuro de seu carcere se visita com devoção e n'elle se beija a terra, que até pizaram as suas plantas: até aquellas pobres alfaias que ahi deixou: O enxergão, senhores, o enxergão da sua cama se faz em retalhos, para como elles contentar aos muitos que d'elle procuravam uma lembrança. Eis aqui convertido em gloria o mesmo que lhe servia de ignominia.

O ceu mesmo parece de empenho com prodigios em mostra-lo grande aos olhos dos homens: é bem verdade que eu não posso prégar milagres suppostos, nem tenho jurisdicção para asseverar por verdadeiros os que do senhor D. Miguel se referem; mas eu não posso impedir a fama de seus eccos. Ella clama que elle depois da morte apertára a mão a um seu amigo particular, quando este com reverencia lhe pegou para beijal-a: que se encommendára a elle e sarára em Santa Anna uma religiosa entrevada: que com uma sua reliquia repentinamente escapára das fouces da morte uma religiosa em Carnide depois de ungida: que com o contacto das suas alfaias se curaram gravissimas e antigas dores que padecia certa pessoa que com devoção a si as chegou, que no seu sepulchro deixára um aleijado as suas moletas que o seu corpo ficára flexivel; que depois de vinte e duas horas defunto deitava sangue liquido, que se cuida com diligencia em authenticar muitos prodigios seus. Isto é o que a fama publica diz. Deixemos muito embora ao tribunal da egreja o sentenciar da sua verdade. $O$ que é para nós muito certo, é, que tudo isto dá um novo explendor ás grandezas do senhor D. Miguel: e que a virtude lhe restituiu estas muito mais estimaveis do que as que antes possuia. São os explendores que nos obrigam a esperar, que a sua exaltação se estenderá por todos os povos da Egreja, e por todos os seculos da posteridade para permanecer em perpetua memoria nos corações dos homens. Assim o promette Deus ao justo, e assim nol-o promette a nós a justiça, que elle executou - In memoria aeterna erit Justus -

Dai-vos pois já, meus irmãos, por satisfeitos do que eu ao principio vos prometti: Venerai ao sr. D. Miguel como a um grande, que dedicou a virtude á grandeza. $\mathbf{E}$ para não permitirdes que o silencio da sua sepultura possa em algum tempo dar causa ao esquecimento de um tão grande heroe riscando todos os mais epitaphios, gravai sobre ella este, que eu vejo dedicado á sua memoria em todos os corações de quem oconheceu - Aqui jaz o exemplo dos prelados, o desempenho da nobreza, a honra dos pastores, um principe da Egreja, um sacerdote grande; é um grande da casa do Senhor, que nos seus dias soube agradar a Deus, e na sua morte foi reputado justo - Ecce sacerdos magnus, qui in diebus suis placuit Deo, et inventus est Justus.

Amen.

A gratidão é o unico thesouro dos pobres.

In O Thesouro dos Oradores, n. ${ }^{\circ} 26$ a 32 , de 1869. 


\section{O Marquês de Pombal}

\section{OBITO DE D. MIGUEL DE ANUNCIAÇAO}

Aos vinte nove do mez proximo de Agosto pela huma hora e meia de vespora falleceo com seu Juizo m.t ${ }^{\circ}$ claro e vista clara o Senhor Bispo Dom Miguel da Anun-

Coimbra

D. Miguel

Bispo

Conde

$q$
faleceo

com opi-

nião de

Santo cicam comiguo Regullar de Santa Cruz de Coimbra o qual havia dois annos e seis mezes que tinha sahido com m.to triumfo do carcere e que teve de outo anos e tres mezes morreo com todos os sacram.tos elegeo na minha prezença a sua sepultura no altar de N. Senhora da Conceicam da Igreja de Santa Cruz enfermou a 24 de Agosto no dia de S. Bartholomeu neste dice misa crismou todos os que se achavam por crismar desta freg. ${ }^{a}$ e Rio de Vide que a esta Igr. ${ }^{a}$ mandou vir da qual obrigacam sahio m.to fatigado pella huma hora depois do meio dia e nesa tarde fes huma pratica aos clerigos sobre As meditaçoens do inferno as intranhas ficaram enterradas no presbitero da parte do Evangelho desta Igr.a de que fiz este acento dia mes $\theta$ anno ut supra.

O cura João Gomes

A.U.C., Livro de assentos de óbitos de Semide, 1752-1804 , fl. 78 v. ${ }^{\circ}$.

\section{XIII - ALGUMAS PASTORAIS}

\section{PASTORAL DE 11 DE JANEIRO DE 1742 (SOBRE O JEJUM)}

J. M. J.

DOM MIGUEL DA ANUNCIAÇÃO CONEGO REGULAR DE S. AGOSTINHO da Congregação reformada de Sancta Cruz, por mercê de Deos, e da Sancta Sé Apostolica Bispo de Coimbra, Conde de Arganil, Senhor de Côja, do Conselho de Sua Magestade, \& c.

A todos os que esta nossa Carta Pastoral virem, ou della noticia tiverem, saude, e paz em JESU CHRISTO, que de todos he verdadeiro remedio, e salvação. Fazemos saber, que em observancia do Decreto Apostolico do nosso Sanctissimo Padre o Senhor BENEDICTO XIV. Presidente da Igreja de Deos, a respeito da fórma, entre aquellas pessoas, aquem he concedido este privilegio por legitima causa, o mandámos publicar, recommendando muito apertadamente a nossos subditos o observassem inviolavelmente; e porque agora nos envia Sua Sanctidade segundo Breve em confirmaçaō, e declaraçaõ do primeiro referido, o mandámos traduzir da lingua Latina no nosso idioma, para melhor intelligencia, cujo theor he o seguinte.

A TODOS OS VENERAVEIS IRMAOOS PATRIARCHAS, PRIMAZES, Metropolitanos, Arcebispos, e Bispos, que participaõ da graça, e communicaçaõ com a Sé Apostolica,

\section{BENEDICTO PAPA XIV}

Veneraveis Irmãos, saude, e benção Apostolica .

CONSTITUIDOS Nós no Supremo governo da Igreja universal, ainda que sem merecimentos nossos, pela ineffavel abundancia da $\mathrm{Di}$ vina bondade, naõ menos, como vigilantes zeladores da disciplina 


\section{Miguel da Anunciação}

Ecclesiastica, que defensores da Fé Catholica; desejando tirar a corruptela do jejum nos tempos presentes, e restituir á sua antiga observancia, quanto for possivel com a graça Divina, o jejum, principalmente da sagrada Quaresma, o qual todos os Catholicos confessaõ ser hum dos principaes mandamentos sempre, e em toda a parte observado desde o principio da Igreja, tractámos com cuidado de excitar, Irmãos Nossos, vosso fervorosissimo zelo com outras letras, que em similhante fórma de Breve vos mandámos dadas aos 30 de Mayo proximo passado deste presente anno; para que trabalhasseis com muito cuidado, a que nesta parte, nem carecessem do desejado alivio as affliçoens do nosso cuidado Apostolico, nem faltasse o remedio saudavel para se extinguir a laxidaõ de tam sagrado jejum. E porque lembrados da paternal caridade Pontificia, que sabe relevar a fragilidade dos fracos, e enfermar com os enfermos; assim como então julgamos se devia dispensar no jejum ,com Apostolica benignidade, havendo causa legitima, ou gravissima, e urgente necessidade; assim tambem entre as mais causas ordenámos, que se não havia de comer mais, que huma só vez no dia, e que de nenhuma sorte se usasse de manjares prohibidos juntamente com os não phohibidos. Consta-nos porem houve alguns, que tirando deste nosso Breve illaçoens conformes á inclinação humana, e dignas só de homens aversos á penitencia Christaã, se persuadíraó a si, e aos mais, que no dicto Breve só se prohibia mais de huma comida, ou mistura de manjares prohibidos com os licitos, quando se concedia dispensa para comer carne a alguma multidão de gente sem differença de pessoas por causa, e necessidade urgente; mas naõ, quando do conselho de hum, e outro medico se dispensava por legitima causa com cada hum em particular. Para arrancar pois totalmente dos animos de todos esta persuasão tam alheya da nossa tençaõ pelo thehor das presentes letras declaramos, e mandamos, que quando na Quaresma, mais temporas do anno e dias, em que se prohibe comer carne, óvos e lacticinios, se dispensa com quaesquer pessoas por qualquer occasiaõ; ou seja com muitos sem differença havendo urgente, e gravissima causa; ou seja com cada hum em particular havendo causa legitima, e com conselho de hum, e outro medico, todos sem excepçaõ alguma de pessoa, devem observar o naõ comer mais de huma só vez no dia, e naõ devem usar misturadamente dos manjares prohibidos juntamente com os naõ prohibidos; com tanta porèm, que naã haa alguma causa de doença certa, e perigosa, que necessariamente peça o contrario; da mesma sorte, que o mandámos, e declarámos expressamente, quando nos Breves particulares, que concedêmos a cada hum dos Fieis Christãos de hum, e outro sexo, lhe damos licença para comer manjares prohibidos no tempo da sagrada Quaresma, e outros de jejum por causa das enfermidades corporaes, que padecem. Pelo q Irmãos nossos, rogamos, e pedimos muito em o Senhor a todos, que amoestando os póvos, de que tendes cuidado, a que appliquem com toda a diligencia o remedio do santissimò jejum, tam opportuno, para sarar as chagas, com que cada hum se acha ferido por enfermidade, e fraqueza humana; com todo o cuidado paternalmente lhes advirtais, que este ponto da observancia do jejum para purificar as almas, e corpos, naõ he cousa de pouco peso, mas muito grave, e importante. Excitai pois em todos a esperança dos premios celestiaes, e que para estes se conseguirem, naõ saõ condignas as penalidades desta vida: antes hum leve, e momentaneo incómodo, não já de tribulaçaõ, mas de huma leve abstinencia alcança no céo hum grande peso de gloria. Os que contendem na luta, de tudo se despem para receberem huma corôa corruptivel por premio; envergonhem-se pois os soldados da milicia Christaã de derem tam fracos, e delicados, que fujam da com- 


\section{O. Marquês de Pombal}

panhia da Cruz de Christo, que manda esperar huma corôa incorruptivel, aos que legitimamente pelejaõ. Em signal, e penhor desta coroa vos damos com muito amor, Irmãos nossos, a benção Apostolica, que dareis tambem em nosso nome a todos vossos póvos. Queremos porèm, que aos transumptos, ou traslados das presentes letras, ainda impressos, assignados por algum Notario publico, e sellados com o sello de alguma pessoa constituida em dignidade Ecclesiastica, se dê em toda a parte o mesmo credito, que ás presentes se daria, se se exhibissem, e mostrassem. Dado em Roma em Sancta Maria Mayor, de baixo do annel do Pescador, aos vinte e dous do mez de Agosto de mil setteccentos, e quarenta e hum annos, no anno primeiro do nosso Pontificado.

\section{Cardial Passionei}

Assim pois com a mesma intençaõ tornamos a recommendar a nossos subditos, e lhes encarregamos suas consciencias, para que observem inteiramente os sobredictos Decretos de Sua Sanctidade, evitando no jejum os excessos, e abusos, que condemnaó os Auctores de melhor nota, e reprova a practica das pessoas pias, e tementes a Deos, conformando-se em tudo com os dictames Apostolicos. E para que chegue á noticia de todos, será esta publicada pelos Reverendos Parochos deste nosso Bispado, á estaçaô da Missa Conventual em tres dias Sanctos, e na Dominica da Quinquagesima em todos os annos, para o que se trasladará no livro das Pastoraes, e depois se fixará esta nas portas das Igrejas, e ultimamente passaraó os mesmos Reverendos Parochos certidoens juradas de haverem cumprido esta diligencia. Dada em Coimbra sob nosso signal, e sello de nossas Armas aos 11. de Janeiro de 1742.

\section{Miguel Bispo Conde}

\section{PASTORAL DE 22 DE FEVEREIRO DE 1746 (SOBRE O LAUSPERENE)}

J. M. J.

DOM MIGUEL DA ANNUNCIAÇAO, CONEGO REGULAR DE SANTO AGOSTINHO DA CONGREGAÇÃO reformada de Santa Cruz, por mercè de Deos, e da Santa Sé Apostolica Bispo de Coimbra, Governador, e Administrador do Bispado de Leyria por especial concessaõ de Sua Santidade, Conde de Arganil, Senhor de Cója, do Conselho de sua Magestade, \& $c$.

AOS NOSSOS CARISSIMOS IRMAXOS, E MUITO AMADOS FILHOS DESTE NOSSO BISPADO, Saude, e paz em o Senhor.

O Insaciavel desejo, e paternal amor, com que procuramos enriquecer de bens espirituaes a todos os nossos subditos, conduzio a nossa deligencia ao inexhaurivel thesouro da Igreja, do qual alcançámos num Indulto Apostolico com faculdades de instituir, e continuar por espaço de sete annos o Lausperenne para reverencia, e culto do Senhor Sacramentado: e sendo todo o tempo bem ajustado para este piedoso exercicio, nos pareceo ser mais proprio, e acceptavel este da Sagrada Quaresma, assim porque nesta devem os fieis exercitar-se com mais 


\section{D. : Miguel da Anunciação}

fervor nas obras de piedade, e devoçaõ; como taõbem, porque todos os mysterios da Sacratissima Payxão do nosso Redemptor, que a Igreja representa divididos aos olhos dos seos filhos, se achaõ recopilados, como em compendio, no Santissimo Sacramento, que he da mesma Payxaõ memorial perenne. Frequentai pois cotidianamente (ó filhos carrissimos) este convite soberano, e celestial: e nelle achareis, com mayor doçura, e suavidade do gosto do que experimentavaõ os Israelitas no seu Manná, exposto para continua refeyçaõ de vossas almas. O mesmo paõ dos Anjos, o qual, para ser tambem paõ nosso cotidiano, desceo do Ceo, e dá na sua communicação, aos que o recebem dignavel bem da graça, conseguiráó todos os fieis de hum, \& outro sexo, os quaes verdadeiramente contritos, e confessados sacramentalmente dos seos peccados, receberem o Sãtissimo Säcramento da Eucharistia, e devotamente vizitarem cada hua das Igrejas, em que estiver o Lausperenne, Indulgencia plenaria, e remissaõ de todos os pecados, assistindo por algum espaço de tempo com piedade, e devoção ao Senhor Sacramenpela paz, e concordia entre os Principes Christaõs, extirpaçaõ das heresias, cõservaçaõ do nosso Santisso Padre; vida, e saude do nosso $\mathrm{Au}$ gústissimo Monarca, e da mais Familia Real, e por Nos, que fomos vosso Pastor, e Pay porque nesta forma concede S. Sãtidade esta graça no Breve Apostolico, cujo theor he o seguinte:

\section{BENEDICTUS PAPA XIV.}

Ulviversis Christi fidelibus praesentes litteras inspecturis, salutem, \& Apostolicam benedictionem. Ad augendam fidelium religionem, \& animarum salutem coelestibus Ecclesiae thesauris pia charitate omnibus utriusque sexûs Christi fidelibus, verè poenitentibus, \& confessis, ac sacra Cõmunione resectis, qui orationi quadraginta horarum continuarum (non autem, nisi noctis tempore interpolatarum) de licentia Ordinarii, in Ecclesiis Civitatis Collimbriensis per eumdem Ordinarium specificandis, semel in anno tantùm instituendarum, per aliquod temporis spatium devotè interfuerint, \& ibi pro Christianorum Principum concordia, haeresum extirpatione, ac Sanctae matris Ecclesiae exaltatione, pias ad Deum preces essuderint, plenariam omnium peccatorum fuorum Indulgentiam, \& remissionem misericorditer in Deo concedimus: Praesentibus ad septennium tantum valituris. Volumus autem, ut si aliàs Christi fidelibus in quocumque alio anni die praemissa in dictis Ecclesiis peragenda aliqua alia indulgentia similis perpetuò, vel ad tempus nondum elapsum duratura, concessa fuerit, vel si pro imtratione, praesentatione, admissione, seu publicatione praesentium aliquid, vel minimum detur, aut sponte oblatum recipiatur, praesentes nullae sint. Datum Romae apud Sanctã Mariam Maiorem sub annulo Piscatoris, die trigesima Augusti millesimo, septengintesimo, quadragesimo primo, Pontificatûs nostri anno secundo. D. Cardinalis Passioneus. Gratis pro Deo, \& scriptura.

Aplicay pois (ó filhos) as mais efficazes, e fervorosas disposiçoeñs, e a medida destas alcançareis o grãde bem. para o qual Deos vos convida taõ liberalmente. Sede fieis na gratificaçaõ deste grande beneficio, e naõ o desmereçais por indignos, e negligentes; procurai com santa emulação exercitar o officio, e ministerio dos Anjos nas continuas assistencias, cultos, e adorações de Deos Nosso Senhor Sacramentado, e assim merecereis a felicidade eterna, e muytas prosperidades temporais.

As Igrejas, que determinamos na forma da Faculdade Apostolica assim na nossa jurisdiçaô, como dos Regulares, de consentimento 


\section{O Marquês de Pombal}

dos Muytos Reverendos Prelados locais, para a Solemnidade do Lausperenne, vaõ ordenadas na serie abaixo escripta, e a mesma solemnidade se continuará em todos os dias da Quaresma sem mais interrupçaó de tempo, que o das noite. Ultimamente concedemos a todos os nossos subditos, que se dispozerem, e exercitarem na forma sobredita, quarenta dias de verdadeyra Indulgencia, e a nossa bençaõ Pastoral. Dado em Coimbra no Paço Episcopal aos 22. de Fevereyro de 1746.

Dom Miguel Bispo Conde.

\section{PAUTA DAS IGREJAS, EM QUE SE HA DE CELEBRAR O LAUSPERENNE}

\section{FEVEREIRO}

$\mathrm{Na}$ Sé Cathedral

$\mathrm{Na}$ Igreja de S. Justá

23. e 24

$\mathrm{Na}$ Igreja de S. Joaó de Almedina

25. e 26

27. e 28

\section{MARÇO}

Na Igreja do Collegio de S. Bernardo.

1. e 2 .

$\mathrm{Na}$ Igreja de $\mathbf{S}$. Tiago.

Na Igreja do Collegio da Trindade.

$\mathrm{Na}$ Igreja do Collegio de S. Thomaz.

$\mathrm{Na}$ Igreja de $\mathrm{S}$. Pedro.

Na Igreja do Real Collegio da Cõp. de Jesus.

3. e 4 .

5. e 6 .

7. $\mathrm{e} 8$.

$\mathrm{Na}$ Igreja de S. Bartholomeo.

9. e 10 .

$\mathrm{Na}$ Igreja do Real Mosteiro de S. Cruz.

$\mathrm{Na}$ Igreja do Collegio de S. Joseph.

11. e 12 .

13. e 14 .

$\mathrm{Na}$ Igreja do Collegio de S. Bento.

$\mathrm{Na}$ Igreja de $\mathrm{S}$. Christovaõ.

Na Igreja do Collegio da Graça.

$\mathrm{Na}$ Igreja do Collegio de S. Jeronymo.

$\mathrm{Na}$ Igreja do Convento de S. Anna.

Na Igrea do Convento de S. Thereza.

15. 16. e 17 .

18. e 19 .

20. e 21 .

22. e 23 .

24. e 25 .

26. e 27.

28. e 29 .

30. e 31 .

PASTORAL DE 6 DE ABRIL DE 1747 (SOBRE A ORAÇÃO MENTAL)

J. M. J.

Dom Miguel da Annunciaçção, Conego Regular de Santo Agostinho da Congregação Reformada de Santa Cruz, por Mercé de Deos, e da Santa Sé Apostolica Bispo de Coimbra, Conde de Arganil, Senhor de Côja, do Conselho de Sua Magestade, etc.

\section{Ao Nosso Amado Clero, e Povo Saude, e benção no Senhor.}

Fazemos saber, q o SS. Padre Benedicto XIV, estimulado do zelo verdadeiramente Apostolico da mayor honra, e gloria de Deos, e proveito das almas remidas com o preciozissimo Sangue do cordeiro immaculado JESU Christo, por hum Breve expedido aos dezaseis de 


\section{Miguel da Anunciação}

Dezembro do anno proximo passado, dirigido a todos os Prelados da Igr." Santa, inscrito nesta nossa Pastoral, exhorta os Fieis ao consorcio, e trato familiar com D.' por Meyo da Oração Mental, e á q frequentem este exercicio Santo, não só nas cazas particulares diante de alguma imagem Sagrada, mas principalm. $t^{\circ}$ nas Sés Cathedraes, e mais Igr.as e Capellas publicas, assim das cid..$^{\text {es }}$, como das Villas, lugares, e Aldeas do mundo Christão, aonde ao som do sino se deve ajuntar o povo, p.a q concorrendo m.tos no nome do Senhor, esteja este no meyo delles, e a concordia, a conspiração, o vinculo do amor, o clamor da claridade faça as oraççóes, ainda dos mais tibios, fervorosas, e efficazes no acatamento de sua Divina Magestade, e como as indulgencias são o atractivo da devoção, e piedade Christã, se vala o SS. Padre deste meyo p. persuadir mais efficazm. $t^{\circ}$ e pratica, e frequencia da Oração Mental, como se manifesta no refirido Breve, q he do theor seguinte.

O que traduzido no nosso idioma he como se segue.

Aos Veneraveis Irmãos, Patriarcas, Primazes, Metropolitanos, Arcebispos, Bispos,

e a todos os Prelados Ordinarios dos Lugares, que gozão da graça, e communicação da Sé Apostolica.

\section{Benedicto Papa XIV.}

Veneraveis Irmãos; Saude, e Benção Apostolica. Assim como para os homens divertidos, e apartados do comercio, e trato familiar com Deos participarem as Divinas Luzes, procurarem a Salvação eterna, e como em hum corpo bem ordenado se chegarem todos à prezença de Deos, nada há mais opportuno saudavel, e necessario, do q a Oração, a qual he como huma elevação da alma das cousas terrenas p.a as celestiais, indagação das cousas Supiriores, dezejo do invesivel, união com o Espirito Santo, e conversação com Deos; assim p.a que o Mundo todo senão destrua com huma total assolação, pela razão de $\mathrm{q}$ ninguem attentam. $\mathrm{t}^{\circ}$ medite dentro do seu coração, todos, e cada hum em todo o lugar, e em todo o tempo hão de ser admoestados com saudaveis preceitos, de q convem sempre orar, e nunca desistir; $p .^{a} \mathrm{q}$ em toda a oraçam, e petição com rendim.t t $^{\circ}$ de graças, manifestas as nossas Supplicas diante de D. o mesmo Senhor, q he liberal p.a todos os q o invocão, nem de si a parte as nossas petições, nem de nós as suas mizericordias.

Por esta razão os Pontifices Romanos Nossos Predecessores, dirigidos por Divina instrucção, p. ${ }^{a}$ excitar os fieis Christãos a buscar com diligencia, e frequentar sem interrupção o exercicio da oração, ou Vocal, ou, como dizem, Mental, cuidarão muito assim em inflamallos com exhortações, como tambem em os althahir com os thezouros dos dons Celestiaes, cuja distribuição lhe comettira o Altissimo. Portanto concederão Liberalm.t t $^{\circ}$ indulgencias, remissões de pecados, e relaxações das penitencias, $q$ lhe fossem impostas, e de qualquer modo devidas áquelles, $q$ ou rezassem vocalm.t $t^{\circ}$ ou todos os dias meditassem por algum espaço de tempo na Ley do Senhor. Movidos pois Nós ditão Louvaveis exemplos dos nossos mesmos Predecessores, não sóm.t $t^{\bullet}$ confirmamos do mesmo modo, e forma, e q.l he necessario de novo concedimos, pelo theor das prezentes, Aucthoritate Apostolica, todas, e quaesq. ${ }^{r}$ idulgencias, remissoens, de peccados, e relaxaçoens de penitencias athé agora de qualquer modo, ou por tempo determinado, ou p.a sempre concedidas pelos mesmos Predecessores/contando, q nunca fossem revogadas/aos q rezarem quaisq. ${ }^{\mathrm{r}}$ oraçoens vocais, ou de qualq. ${ }^{\mathrm{r}}$ oraçoens 


\section{O Marquês de Pombal}

vocais, ou de qualq..$^{r}$ modo orarem ,mas tambem alem destas concedemos, outras principalm. $t^{\circ}$ àquelles, $q$ se applicarem ao exercico da Oração Mental, ou meditação, como abaixo se declara.

Primeiramente a todos, e a cada hum dos $q$ assim nas Igrejas, como em outro qualq. ${ }^{\mathrm{r}}$ lugar publico, ou particularmente encinarem a quaesquer homens, q ainda, o não sabem, a orar de q. $.^{\mathrm{a}} \mathrm{lq} .^{\mathrm{r}}$ modo, conditar, caso, q assistirem a esta instrucção deorar, e meditar, como assima se declara por cada ves $q$ isto fizerem, com tanto que estejão verdadeiram. t $^{\bullet}$ arrependidos, e tenhão recebido a Sagrada Comunhão, relaxamos na forma costumada da Igr.a sette annos, e outras tantas quarentenas das penitencias, $q$ lhes fossem impostas, ou de outro qualq. ${ }^{r}$ modo devidas. Aquelles porem, assim os, q ensinarem, como os, que aprenderem, q continuarem com frequencia o sobredito, e do mesmo modo verdadeiram $t^{\circ}$ contritos, e tendo comungado, rogarem a Deos pela concordia dos Principes Christãos, extirpação das herezias, e exaltação da Santa Madre Igreja, concedemos mizericordiozamente em o Senhor huma ves no Mes a arbitrio, e cômodidade de cada hum, indulgencia plenaria, e remissão de todos os seus peccados, a qual indulgencia possão applicar por modo de suffragio pellas almas dos Fieis, que passaram desta vida em graça, e a mitade de Deos.

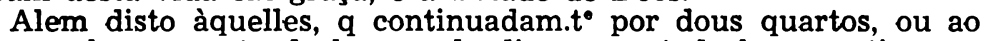
menos por hum quarto de hora cada dia, e por todo hu mes tiverem oração Mental, e verdadeiramente arrependidos, e confessados receberem o Santissimo Sacramento da Eucharistia, e juntam. $t^{\circ}$ rogarem a Deos pela concordia dos Principes Christãos, extirpação das heresias, e exaltação da Santa Madre Igr. com o mesmo theor, e authoridade concedemos mizericordiozam. $t^{\circ}$ em o Senhor huma ves por cada mes indulgencia plenaria, e remissão de todos os seus peccados, a qual indulgencia possão applicar por mode de Suffragio às mesmas almas dos fieis, q se apartarão desta vida, unidas a Deos pella claridade.

Mas ainda conforme o preceito Divino de Nosso Senhor JESU Christo, convem, que cada hum qd..$^{\circ}$ ha de orar para q não seja visto dos homens, como procurão os Hypocritas, se recolha no interior de sua caza, e occultam. $t^{\circ}$ retirado faça oração a seu Pay Celestial: Comtudo, como o mesmo Senhor disse, $q$ aonde se auntão em seu nome dous, ou tres, ahi no meyo delles assiste; e como ensina São João Chrisostomo, q na oração de muitos ha mais alguma couza, q vem a ser a concordia, conspiração, e vinculo do amor, e o clamor da claridade, com huma feliz sociedade, pela qual as Oraçoens ainda tibias, juntam.t ${ }^{\circ}$ unidas entre si, sobem ao Ceo mais efficazes: seria m.to justo, onde se podesse fazer cõmodamente que, como ouvimos praticarse em algumas, assim em todas, e cada huma das Diecezes se introduzisse este costume, a saber; q em todos os dias dado certo sinal com os sinos. ou nas Igrejas, comtanto $q$ a multidão de todo o povo possa facilm.t t $^{\circ}$ auntar-se em hu lugar, aonde tenha oração, separados os homens das mulheres, e senão siga confuzão, e desordem, ou em sua propria caza os Pays de familias no mesmo, ou em outro tempo mais opportuno juntos com toda a sua familia, orem diante de alguma imagem Sagrada.

Pela qual razão, Veneraveis Irmãos, Vos rogamos, e exhortamos em o Senhor, q mandeis a todos, e a cada hum dos Superiores, e Reytores das Igrejas, e Lugares Pios. a saber, nas cid. ${ }^{\circ}$ aos da Igreja Cathedral, e das outras Igr.as principaes, e nas outras terras aos das Igrejas Parochiais, que dado o Signal com o sino, o qual se ha de dar, e determinar naquelles dias, e horas, q em o Senhor vos parecer mais opportuno, ensinem, ou fação ensinar por outros intelligentes o exercicio da oração Mental a todos os Fieis Christãos entregues ao seu cui- 


\section{Miguel da Anunciação}

dado, q a este fim concorrerem, e os excitem a frequentar a mesma oração, e lhes proponhão a necessidade, e utilid. ${ }^{\circ}$ della, e lhes expliquem os thesouros de indulgencias, q por benignid. Apostolica lhes concedemos, e procurem com toda a efficacia inflamallos a lucrar esses thezouros com aquella piedade, e reverencia, q convem; e da mesma sorte, se cõmodamente puder ser, como assima declaramos, fação, e procurem q se appliquem à Oração Mental, e se exercitem nella em cõmum pratica, como se dis. Tendo seu vigor as prezentes Letras perpetuamente no tempo futuro; e queremos q às Copias, ou transumpttos das mesmas prezentes Letras ainda impressos, sobscriptos por mão de algum Notario publico, e sellados com o sello de alguma pessoa constituida em dignidade Ecc. ${ }^{2}$ se dé inteiram.t ${ }^{\circ}$ a mesma fé, $q$ se daria às mesmas prezentes, se fossem exhibidas, ou mostradas. Entretanto, Veneraveis Irmãos, mizericordiozam. $t^{*}$ vos concedemos a Benção Apostolica. Dado em Roma em Santa Maria Maior SubAnnulo Piscatoris aos 16. de Dezembro de 1746. anno Sexto do nosso Pontificado.

\section{Caietano Amati.}

Pelo q vos exhortamos, e rogamos, Irmãos, filhos clarissimos, a q. ${ }^{m}$ amamos muito nas entranhas de JESU Christo, que não sóm.t ${ }^{\dagger}$ com animo prompto, e alegre vos conformeis com as Santissimas intençoens do nosso Supremo Pastor, mas tambem, q abraceis os saudaveis conselhos, e ditames, vos propoem neste Breve, q respira devoção, e piedade com o mayor fervor dos vossos espiritos. Mandamos aos Reverendos Parochos desta cidade, e de toda a nossa Diecesi, $\mathrm{q}$ agora ainda com mayor exação, e cuidado observem o Capitulo 13. da nossa Pastoral de quatorze de Outubro de 1741, em q, determinamos o tempo, os lugares, o modo de practicar o Santo exercicio da of ação Mental, ao qual farão os mesmos Revrendos Parochos chamar o povo com o toque dos sinos por espaço conveniente.

Recomendamos m.to ao nosso amado povo, $q$ em ouvindo o dito sinal concorra com huma emulação Santa às Igreas, q são cazas de oração, apostrar-se na prezença do Senhor, que gosta de estar com os filhos dos homens, cheio de confiança, de q hade alcançar da sua grandeza, e mizericordia todas as mercés, e graças que pedir em seu nome, como nos promette no seu Evangelho. $\mathbf{E}$ advertimos ao clero a grande obrigação, q tem, de animar o Povo a huma acção tão pia, e louvovel com o exemplo.

Mandamos tambem aos Reverendos Padres ensinem respectivamente aos seus freguezes o methodo de praticar com fruto espiritual o dito exercicio da oração Mental com tanta distinção, e clareza, q possão ser entendidos, ainda dos mais rudes, e simplices, com os quaes se digna conversar o Senhor para q senão queixem estes, de q os seus Pastores não lhe souberão repartir o pão de doutrina, e q necissitando de leite, lhe derão a comer manjares solidos, e improporcionados à sua capacidade.

Ordenamos aos Reverendos Sacerdotes, cooperadores da nossa Ordem, e aos mais clerigos de Ordens Sacras empenhem o seu zelo no ensino do mesmo methodo. $\mathrm{E}$ admoestamos finalmente a todos os nossos Subditos se appliquem a aprendello com grande ancia do seu aproveitam. t $^{\circ}$ espiritual, para q se fação cada ves mais dignos da Benção do Senhor, da de sua Purissima May Maria Santissima Senhora nossa, da de seu Castissimo Espozo S. Jozé, Augustos Protectores do nosso Bispado, e da nossa, q com Paternal amor lançamos a todo o nosso Rebanho. 


\section{O Marquês de Pombal}

E p." que esta nossa Pastoral venha à notícia de nossos Subditos, mandamos a cada hum dos Reverendos Parochos deste Bispado a publiquem nos tres primeiros dias Santos depois da sua entrega, e fação trasladar nos Livros destinados, p." este effeito de boa Letra, e o nosso Reverendo Escrivão da Camera a registe, e lança tambem nos Livros das Pastoraes, como he estilo. Dada em Coimbra sob nosso sinal, e sello de nossas Armas, aos seis do mes de Abril de 1747. annos. E eu, Leandro Vasques de Miranda Escrivão da Camera a Sobscrevi.

\section{Miguel Bispo Conde} Mental.

Pastoral com Breve inserto de Sua Santidade sobre a Oração Para V. Excellencia ver, e assinar.

A.U.C., Livro das Pastoraes da Igreja de S. Tiago, fls. 90-95 v. ${ }^{\circ}$

\section{ABRIL}

Na Igreja do Colleg. de S. Pedro da Orde 3.

1. e 2.

Na Igreja do Colleg. dos Carmelitas Calçados.

3. e 4.

Na Igreja de S. Caza da Mizericordia.

5. e 6 .

Conego Regular de S. Agostinho da Congregaçaõ de S. Cruz de Coimbra por mercè de Deos, e da S. Sé Apostolica Bispo de Coimbra, Conde de Arganil, Senhor de Coja, e do Conselho de Suà Magestade Fidelissima, \& $c$.

Ao nosso amado Clero, e Povo, Saude, e Bençaõ no Senhor

ASSIM como naõ ha cuidado que nos seja taó familiar, e que tanto occupe o nosso coraçaõ, como solicitador, e promover os espirituaes adiantamentos do rebanho que o Senhor nos ha confiado; tambem he incomparavel o Jubilo que concebemos, quando a Providencia nos ministra occasiões favoraveis de soccorermos as nossas Ovelhas, e de lhes dispensarmos mais abundantes as graças, do q cabem ainda na extensaõ do nosso Caracter, mas $q$ naõ excedem os dilatados limites do nosso Pastoral, e Paternal affecto. A favor deste, e do bem commum, q anciosamente dezejamos, veyo a nova graça com que a beneficentimssia profusaõ do Sumo Pastor o Santissimo P. Clemente XIII que venturosamente veneramos na Cadeira de S. Pedro, espalha por todo o Mundo Christaõ os inexhauriveis thesouros da Igreja, nos felicissimos exordios de seu Pontificado, como nos certifica pela Bulla do Jubileo Plenissimo, que se dignou conceder-nos: a qual fielmente traduzida, e copiada, he da fórma que se segue

Jubileo Geral para impetrar o Divino auxilio do nosso Pontificado, para o saudavel regimen da S. Igreja Catholica. 


\section{Miguel da Anunciação}

\section{CLEMENTE PAPA XIII.}

Apostolica.

A todos os Fieis, que estas nossas Letras virem, saude e bençaõ TEMOS chegado ao alto mar, e para que com a luta dos contrarios ventos naõ fiquemos submergidos com suas ondas, clamamos a Deos com incessantes gemidos, para que neste Apostolico, e gravissimo ministerio, taõ desigual ás nossas forças, nos conceda copioso auxilio, e socorro de sua efficacissima graça, e benignissimamente receba neste dia de tribulação as nossas continuas supplicas. Pois quem interior, e exteriormente naõ tremeria? Quem naõ se penetraria de grandissimo temor? Quem de todo naõ desmayaria de tristeza, pondo diante dos olhos, e contemplando attentamente o mestissimo aspecto da Religião Catholica, e desta Sé Apostolica? Quem finalmente naõ derramaria copiosissimas lagrimas á vista de taô horrorosas feridas, feitas á fé, á disciplina, e aos nossos direitos? Mas naõ he necessario referir todos os males, e passar em silencio os remedios opportunos, com que possamos acodir a tantos damnos. Naõ ha doença taõ grande, taố dilatada, taó perigosa, que naõ se possa curar, ou á qual certamente o Omnipotente Deos, cuja misericordia sobreexalta o juizo, naõ possa socorrer pela sua ineffavel Clemencia. Cheguemos pois com confiança ao seu Throno em tempo opportuno, porque as nossas armas, com que podemos forte, e constantemente resistir a tantos males, saó as orações, os jejuns, e as esmolas; sabemos, que se permanecer-mos nelle, e as suas palavras em nós, pediremos o que quizermos, e se nos concederá. Convertamo-nos pois a Deos de todo o nosso coraçaõ em jejum, em lagrimas, em pranto, nem viremos o nosso rosto de algum pobre; porque assim nem o Senhor virará de nós a sua Divina face. $\mathbf{E}$ para que tudo isto se faça com mayor fervor do espirito, e mayor fruto, seguindo $o$ antigo costume dos Romanos Pontifices nossos Predecessores, havemos determinado nos dias proximos, em que a Igreja Catholica observa o jejum das quatro temporas, abrir os thesouros das Celestiaes graças, cuja díspensaçaõ nos está commettida para implorar de nosso Senhor o feliz principio do nosso Pontificado. Pelo que fundados na misericordia de Deos todo Poderoso, e na auctoridade dos Bemaventurados Apostolos S. Pedro, e S. Paulo, com aquelle poder de ligar, e absolver, que o Senhor tem meritos nossos nos concedeo a todos, e cada hum dos Fieis Catholicos de hum, e outro sexo, moradores nesta nossa Cidade de Roma, que devotamente assistiram á Procissaõ solemne, que com a benção do Senhor havemos fazer na Dominga decima oitava depois de Pentecoste, aos dezassete do corrente mez de Settembro desde a Igreja de S. Maria dos Anjos in Thermis the a Basilica de S. Maria Mayor da mesma Cidade, acompanhados dos nossos veneraveis Irmaõs Cardiaes da S. Igreja Romana, e tambem dos $\mathrm{Pa}-$ triarchas, Arcebispos, e Bíspos, que se acharem na Curia Romana, e dos Embaixadores e Ministros dos Reis, e Principes Christaõs assistenaes nesta Corte, tambem dos Prelados, e Officiaes da mesma Curia, e de todo o Clero, e povo, ou dentro do espaço da mesma semana, ou da proximidade seguinte visitarem ao menos huma vez as Igrejas, ou Basilicas de S. João de Latraó do Principe dos Apostolos, e S. Maria Mayor acima referida, ou alguma dellas sómente, e nella fizerem por algum tempo oraçãão a Deos, e jejuarem a Quarta, Sexta, e Sabado, de huma das sobreditas semanas, e depois de confessados receberem com a devida reverencia o Santissmo Sacramento da Eucharistia na Dominga immediatamente seguinte, ou em outro dia dentro da mesma semana, e soccorrerem aos pobres com alguma esmola, como a cada hum inspirar a sua devoçaõ, e aos outros que moraõ em qualquer outro lugar 
fóra da dita Cidade, e ao menos huma vez visitarem as Igrejas, que depois da noticia destas nossas Letras para este fim destinarem os Bispos, ou os seus Provizores, ou Vigarios Geraes, ou por sua ordem, e em falta delles os que exercitarem Cura de Almas, ou visitarem ao menos alguma das ditas Igrejas dentro do espaço tambem das duas seguintes semanas, depois que os Bispos, ou seus Provizores, os Vigarios Geraes, ou outros, como fica dito, pelo Theor destas concedemos Indulgencia Plenaria, e amplissima remissaõ de todos os seus peccados, como se costumou conceder no Anno do Jubileo, aos q visitaõ certas Igrejas dentro e fóra da referida Cidade de Roma. Mas os que actualmente se acharem fazendo viagem pelo mar, ou jornada por terra, poderáó gozar do mesmo indulto, e alcançarem a dita Indulgencia Plenaria depois que se recolherem a suas cazas, cumprindo tudo o referido, e visitando a Igreja Cathedral, ou a Parochial da terra, em que tiverem o seu domicilio. Porèm aos Regulares de hum e outro sexo, ainda aos que vivem em perpetua clauzura, como tambem a outros quesquer assim leigos, como Ecclesiasticos Seculares, ou Regulares, aos que estaõ encarcerados, ou captivos, ou aos que por alguma enfermidade corporal, ou outro qualquer embaraço naõ poderem executar em tudo, ou em parte as couzas referidas, permittimos, e damos faculdade para que o Confessor approvado pelo Ordinario antes, ou depois da publicaçaõ destas, lhas possa commutar em outras obras pias, ou prorogá-las para outro proximo tempo, e impôr-lhes aquellas couzas, que os mesmos penitentes poderem cumprir. Alem disto a todos, e a cada Fiel Christaõ de hum e outro sexo assim Leigos, como Ecclesiasticos Seculares, e Regulares de qualquer Ordem, Congregaçaõ, e Instituto, moradores na dita Cidade de Roma, ou fóra della em qualquer terra como fica dito, damos faculdade, e licença de elegerem pra este fim hum Sacerdote Confessor Secular, ou Religiozo de qualquer Ordem, e Instituto sendo approvado pelos Ordinarios Locaes, como acima se dice, e que este no foro da consciencia os possa livrar, e absolver por esta vez sómente de toda a excommunhaõ, suspensaô, e outras sentenças, e Censuras Ecclesiasticas por qualquer cauza fulminadas à jure, vel ab homine, e assim mesmo de todos os peccados, excessos, crimes, e delictos por mais graves, e enormes que sejaó, ou de qualquer modo reservados aos Ordinarios, ou a Nós, e a esta Sé Apostolica, como tambem dos conteûdos na Bulla da Cêa do Senhor, e por outros quaesquer nossas Constituições, ou dos Romanos Pontifices nossos Predecessores, cujos theores queremos se hajaó por expressos nas prezentes; item que lhes possa commutar quaesquer votos (exceptos os de Religiaõ, e de Castidade) em outras pias, e santas obras, dando porèm o Confessor em todos os cazos referidos a saudavel penitencia, e outras o seu arbitrio conducentes a cada hum dos penitentes. Pelo que pelo theor destas mandamos em virtude de Santa Obediencia a todos, e cada hum dos Veneraveis Irmaõs Patrriachas, Arcebispos, Bispos, e outros Prelados das Igrejas, aos Ordinarios Locaes, e a seus Provizores, e Vigarios Geraes, ou em falta destes aos que exercitaõ Cura de Almas, que tendo recebido a copia, ou traslado tambem impresso das prezentes Letras, sem demora tardança, ou impedimento algum, o publiquem, e façaõ publicar logo pelas suas Igrejas, Deoceses, Provinciais, Cidades, Villas, Aldeas, e Lugares, e destinem a Igreja ou Igrejas, que se haõ de vizitar. Naõ he porèm a nossa intençaõ dispensar por meyo destas em alguma irregularidade publica, ou occulta, nota, defeito, incapacidade, ou inhabilidade, de qualquer modo contraída, nem dar faculdade alguma para dispensar, ou habilitar, e restituir ao antigo estado, ainda que seja no foro da consciencia; nem que estas mesmas letras de algum modo possaõ, nem devaõ utilizar áquelles, que de prezente se acharem 


\section{Miguel da Anunciação}

ligados com alguma excõmunhaõ, suspensaõ, e interdito por nós e pela Sé Apostolica fulminadas, ou por algum Prelado, e Juiz Ecclesiastico, ou que publicamente tenhaõ sido declarados, e denunciados por incursos em quaesquer outras sentenças, e censuras, se no espaço das ditas duas semanas naõ derem satisfaçaõ ás partes, ou com ellas se compozerem. Naõ obstante as Constituições, e Ordenações Apostolicas, principalmente aquellas, em que a licença de absolver de certos cazos nellas expressos de tal sorte fica rezervada ao Pontifice Romano neste tempo rezidente, que ninguem se possa aproveitar de concessões de indulgencias, e faculdades similhantes, ou dissimilhantes, sem se fazer mençaõ expressa, ou especial derogação dellas; naõ obstante tambem a nossa Regra de naõ conceder indulgencias ad instalar, nem as Leys, e costumes de quaesquer Ordens, e Congregações, ou Institutos roborados com juramento, confirmaçaõ Apostolica, ou outra firmeza, nem finalmente os Privilegios, Indultos, e Letras Apostolicas de qualquer modo concedidos, e approvados, e de novo estabelecidos a favor das mesmas Ordens, Congregações, e Institutos, e seus individuos. Todos os quaes, e cada hum delles derogamos, como tambem outros quaesquer contrarios a este, ainda q delles e seus completos theores se devesse fazer para este fim especial mençaõ, ou outra qualquer declaração especifica, expressa, e individual, e naõ por clauzulas geraes q importassem o mesmo, ou fosse necessario uzar de alguma outra fórma exquizita para derogação dos mesmos, tendo pelas prezentes Letras por sufficientemente expressos os seus theores, etc.

\section{PASTORAL DE 8 DE NOVEMBRO DE 1768 (SOBRE LIVROS PROI- BIDOS)}

D. Miguel da Annunciação, cónego regular de Santo Agostinho da congregação reformada de Santa Cruz, e por mercê de Deus e da Santa Sé Apostólica Bispo de Coimbra, Conde de Arganil, Senhor de Coja, do conselho de Sua Majestade Fidelissima etc.

Ao Nosso amado clero e povo saúde e a Nossa benção no Senhor.

Attendendo Nós á obrigação indispensavel que temos, de guardar o depósito que Sua Divina Majestade se dignou commetter-Nos; e sendo informados, não sem grande afflicção do Nosso espirito, que o homem inimigo não cessa de sobresemear a sizánia dos escriptos perversos e escandalosos entre o bom trigo dos dogmas da fé, das máximas do Evangelho e da moral de Jesus Christo, nos pareceu que deviamos oppôr-nos como muro a esta torrente inundante de doutrinas várias e peregrinas, que se teem derramado nesta cidade e tememos passem a toda a diocese, com prejuizo immenso das almas e das consciéncias. E considerando Nós, que estas obras das trevas não sòmente conteem muitas proposições contrárias á pureza da fé e á santidade da lei; mas que são inteiramente corruptas e corruptoras da religido christã, da disciplina e da piedade, e capazes de introduzir a abominação no logar santo, que é a Igreja julgamos, irmãos e filhos carissimos, dar-vos testemunho destas obras, mas com o fim de que não contamineis os vossos corações com tão immundos escriptos; pois se o Apóstolo nos adverte que nos separemos de todo o irmão que anda desordenado e não vive conforme os dithames da pura e santa doutrina, - quanto mais devemos evitar a lição d'estes auctores, que persuadem com maior efficácia, por meio de textos artifiosamente applicados, de razões apparentes e da força ou suavidade do estylo, as abominações, os erros e as 


\section{O Marquês de Pombal}

mentiras. São, pois, os livros, que nestes últimos tempos se teem composto contra a religião revelada, contra a pureza dos costumes, contra a obediéncia devida aos soberanos, que queremos eviteis ,como peste, os seguintes:

L'Espion dans les cours des Princes chrétiens, ou Lettres et Mémoires d'un Envoyé secret de la Porte dans les cours de l'Europe;

Lettres cabalistiques;

Lettres chinoises;

Lettres juives;

Lettres sur la religion essentielle à l'homme:

Oeuvres du philosophe de Sanssouci;

Tableau du siècle;

Encyclopédie ou Dictionnaire raisonné des sciences, des arts et des métiers;

De l'Esprit

L'Espion de Thomas Kouli-Kan dans les cours de l'Europe;

Le contract social;

La philisophie de l'histoire;

Discours súr l'inéqualité des hommes, de M. Rousseau;

Dictionnaire Philosophique;

La philosophie de l'histoire;

Abrégé de l'histoire, de M. de Voltaire;

Essai sur l'histoire, do mesmo auctor;

L'Henriade, do mesmo;

Précis de l'Ecclésiaste et du Cantique;

L'Esprit, de M. Voltaire;

Le despotisme oriental;

Dupin, De antiqua Ecclesiae disciplina, Dissertationes historicae, a quem segue Justino Febrónio, De statu Ecclesiae et legitima potestate Romani Pontificis;

La Pucelle d'Orléans, de M. Voltaire;

Belisaire, par M. Marmontel, de l'Académie Française.

Vede agora e atendei, irmãos e filhos caríssimos, que o desígnio d'estes auctores parece ser de arrancar dos corações dos fieis pela raíz as regras puras dos costumes, a doutrina mais sã da lei, os dictames mais sólidos da moral, e introduzir o indifferentismo e fanatismo, capaz de fazer que muitos naufraguem na fé; de pôr em maior risco as preciosas vidas do rei e dos principes; e de alterar a boa harmonia que deve haver entre o sacerdócio e o império: - Ex sacerdotio et regno - diz Isidoro Pelusiota $\left(^{1}\right)$ - rerum administratio conflata est; ad animarum salutem. Empenhando-se estes escriptores temerários e sacrílegos em illudir os homens com vãs imagens de uma especiosa philosophia, e corromper a adolescéncia, ou menos radicada na fé, ou menos instruída na moral, ou menos firme nos caminhos do Senhor, e por consequéncia mais susceptivel das impressões do erro e do engano: de modo que estes apóstolos da mentira teem causado na cidade santa maior ruína que os gentios nos primeiros séculos e nos seguintes os hereges; sendo para a Igreja mais amarga a paz de que agora gosa do que foi a guerra que então a combatia; porque aquella guerra

(1) Lib. 3, Epist. 230. 


\section{Miguel da Anuncią̧ão}

coroava os mártyres, multiplicava os fieis e a banhava de contentamento a alegria; e esta paz representa á mesma Igreja objectos tristes em muitos dos seus filhos iniquos $\left(^{2}\right)$ e zelosos da impiedade, que por meio dos seus escriptos, como caçadores do inferno, armam laços á innocéncia e redes á piedade, e por isso parecem comprehendidos no número d'aquelles infelizes, que vendo Jeremias em espírito, disse ou gemeu $\left({ }^{2}\right)$ : Inventi sunt in populo meo impii insidiantes, quasi aucupes laqueos ponentes, et pedicas ad capiendos viros $\left({ }^{3}\right)$.

E verdade que estes falsos prophetas não lançam por terra os altares, mas impedem com as suas erradas notícias se adore o verdadeiro Deus, que quer ser adorado em espírito e verdade; não tiram a vida corporal aos fieis com ferro, mas se applicam a privar os mesmos fieis, com o veneno da sua sciencia, ou, para melhor dizermos, da sua ignoráncia, de outra vida mais nobre, que é a do espírito, alterando a sua fé, pervertendo os seus costumes, levantando nesciamente a sua soberba contra a doutrina e sciéncia de Deus; preferem o nome de philósophos ao de cristãos, atrevendo-se a tratar como superstição, esphera limitada e fraqueza de espírito a fiel observáncia da lei; e os verdadeiros christãos como insensatos, ou menos illuminados, os quaes, vendo-se combatidos sem causa, esperam debaixo das azas do Senhor até que passe a iniquidade.

Finalmente elles fingem um Deus cego, sem providéncia, sem discernimento, sem justiça na distribuição dos prémios e dos castigos, e se fabricam um Deus que põem em templos excelsos. D'este modo, depois de negarem ou pretenderem escurecer os princípios da religião revelada, ou abusando d'elles, intentam confundir a unidade do ministério sagrado, com divisōes do centro da mesma unidade; pontos de mera disciplina com verdades da fé e da moral; os direitos com puros factos, e os bem ordenados poderes do sacerdócio e do mpério com a dissimulada desordem entre ambos; e pôr artificiosamente como em parallelo as seitas mais abomináveis com a religião christã pura, santa e immaculada, como se fosse compativel e conviesse a luz com as trevas, o templo de Deus com o ídolo de Belial; mas infelizmente, porque estes auctores, víctimas dos anjos das trevas, como impugnam a verdade, perdem a paz e com as suas próprias armas se ferem sem misericórdia; porque, como já disse Lactáncio ( $\left.{ }^{*}\right)$, esta é a natureza das mentiras, que se não podem ajustar ou convir entre si - Hoc est enim mendaciorum natura, ut cohaerere non possint.

Mas porque seria inutil esta pastoral, se a não munisse a imposição das penas, que são o nervo da disciplina e a barreira da iniquidade, mandamos aos nossos súbditos no Espírito Santo, e em virtude da santa obediéncia, não leiam nem ouçam ler os livros que temos declarado nesta nossa pastoral, não tendo aliás licença legítima para ler lívros prohibidos, fugindo, como de peste, de lição tão contagiosa e nociva; e advertimos aos confessores, assim seculares, como regulares, a obrigação de suspender ou differir a absolvição no juízo sacramental aos que repugnarem obedecer á voz de Deus, intimada nesta pastoral, não querendo deixar de ler tão perniciosos escriptos, ainda mais funestos que as letras de Urias; porque se não privam da sua

(1) Noutra cópia le-se: e muitos dos seus faz iníquos. ou gemia.

(2) Variante de outra cópia: no número d'aquelles, que Jeremias em espirito disse

(3) Cap. V, v. 26.

() Lib. 5 Instit. cap. 3. 


\section{O Marquês de Pombal}

vida o corpo, privam a alma de outra incomparavelmente mais preciosa, mais nobre e mais digna.

Que tendes vós, irmãos e filhos caríssimos, que ver no caminho do Egypto, para beber a água turva? Que podeis aprender, que não seja muito melhor ignorar, d'estes doutores da iniquidade? Acaso não ha entre vós algum sábio, ou faltou em Galaad a rezina e o médico? Correi a beber na fonte, da qual mana a água da vida eterna; queremos dizer a escriptura e tradição, os Santos Padres e os concílios; e acautelai-vos d'aquellas cisternas arruinadas, para não beberdes a morte nas suas águas venenosas e corruptas.

Esta é a doutrina, irmãos e filhos caríssimos, conforme á piedade, que Nos parece propôr-vos, com o fim de não communicarmos nos peccados alheios e nos fazermos participantes das obras infructuosas das trevas pela Nossa dissimulação e pelo Nosso siléncio, no mesmo tempo que somos obrigados a não nos envergonharmos do Evangelho, e a publicar dos logares mais altos os invioláveis direitos de Deus, e a manifestar aos Nossos súbditos os laços que no campo da Igreja tem armado o nosso commum inimigo á sua innocéncia, valendo-se d'estes espiritos da maldade, dos quaes parece disse Jeremias $\left(^{1}\right)$ :- Quomodo dicitis: Sapientes nos sumus, et lex Domini nobiscum est? Vere mendacium operatus est stylus mendax scribarum - Confusi sunt sapientes... Verbum enim Domini projecerunt et sapientia nulla est in eis.

Dada no Nosso Paço Episcopal, firmada com o Nosso signal, e sellada com o sello das Nossas armas, aos 8 de novembro de 1768. E eu, o Padre Jerónimo Saraiva dos Santos, escrivão da cámara, a sobscrevi.

\section{Miguel, Bispo Conde}

\section{XIV - PARECER DA REAL MESA CENSÓRIA (23-12-1768) (1)}

Sentença da Real Meza Censoria, contra a Pastoral manuscripta e datada de 8 de Novembro proximo passado, que - Bispo de Coimbra, D. Miguel da Anunciação espalhou clandestinamente pelos parocos da sua diocese, proferida no dia 23 de Dezembro de 1768.

Lisboa, Na officina de António Rodrigues Galhardo, Impressor da Real Meza Censoria MDCCLXVIII.

Em Colleç̧ão de Leys, Decretos e Alvarás, ordens religiosas e editais, que se publicaram desde o anno de 1761 até o de 1769, Lisboa, 1776.

Manda ElRey N. Senhor que os Deputados, o Desembargador João Pereira Ramos, o P. M. Fr. Manoel do Cenaculo e o P. M. Fr. Ignacio de S. Caetano, vendo a Pastoral manuscrita, datada de 8 de Novembro proximo passado, que o Bispo de Coimbra, D. Miguel da Annun-

(1) VIII, 8.

(2) A sentença constitui excelente contributo para melhor se entender o espirito da Reforma. 


\section{Miguel da Anunciação}

ciação, espalhou clandestinamente pelos Parocos da sua Dieceze; e ponderando o conteúdo nella, venhão relatar a esta Meza o que acharem no exame que nella fizeram. Meza, 9 de Dezembro de 1768. Arcebispo, Kegedor, Presidente. Coelho. Vasconcellos. Pereira. Gama.

\section{SENHOR}

O espírito e a letra da Pastoral do Bispo de Coimbra Dom Miguel da Annunciação, que V. Mag. ${ }^{\circ}$, por Portaria deste Tribunal, expedida em nove do corrente mez de Dezembro, foi servido mandar-nos examinar e relatar em plena Meza o que nella achassemos, contem humas copias identicas das originaes maquinaçoens que os denominados Jezuitas accumularão nesta Corte contra o Senhor Rey Dom Affon-

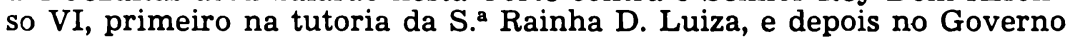
do mesmo Senhor Rey Dom Affonso. Achando-se os ditos originaes manifestos ao publico, nas Divizioens X e XI da primeira Parte da Deducção Chronologica e Analytica, e vendo-se alli, com distinta clareza, que as maquinaçoens nellas conteudas consistirão substancialmente: Primo, no estratagema de escandecer as imaginaçoens dos povos com suggestoens e exhortaçoens pateticas compostas de expressoens eccleziasticas, tão pias no modo como dolozas na substancia; secundo, no outro estratagema de inventarem e diffundirem calumnias infamatorias contra a real pessoa e govèrno do dito Senhor, suppondo e fingindo para isso, factos que nunca havião existido; tertio, no outro estratagema de espalharem declamaçoens sinistras pelos que illudiaõ nos pulpitos e nos confessionarios, de que o Reino estava perdido e os vassalos delle arruinados, de sorte, que ao mesmo tempo em que, por huma parte, tudo o que então se via com os olhos corporaes e o que se percebia com as luzes da razão, erão batalhas ganhadas nas fronteiras do Reino, por hum gloriozo exercito, aprestos e provimentos consideraveis de armadas navaes, restauraçoens de Estados nos Dominios Ultramarinos, opulentas carregaçoens de importantes mercadorias, que delles se transportavão para enriquecerem este Reino; tudo o que pela outra se ouvia aos ditos calumniadores e maquinadores, erão imagens tristes de infortunios e desgraças, que não havião succedido, prognosticos e temores funestos e vaons, armados no ar da malicia dos que os inventarão e embustes espirituaes ordenados ao fim de concitarem e fazerem grassar o fanatismo. Isto hé identicamente o mesmo que agora intentarão e pertenderão effectuar o Bispo de Coimbra e os seus suggestores e sequazes, pelo meio da sobredita Pastoral. Sendo as quatro columnas que sustentão as Monarquias, as armas, as letras, o commercio e agricultura, que V. Mag.` achou arruinadas e cahidas; e sendo notorio até ás mais pequenas pessoas da plebe destes Reinos que, depois dos gloriozos dias do Senhor Rey Dom Manoel até agora, se naó virão em Portugal, nem o exercito e marinha e arsenaes da Coroa tão poderozos; nem os Estudos publicos tão sabia e fertilmente cultivados; nem o negocio interno e a navegação mercantil dos Dominios do Ultramar tão florescentes; nem as lavouras do Continente e da America tão favorecidas e fecundas; nem a prosperidade geral de todo o Reino tão manifesta e tão brilhante aos olhos do Mundo. Contra todos estes claros e decizivos factos, intentavão prevalecer, o dito Bispo e seus sequazes, seguindo aquelles maus exemplos que imitarão e atacando descaradamente as referidas evidencias, com o libello diffamatorio da sobredita, rebelde, sedicioza e infame Pastoral que, mal lhes pareceu que poderião fazer valer pelo meio do fanatismo, que consta haverem procurado fazer grassar com outros artificios, sem advertirem na differença das circunstancias que há, entre o prezente seculo illuminado 
e o outro seculo escuro, em que os embustes dos ditos denominados Jesuitas fizerão tantos e tão horrorozos estragos. Isto, hé o que, antes de entrar nos merecimentos da dita Pastoral, se manifesta claramente e em proprios e expressos termos do Preambulo della, pelas dolozas expressoens de que o Bispo, «attendendo á obrigação indispensavel de guardar o Deposito que Deos lhe commetteu, achando-se afflicto por ver semear a zizania entre o bom trigo dos Dogmas da Fé, que se devia oppor, como muro, á torrente de doutrinas varias e peregrinas, que se tem derramado, com prejuizo immenso das almas e das consciencias; que as obras das trevas que prohibia, contém muitas proposiçoens contrarias á pureza da Fé e á santidade da Lei; que são corruptas e corruptoras da Religião, da disciplina, da piedade e capazes de introduzir a abominação, no lugar santo que hé a Igreja, etc.». Expressoens manifestamente falsas e affectadas, no mesmo espirito jezuiıco, para enganarem os pequenos, que não passão da superficie á substancia das coizas, diffundindo entre elles hum libello diffamatorio, armado na supposição de factos que nunca existirão, porque os livros libertinos que tomou por pretexto a dita Pastoral, todos se achavão prohibidos pela Meza Censoria, como se vera logo; e os dois livros de Luiz Elias Du Pin e Justino Febronio, que fizerão os dois determinados objectos do referido Bispo, tratão sómente de pontos de mera disciplina arbitraria e de pontos de jurisdição que em nada interessão os Dogmas da Fé ou a Lei e Religião, como com artificioza e mal inventada impostura se quiz persuadir. Passando, pois ,aos merecimentos da dita Pastoral, prohibe o Bispo alguns poucos livros de escritores materialistas e libertinos e, junto a estes temerarios e prejudiciaes auctores, colloca o respeitavel e ortodoxo Du Pin, nas Dissertaçoens Historicas da Antiga Disciplina da Igreja, e o sabio Justino Febronio, porque o segue, comprehendendo a todos debaixo de huma mesma qualificação vaga, violenta e contradictoria. Prohibe igualmente o uzo de todos estes livros na sua Dioceze e acautela, por meio da negação da absolvição sacramental, que não se leião aquellas obras, sem licença legitima. $\mathbf{E}$, havendo nós considerado muito maduramente a natureza deste escrito, publicado em hum tempo, tão critico como hé o prezente, no qual os Jezuitas (dispoticamente dominantes na Curia de Roma) por cartas e papéis furtivamente espalhados pelos encubertos emissarios que tem introduzido em todas as Cortes da Europa Catholica Romana, procurárão, procurão e tem conseguido alienar diversos Prelados Diocezanos, das suas obrigações, para tentarem, de acordo com a mesma Curia, todos os meios de sustentarem as reprovadas maximas da Bulla da Cea, dos Indices Expurgatorios e de todos os principios ultramontanos; tentativas, de que neste Reino ateestarão já bem claramente os Breves Apostolicum pascendi, Animarum saluti e outros similhantes escritos; e os que derão assumpto em Hespanha á temeraria e sedicioza carta do Bispo de Cuenca; e, em França, ás cartas e papéis com que diversos Pastores Sagrados tem procurado dividir sediciozamente os espiritos daquella vasta e illuminada Monarquia. Ponderando a analogia, ou antes, identidade, que as malicias da mesma Pastoral tem, com as malicias praticadas neste Reino contra o Senhor Rey Dom Affonso, na forma assima ponderada; e considerando com reflexão tudo o referido, não podemos deixar de entender que a dita Pastoral, assim na substancia como no modo della, hé obra dos Jezuitas, e que constitui hum dos insultos mais atrozes que tem chegado á real prezença de V: Mag.`, porque, não podendo nem devendo nós julgar dos interiores do Bispo, rezervados a Deos, o que se prezenta por modo authentico na dita Pastoral, hé o corpo de hum delicto de rebelião notoria, e de outro delicto de sedição manifesta. Por quanto, a Pasto- 


\section{Miguel da Anunciação}

ral, em todo o seu contexto, respira o artificio e malicia jezuitica, pela forma com que está minutada; pelos pretextos falsos e affectados; pela fraze capcioza; pelo atrevimento inaudito e calumniozo de insultar e pôr de má fé na Religião os auctores e as pessoas de sãa e muito louvavel doutrina; e pela temeridade de querer sustentar as maximas ultramontanas, prejudiciaes ao socego publico, com as quaes se achão concentrados os mesmos Jezuitas, para os seus interessses, buscados por meios illicitos, indecentes e dolozos, quaes são a calumnia, a desobediencia, o engano da gente simples e a sublevação dos Povos. O caracter do Preambulo da Pastoral hé fazer soar vozes pateticas, vagas e geraes, de que a Religião está em perigo, de que padece e está gravada, sem que estas generalidades se possão contrahir a facto algum que, ou exista ou se perceba pelos sentidos corporaes, porque nunca houve neste Reino, nem mais Religião na Corte, nem mais exemplar zelo e observancia della, não só nos Tribunaes e Magistrados, mas nem mais sizudeza e compostura de costumes na Nobreza e pessoas notaveis, como hé a todos manifesto. Donde se conclue que o dito Preambulo foi marcado ao cunho dos mesmos Jezuitas, porque este hé o distinctivo do seu caracter, em todas as suas obras desta natureza, isto hé, pertender obrigar os Povos a que creão as vozes vagas das calumnias que elles espalhão em similhantes papéis, contra a notoriedade dos factos que todo o mundo está prezenciando. Temeridade, de que se não mostrará exemplo algum, em outras ordens ou classes de pessoas, porque hé privativo estratagema dos mesmos Jezuitas. Com estes insidiozos arbitrios hé que o Bispo publicou a Pastoral, cuja malicia se demonstra, porque, sendo tantos e tão assinalados os escritores libertinos, que os Expurgatorios de todas as Naçoens e da Meza Censoria tem prohibido, elle, Bispo, se coangustou áquelles, poucos no numero, e taes na graduação que constitue a infima plebe dos ditos libertinos. Donde se conclue que os taes livros que fingio prejudiciaes no Bispado de Coimbra, sendo nelle, geral e inteiramente desconhecidos, só servirão para nelles e com elles embrulhar Du Pin, e Justino Febronio, que são os que mais pungem a Curia de Roma, porque nem os pode declarar por hereges, nem mostrar nelles propozição alguma que implique com os Dogmas. Atrevendo-se o Bispo a fazer esta escandaloza mistura de escritores materialistas e libertinos, com os sabios e catholicos $\mathrm{Du}$ Pin e Febronio, para injuriar a estes recommendaveis homens, e para injuriar a quantos adoptão as suas sans e importantes doutrinas; entregando-os desta forma á fatua decizão dos obstinados e ao escandalo dos simplices, quando vissem que apparecião igualmente comprehendidos debaixo das mesmas exprobaçoens, Du Pin, Febronio e os Filozofos dignos de justa reprovação. Donde, outra vez se conclue que a dita Pastoral foi nascida em Roma, e adoptada e espalhada por officios dos seus emissarios, pelo temerario fanatismo do disgraçado Bispo. Confirmando-se, por este modo, a affectação e impostura, com que o mesmo Bispo affirmou que os referidos livros que elle prohibio (depois de vedados pela Meza Censoria), tinhão feito estrago nos seus diocezanos; porque hé de notoriedade publica que, se no dito Bispado se pronunciarem as palavras Voltaire, Rousseau etc., perguntarão os mesmos diocezanos se são mineraes ou vegetaveis; se são viventes terrestres ou aquaticos, porque no Bispado de Coimbra não ouvirão nunca pronunciar taes nomes. Esta animozidade, pois, do Bispo, praticada por este sediciozo e affectado modo, nos conduz a reputalla por hum insulto de rebelião e de sedição formal. Se o dito Bispo houvesse espalhado 


\section{O Marquês de Pombal}

a mesma Pastoral antes da solemne publicação da piissima, e sapientissima Lei de dois de Abril deste prezente anno, em que V. Mag. prohibindo a Bulla chamada da Cea do Senhor e as que fizerão as bazes dos Indices Expurgatorios, e os mesmos Indices, mandou observar todas as Leis, Decretos, rezoluçoens e ordens respectivas á censura dos livros, prohibindo V. Mag. litteralmente na referida Lei, que alguma pessoa, de qualquer estado ou condição que seja, «possa imprimir, vender, distribuir ou, por qualquer modo, publicar nestes Reinos, ou reter nas suas Livrarias e Cartorios, nem a referida Bulla intitulada da Cea do Senhor, nem as que servirão de bazes aos Indices Expurgatorios, nem os sobreditos Indices Expurgatorios, nem outras quaesquer Bullas, depois delles introduzidas, para prohibir livros, sem preceder á publicação dellas o regio beneplacito, nem outro algum livro, ou quaderno que trate da referida Bulla da Cea, Expurgatorios, Prohibiçoens, principal ou incidentemente. Prohibido V. Mag. ${ }^{\circ}$ tambem litteralmente que, em qualquer tribunal, juizo, auditorio ou lugar dos seus Reinos e seus Dominios, ou se possão tornar a tomar, por fundamentos de votos, allegaçoens ou sentenças, as sobreditas Bullas da Cea ou Indices Expurgatorios, ou ainda os mesmos Indices e prohibiçoens supervenientes a elles para, com ellas ou com elles, se pertenderem abuzivamente confundir os sobreditos Direitos, Leis patrias, assentos de Cortes, antigos e louvaveis costumes e Concordatas, que estabelecêrão a independencia temporal desta Coroa e a reputação e o socego publico dos seus fiéis vassalos»; ordenando que nenhuma pessoa ou pessoas, de qualquer estado, ou condição que sejão, dentro nos mesmos Reynos e seus Dominios, tornem a aconselhar, allegar ou sentenciar o contrario do que, pelos sobreditos direitos, assentos de Cortes, Leis Patrias, antigos e louvaveis costumes e Concordatas foi determinado, assentado, concordado e estabelecido para a segurança do Throno e socego publico desta Monarquia e dos vassalos destes Reinos; e mandando V. Mag. ${ }^{\circ}$, sobre as referidas dispoziçoens que, todas as pessoas dos mesmos Reinos e Dominios, de qualquer estado e condição que sejão, que nelles se affastarem da pontual e exata observancia do que deixa assima ordenado, incorrão nas penas, a saber, da real e grave indignação; da confiscação de todos os seus bens para a Camera Real; da privação da naturalidade que tiveram nestes seus Reinos e seus Dominios, para mais não gozarem das honras e utilidades de que gozão os vassalos delles; e das mais penas, que pelas Leys de V. Mag..$^{\circ}$ se achão estabelecidas contra os que conspirão, ou para as offensas da real Magestade ou para as ruinas dos seus Reinos e Estados, ou para as perturbaçoens do publico socego, executando-se, irremissivel e cumulativamente, as sobreditas penas, contra os transgressores da mesma Lei, em todos ou cada hum dos cazos nella determinados, sem que seja necessario que todos elles concorrão copulativamente. Se a mesma Pastoral houvesse sido espalhada antes da publicação da outra religiosissima e providentissima Lei de sinco do mesmo mez de Abril proximo precedente, pela qual V. Mag. ${ }^{\circ}$ com os indispensaveis motivos, substanciados no proemio della, uzando, aos ditos respeitos, de todo o pleno e supremo poder que, na temporalidade, recebeo immediatamente de Deos Todo Poderozo, em justa e necessaria defeza, assim da mesma Igreja e seus Canones, de que hé protector nos seus Reinos e Dominios, e da sua real auctoridade, como da reputação, honras, vidas, fazendas e publico socego dos seus fieis vassalos, quiz, mandou, ordenou e foi sua vontade que, nesta sua Corte e Cidade de Lisboa, fosse logo creada e erigida, como por aquella foi servido crear e erigir, huma Junta perpetua denominada Real Meza Censoria, mandou que a mesma Meza tenha jurisdição privativa e excluziva, em tudo o que pertence ao exame, approvação e 


\section{Miguel da Anuncią̧ão}

reprovação dos livros e papeis que já se achão introduzidos nestes Reinos e seus Dominios; dos livros e papeis que nelles entrarem de novo, ou seja pelos portos do mar, ou pelas raias seccas; dos livros e papeis que se pertenderem reimprimir, posto que antes fossem estampados com licenças; dos livros e papeis de nova compozição; de todas as Concluzoens que se houverem de defender publicamente, em qualquer lugar destes Reinos; e de tudo o mais que pertence á estampa, impressão, officinas, venda e commercio dos sobreditos livros, e papeis. Se o dito Bispo houvesse espalhado aquella Pastoral, antes de haver sahido á luz, a segunda parte da Deduç̧ão Chronologica e Analytica, que manifestou, por modo innegavel, nas primeiras quatro demonstraçoens, que não pode haver prohibião externa de livros e papeis pela Igreja, sem não pode haver prohibição externa de livros e papeis pela Igreja, sem o consentimento e autoridade do Principe Soberano, que manifestou na demonstração quinta que este era o direito e a pratica de todas as Cortes Catholicas Romanas, mais pias e ortodoxas que manifestou, na demonstração sexta, que este era e hé o mesmo direito deste Reino, estabelecendo-se a observancia delle em quarenta e dois documentos, superiores a toda a tergiversação. Se a referida Pastoral houvesse sido espalhada antes de haverem precedido a sobredita Deducção que illuminou a todo o Mundo e foi remettida, pela Secretaria de Estado, ao mesmo Bispo, para desterrar do seu espirito, todas as suggestoens com que houvessem preocupado; e as duas Leis que o inhibirão e obrigárão, como vassalo natural deste Reino - ainda neste figurado cazo haveria commetido, contra os mais sagrados direitos de todos os Soberanos e da Coroa de V. Mag. ${ }^{\circ}$, não só a disforme uzurpação que concluem as referidas leis e demonstraçoens da dita Deducção Chronologica e Analytica, mas tambem o sediciozo attentado que, como se estivesse vendo a dita Pastoral, descreveo no lugar copiado, o doutissimo De Real na Demonstração quinta, da parte segunda da mesma Deducção, debaixo do $\S 3$, nas palavras seguintes: «Os Bispos, os Summos Pontifices, os Concilios podem indicar-nos os livros que a nossa piedade nos pode impedir que leamos; e Nós não poderiamos respeitar nunca demaziadamente aquellas advertencias dos nossos Padres espirituaes»; mas, nem elles tem alguma auctoridade coactiva, nem o Clero algum direito, para nos impedir a lição dos livros que nos parecerem bons, havendo sido publicados com auctoridade do Soberano. Dizer, por exemplo, a hum homem de Estado, a um politico e a qualquer cidadão: «Vós não podeis ler esta obra, sem encarregares a vossa consciencia, se para isso não tendes huma licença do Papa, ou dos seus Ministros», hé o mesmo que dizer-lhe: aVós não deveis crer sobre a sciencia do Governo, senão o que o Papa quer que vós creais. Absurdo que arruina, pelos seus fundamentos, todos os principios do Governo». Todo o Mundo sabe que poucos livros bons se escreverão sobre esta materia, os quaes se não achem metidos no Index. Tambem são publicas as differenças que há sempre, entre os Summos Pontifices e os Principes seculares. E, claramente se vê que, estabelecer a concluzão de que, para se conhecerem os direitos dos Principes, era necessaria a aprovação dos Papas, hé o mesmo que fazer os justos direitos dos Soberanos, dependentes das vontades dos seus inimigos. Se o Papa pudesse, por exemplo, constituir-se juiz dos livros escritos sobre ambas as jurisdicçoens, espiritual e temporal, censuraria á sua vontade, todas as obras que em si contém as nossas mais certas maximas; tirania aos cidadoens, com a publicação dos mesmos livros, o meio de se instruirem nos direitos incontestaveis da sua Patria; entregaria aos Eccleziasticos menos instruidos e mais apaixonados pelos seus interesses, a consciencia dos povos, para se lhe prohibir, no confessionario, o uzo dos mesmos livros, como 


\section{O Marquês de Pombal}

injuriozos á Santa Sede apostolica e hereticos». Se a sobredita Pastoral fosse expedida antes da outra Lei de seis de Maio de mil sete centos e sessenta e sinco, que já tinha prohibido a communicação e dispersão de quaisquer papeis, quadernos ou livros, antes de preceder o regio beneplacito, poderia, em taes termos, affectar o dito Bispo alguma desculpa. Porem, como elle fez espalhar a dita Pastoral, depois de passarem pela Chancellaria e serem publicadas, em todo este Reino, as sobreditas Leis, não fica lugar algum para desculpa, mas antes se deve reputar incurso no crime de rebellião e sedição formal, em que incorrem os que se oppoem á authoridade legislativa de V. Mag.", pois que o Bispo desprezou, desenganadamente, as Leis sacrosantas e solemnes, a cuja observancia hé obrigado, como cidadão e como eccleziastico, desviando-se assim, dos exemplos de humildade que nos deixárão os Padres da Igreja primitiva, obedientissimos ás leis dos Soberanos, como meio necessario para a tranquilidade dos Povos, da qual obediencia lhes tinha sido exemplar, Christo Senhor nosso, modelo de verdadeira piedade, á qual não se conformou a devoção inquieta e altiva deste mal consultado Prelado, concitando, por este modo, com vão pretexto da Religião, aos que não sabem persuadir-se e aos que não querem convencer-s€, para se animarem com os alentos que lhes inspira a Pastoral, a manterem a odiozidade entre o Sacerdocia e o Imperio; e para não deixarem, por huma vez, de vexar quanto de si hé, com imposturas e calumnias, a todos aquelles que respeitão, e seguem a antiguidade da Igreja: o que tudo caracteriza a Pastoral, por escrito de rebelião e sedição. Hé certo, em todo o Direito, que fica incurso no horrendo crime de formal rebellião, quem se oppoem á auctoridade legislativa de V. Mag. ${ }^{\circ}$ ou seja negando-lhe o Poder, ou oppondo-se ás suas Leis, e pertendendo apartar os seus vassalos, da obediência que, pelos Direitos Natural, Divino e das Gentes, lhe devem; o que hé atacar a Magestade e a Soberania, no mais elevado do Throno, que hé o poder de legislar, sem o qual não há Soberania. E, sendo outrosim tambem certo, em todo o Direito que, quem espalha papeis tendentes a inquietar os Povos, dividillos e imprimir-lhes dictames contrarios às Leis do Soberano, para perturbar o socego e tranquilidade publica, se deve reputar sediciozo e scismatico, em todos estes crimes se mostra incurso o Prelado auctor da sobredita Pastoral, e os seus sequazes e fautores, como vamos a demonstrar nas reflexoens seguintes. Porque, primeiramente, se mostra o animo sediciozo e rebelde, com que foi concebida a dita Pastoral, para se oppor ás Leis de V. Mag. e, alienar o Sacerdocio do Imperio, confundindo e comprometendo os poderes de ambos, quando todo o objecto das illuminadas Leis de V. Mag. ${ }^{\circ}$, foi separar justamente hum do outro poder: dar a Cezar o que hé de Cezar e a Deos o que hé de Deos, que hé o unico meio de os unir e conservar em paz. Mas, não costumando os Prelados destes Reinos publicar Pastorais manuscritas, este, porque quiz legislar contra as providentissimas dispoziçoens de V. Mag. e porque sabia que este Tribunal não lhe permittiria similhante attentado, não siguio o costume dos mais Prelados, mas antes, publicou a sua Pastoral manuscripta, para inquietar os vassalos, armar huns contra os outros e levantar estendarte de divizão entre o Sacerdocio e o Imperio. O que se confirma ainda mais, com a maior evidencia porque, não costumando, em tempo algum, os Prelados deste Reino sahir com Pastoraes e Indices prohibidos de livros, nem ainda antes de se erigir o Tribunal da Inquizição, como hé patente pelo zelo succedido no tempo do Senhor Rey D. Affonso V, no qual, espalhando neste Reino, muitos exemplares dos livros de Wicleff e João Hus, os Prelados daquelle seculo, que ainda não estavão tocados das maximas ultramontanas, não só se não arrogarão a auctoridade de prohibillos 


\section{Miguel da Anunciação}

mas, muito pelo contrario, recorrerão ao doto Senhor Rey, para que elle os prohibisse. $\mathrm{E}$ agora, no tempo prezente, em que V. Mag. ${ }^{e}$ erigio este Tribunal, no qual unio os três, da Coroa, da Inquizição e do Ordinario, e a quem prıvativamente pertence a prohibição dos livros, sahio o referido Prelado com esta Pastoral, para fazer ver que desprezava as leis de $V$. Mag." e que esta Meza está inficionada com doutrinas perversas, quando hé notoria a vigilancia e actividade com que a Meza tem abolido os escritos daquelle abominavel caracter, qual hé o da irreligião, e com que trabalha por verificar quanto, pela sua repartiçao, pode concorrer para se conservarem illesos os Dogmas preciozos da nossa Fé e o amor sincero e casto da nossa Santa Igreja Catholica Romana; e quanto pode conservar o decoro nacional, pela lição dos livros que inspirem a Religião Santa, a inteireza dos costumes, a paz e o augmento das Sciencias e das Artes; aos quaes desempenhos não pode derogar nem destruir-lhes o merecimento, o impulso attentatorio deste Bispo, esquecido culpavelmente de que as doutrinas patrocinadas, determinadas e auctorizadas pelas sabias leis de V. Mag. ${ }^{\circ}$, são as doutrinas que o Evangelho manda observar e que os Apostolos praticárão e ensinárão, confirmadas pelo uso dos seculos santos, e adoptadas por homens decididamente sabios, e muito illustres em santidade, que fazem a gloria das suas idades e das suas Naçoens, aos quaes se não pode impor a nota cruel de hereges, sem se lhes fazer gravissima injuria, que só pode ser inspirada pelo espirito do fanatismo, de desobediencia e de rebellião. Fazendo-se ainda mais patentes os motivos desta indole, que de prezente agitarão o Bispo para este rompimento, pela consideração de que as Dissertaçoens de Du Pin, há muitos annos que correm, e nunca este Prelado teve a rezolução de as prohibir, mas só o fcz depois das Leis de V. Mag.", prova manifesta de que o fez em oppozição e desprezo dellas, abrindo hum exemplo perniciozissimo aos povos, a quem era obrigado a persuadir à obediencia a V. Mag. ${ }^{\circ}$, pozitivamente, por palavra e por obras, fazendo-se a forma a que se devião ajustar as suas ovelhas, não sómente por condescendencia, mas do animo, e por conviç̧ão interior, como o praticarãão os Bispos, que se devia propor por modelo e regra das suas acçoens. Porém, mais quiz dar huma lição escandaloza, como querendo persuadir aos mais Prelados, a que sahissem ao encontro das que elle quiz imaginar doutrinas e leis erradas e a que sustentassem o depozito da doutrina, pertendendo, por hum modo artificiozo e com espirito verdadeiramente proprio dos Jezuitas que, apezar das Leis de V. Mag. ${ }^{\circ}$, prevaleção as doutrinas que elles introduzirão neste Reino, e que se conservem os vassalos de V. Mag. ${ }^{e}$, nas mesmas ignorancias e fanatismos, de que V. Mag. ${ }^{\circ}$ os quiz tirar. Pois que, impugando Du Pin e Febronio, nos seus eruditissimos escritos, o abuzo das excommunhoens! a superioridade dos Papas sobre o temporal dos Reys; e a doutrina dos que quizerão affirmar que o Papa pode depor os Soberanos e eximir os vassallos, da obediencia que lhes devem; vendo o Bispo auctorizados os escritos daquelles. Sabios, pelas Leis de V. Mag. ${ }^{\text {e, }}$ rompeo o silencio de que uzara nos annos antecedentes e, depois da publicação das referidas Leis hé que se atreveo a formalizar o escrupulo, e a fazello sensivel para sua Pastoral, interessando os semidoutos e os povos rusticos, para que (supprindo pelo numero, a falta da razão, e ajudando-se de expressoens de piedade, as quaes facilmente concilião a superstição, do crescido numero dos ignorantes) podesse, deste modo ,combater as sabias e necessarias dispoziçoens de V. Mag. ${ }^{\circ}$, retribuindo com esta infiel, pessima e turbulenta correspondencia, o amor, o zelo e a diligentissima vigilancia, com que V. Mag. ${ }^{e}$ tem felicitado os seus Estados e os tem notoriamente levantado da tristissima situação em que os deixárão os 
Jesuitas, fazendo-os dignos do respeito de outras Naçoens. O que facilmente se confirma pela obvia e natural reflexão de que, havendo errado Du Pin em outros assumptos theologicos, e havendo sido censurado em muitas proposiçoens, que elle retractou solemnemente, com a docilidade que faz o caracter do homem sabio e religiozo, o Bispo omittio estes escritos de Du Pin e foi lançar mão de huma obra corrente, approvada e analoga com os sentimentos dignos da Igreja primitiva, quando os Homens Apostólicos ensinavão as maximas depuradas de projectos terrenos, e quando o fervor da mesma Igreja as sustentava para exemplo dos seculos futuros. Não se reduzindo este abuzo do Bispo, menos do que attentar contra as Leis de V. Mag. e a combater o estabelecimento desta Meza, pertendendo subtrahir-se da sua inspecção, e fazer desta sua desobediencia, hum exemplo e regra para os outros, porque em nenhum outro sentido natural se deve ou pode tomar a capcioza clauzula da dita Pastoral que diz: «Mandamos aos nossos subditos, no Espirito Santo ,e em virtude de santa obediencia, não leião nem oução ler os livros que temos declarado nesta Pastoral, não tendo aliás licença legitima para ler livros prohibidos, fugindo como de peste, de lição tão contagioza e nociva». Pois que, não havendo razão em que caiba, que os maquinadores daquella clauzula quizerão nella significar, que tenhão por licença legitima, a desta Meza, cujo desprezo e aniquilação e das Leis que a estabelecêrão, fez o substancial objecto de toda a Pastoral - necessariamente se conclue que aquella chamada licença legitima hé, no espirito da mesma clauzula, a licença da Curia de Roma, expedida sobre a suppozição da existencia dos taes Indices Expurgatorios, para os dispensarem. Acabou, emfim, o Bispo de notorio todo o veneno da Pastoral e todo o espirito e conhecida fraze jezuitica, com que foi formulada, pela ultima clauzula que diz: $\alpha \mathbf{E}$ advertimos aos Confessores, asim seculares como regulares, a obrigação de suspender, ou deferir a absolvição, no juízo sacramental, aos que repugnarem obedecer á voz de Deos, intimada nesta Pastoral, não querendo deixar de ler ou ouvir ler tão perniciozos escritos, ainda mais funestos que as letras de Urias», etc. Clauzula, a qual em si contém todas as ircunstancias do absurdo, que o douto De Real diz no lugar assima copiado: «Que arruinaria pelos seus fundamentos, todos os principios do Governo... e entregaria aos Eccleziasticos menos instruidos, e mais apaixonados pelos seus interesses, a consciencia dos Povos, para se lhes prohibir no confessionario, o uzo dos mesmos livros, como injuriozos á Santa Sede Apostolica e hereticos». E clauzula, a qual toda a força da razão e da verosimilidade estão persuadindo que foi forjada na mesma officina jezuitica de Roma, como hum ultimo esforço da desesperação dos malvados artifices que nella se empregão, fazendo-o assim ver a coherencia, ou antes, identidade deste estratagema, com os outros que, em todos os tempos, e principalmente nestes proximos annos, tem sahido da mesma officina. Entre elles se faz digno da reflexão o seguinte. Pela petição do Recurso do Procurador da Coroa de V. Mag. ', a que V. Mag. deferio pela sua sapientistima e santissima Lei de vinte e oito de Agosto de mil sete centos sessenta e sete (que forão compilladas depois da Divizão XV da Dedução Chronologica e Analytica), se fizerão notorios, por huma parte, os quazi inumeraveis disfarces da mesma natureza de que os chamados Jezuitas se servirão, em todos os tempos e lugares, para corromperem as consciencias, não só dos povos mas das pessoas de maior auctoridade, para os fins das suas quazi diabolicas maquinaçoens; e, da outra parte, o grande segredo e cautella (ao seu parecer impenetraveis) com que maquinarão e fizerão expedir, na data de dez de Novembro do anno de mil sete centos e sessenta e seis, a obrepticia e subrepticia Bulla, que principia 


\section{Miguel da Anunciação}

pelas palavras Animarum Saluti, dando-se por ella clandestina jurisdicção aos individuos da mesma Sociedade, dispersos e disfarçados com differentes vestidos, para attentarem contra a auctoridade regia de V. Mag. ${ }^{\circ}$, contra a do Santo Officio da Inquizição e contra a dos Prelados Diocesanos destes Reinos e seus Dominios; attentados, que nelles haverião sido de funestissimos effeitos, se o segredo da referida Bulla não houvesse transpirado, com providencia que pareceu especial, em tão criticas circunstancias, como erão aquellas em que foi expedida. Sendo, pois, este o mesmo identico cazo porque a Pastoral de que se trata, contém o mesmo espirito da referida Bulla, emquanto se ordenou: $10^{\circ}$, a invenenar os confessionarios, por modo clandestino, occulto e aleivozo; $2 .^{\circ}$, a uzurpar e aniquilar, assim as Leis regias, e as amplas jurisdicçoens desta Meza, em que hoje se acha privativamente unido, tudo o que pertence á censura, prohibição e estampa dos livros e papeis; não se ignorando, nem as disposiçoens que o Bispo de Coimbra teve sempre para o fanatismo, nem o maligno caracter da pessoa, em que elle tem posto toda a sua crença, nem a connexão das mesmas pessoas com Manoel de Azevedo e, por consequencia, com os outros jezuitas de Roma, depois da sabida reconciliação e reunião que entre elles houve, para fins similhantes ao de que se trata; e, não se duvidando de que, da verosimilidade $e$ inverosimilidade recebem as provas a sua maior força, nem há coiza que seja mais verosimil da substancia e do estilo da dita Pastoral, do que ser ella minutada pelos Jezuitas da Curia de Roma; nem que seja mais inverosimel, do que arrojar-se o mesmo Bispo a commetter tantos e tão atrozes crimes de Leza Magestade, sem ser a isso arrebatado pelo impulso da mesma Curia. Em segundo lugar se deve attentamente reflectir sobre o movimento perturbadissimo e o tom irregular a que se reduziria a harmonia politica, se tivesse livre passo esta Pastoral e se esta Meza não procedesse à pezada demonstração, a que a mesma Pastoral instantemente provoca. A parte indocil e de fracas luzes, do corpo literario que costuma reputar, avêssamente, e com desprezo, tudo quanto ignora, e todos aquelles pelos quaes ella hé excedida, engrossaria o seu partido, com prejuizo da Literatura e com ultraje do merecimento alheio. Os pusillanimes que começão a ser ilustrados, entrarião em perturbação; o odio literario teria mais esta occazião de refinar; os rudes temerião; os teimozos continuarião a obstinar-se; os confessores imprudentes e ignorantes, passarião a fazer odioza a confissão, maltratando os penitentes com interrogaçoens intempestivas e querendo regular as consciencias pela sua ignorancia, auctorizada com esta imprudentissima Pastoral, os povos rusticos fluctuarião sobre a obediencia a V. Mag..$^{\circ}$ ou às disposiçoens do Bispo, porque se lhes persuadia ser esta dependencia, cauza de Religião. Por meio deste sediciozo papel, se arriscava a idéa da Soberania, confundia-se o caracter de hum Poder Augusto, instituido e protegido immediatamente por Deos, enervavão-se as forças dos Direitos Naturais e Positivo e erão concitados os vassalos a se alienarem do cumprimento dos seus officios. Nesta intoleravel perturbação de coizas, aconteceria gemerem huns, infamados erradamente de hereges; e outros, armados de ignorancia e de confiada animozidade, crerem falsamente serem elles a parte sãa da Religião, divididos os povos em scismas e sedição. Porém, se nesta Meza tem V. Mag.` querido honrar, com este serviço, sugeitos illuminados de zelo e de rezolucão, não somente para sustentarem a decoração literaria dos seus felicssimos povos, mas tambem para interceptarem o progresso do erro, e de attentados desta natureza, confiamos que, sendo, como deixamos exposto, prejudicial, imprudentissima e sedicioza, a referida Pastoral, disporá a Meza sobre ella com a satisfação que pede a justiça, e que sirva de prevenção efficacissima, 
para que não se repitão similhantes desordens. João Pereira Ramos de Azeredo Coutinho. Fr. Manoel do Cenaculo. Fr. Ignacio de S. Caetano. N. B. - A 23 de Dezembro de 1768, a Mesa plena ordena que a Pastoral seja lacerada e publicamente queimada com pregão na Praça do Commercio, pelo Executor da Justiça». A pena cumpriu-se sabado, 27 de Dezembro, na presença do Dr. António Joaquim de Pina Manique.

Aqui deixamos expresso o nosso reconhecimento à Senhora D. Lígia Brandão, dedicada Técnica Superior Principal do Arquivo da Universidade, ao Senhor Cónego Dr. António Brito Cardoso, Arquivista do Seminário Maior de Coimbra, e ao Dr. Joaquim Ramos de Carvalho, Assistente da Faculdade de Letras, pelas gentilezas que tiveram para connosco na preparação de alguns textos do Apêndice Documental.

Aproveitamos para esclarecer que alguns dos documentos transcritos já foram publicados anteriormente. 